\title{
Design Strategies for Electrochemical Aptasensors for Cancer Diagnostic Devices
}

\author{
Kamila Malecka ${ }^{1}$, Edyta Mikuła ${ }^{1}$ (D) and Elena E. Ferapontova ${ }^{2, *(\mathbb{D})}$ \\ 1 Institute of Animal Reproduction and Food Research, Polish Academy of Sciences, Tuwima Str. 10, \\ 10-748 Olsztyn, Poland; k.malecka@pan.olsztyn.pl (K.M.); e.mikula@pan.olsztyn.pl (E.M.) \\ 2 Interdisciplinary Nanoscience Center (iNANO), Faculty of Science and Technology, Aarhus University, \\ Gustav Wieds Vej 14, 8000 Aarhus C, Denmark \\ * Correspondence: elena.ferapontova@inano.au.dk; Tel.: +45-87156703
}

check for

updates

Citation: Malecka, K.; Mikuła, E.; Ferapontova, E.E. Design Strategies for Electrochemical Aptasensors for Cancer Diagnostic Devices. Sensors 2021, 21, 736. https://doi.org/ $10.3390 /$ s21030736

Academic Editor: Paolo Bertoncello Received: 14 December 2020

Accepted: 18 January 2021

Published: 22 January 2021

Publisher's Note: MDPI stays neutral with regard to jurisdictional claims in published maps and institutional affiliations.

Copyright: (c) 2021 by the authors. Licensee MDPI, Basel, Switzerland. This article is an open access article distributed under the terms and conditions of the Creative Commons Attribution (CC BY) license (https:/ / creativecommons.org/licenses/by/ $4.0 /)$.

\begin{abstract}
Improved outcomes for many types of cancer achieved during recent years is due, among other factors, to the earlier detection of tumours and the greater availability of screening tests. With this, non-invasive, fast and accurate diagnostic devices for cancer diagnosis strongly improve the quality of healthcare by delivering screening results in the most cost-effective and safe way. Biosensors for cancer diagnostics exploiting aptamers offer several important advantages over traditional antibodies-based assays, such as the in-vitro aptamer production, their inexpensive and easy chemical synthesis and modification, and excellent thermal stability. On the other hand, electrochemical biosensing approaches allow sensitive, accurate and inexpensive way of sensing, due to the rapid detection with lower costs, smaller equipment size and lower power requirements. This review presents an up-to-date assessment of the recent design strategies and analytical performance of the electrochemical aptamer-based biosensors for cancer diagnosis and their future perspectives in cancer diagnostics.
\end{abstract}

Keywords: aptasensor; aptamer; cancer biomarkers; electrochemical biosensors

\section{Introduction}

Cancer is a high-mortality chronic disease and a serious public health problem. With ageing of the population, it becomes more and more common around the world. One in three can be expected to be diagnosed with cancer in our lifetimes and one in four will die of it. In 2018, 18.1 million people worldwide had cancer and 9.6 million died from the disease. By 2040, these numbers will be almost doubled, with the greatest increase in lowand middle-income countries [1].

During last decades, a pronounced improvement in cancer diagnosis and treatment has been achieved: people suffering from some of the most common forms of cancers are twice as likely to survive for at least 10 years, compared with patients diagnosed in the early 1970s [2,3]. Tremendous progress in survival ratios has been achieved with some types of cancer, which, among other factors, can be attributed to the early detection of tumours and the greater availability of screening tests. However, for certain types of cancer the survival ratios are still low (Figure 1). Most of those patients enter the healthcare system through the portal of a pathology diagnosis: most primary and recurrent diagnoses of cancer are at present based on the pathology tissue diagnoses [4]; that also means that most cancers are diagnosed too late or are misdiagnosed, which prevents successful treatment. The five-year survival rate for cancer of the pancreas is just $6 \%$; for oesophageal cancer it is $13 \%$; and for lung cancer it is $16 \%$, which can be related to poorer early diagnosis of tumours [5] (Figure 1). Aggressive types of breast cancer, oesophagus, and liver cancers are also characterised by low five-year-survival rates, less than $20 \%$ [6], and more advanced precision medicine approaches, including early-stage and precise diagnosis of patient's specific cancer, are required for their successful treatment. 


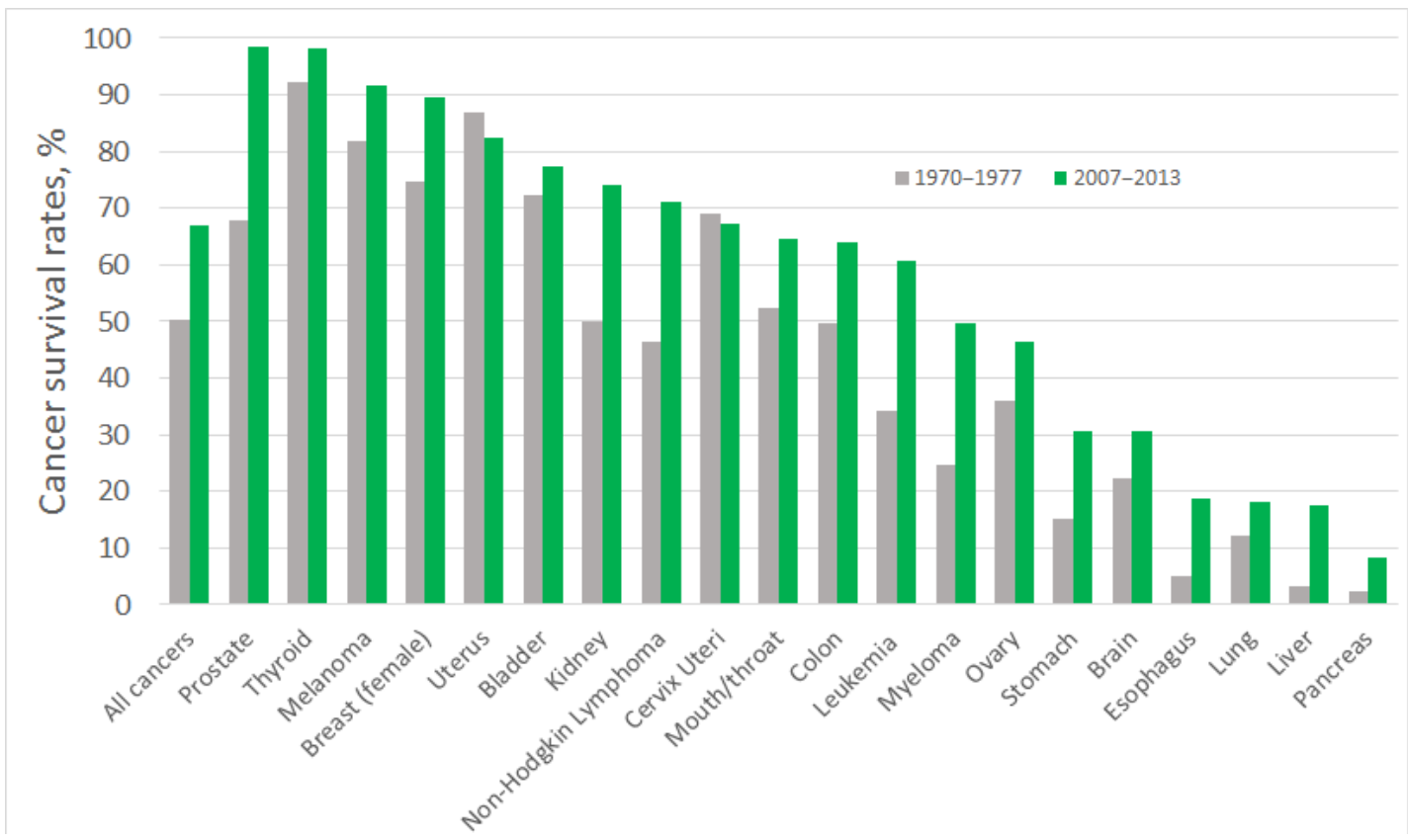

Figure 1. Five-year cancer survival rates in the USA, shown as the rate over the period 1970-1977 (grey bars) and 2007-2013 (green bars). The five-year interval indicates the percentage of people who live longer than five years following the diagnosis, data were taken from [7].

It is therefore clear that one of the most important factors in the fight against cancer is its early and reliable diagnosis: any cancer is easier to treat when the treatment is started early. The efforts are concentrated on the development of robust and non-invasive tools for early diagnosis and prognosis of cancer and its timely therapy and treatment monitoring. Liquid biopsy assays allow such a non-invasive assessment of specific tumour biomarkers via a conventional blood draw [8], and sensitive and robust biomarkers for liquid biopsybased tumour diagnosis and efficient methods for their analysis are currently one of the most challenging problems in cancer diagnosis research.

The molecular recognition elements capable of strong and selective binding of such cancer biomarkers as blood-, urine-, and saliva-circulating proteins are the most important components of such assays, providing both their high specificity and sensitivity. Among those, nucleic acid and peptide aptamers are highly attractive molecular recognition elements that can bind their targets, from small molecules to cells, with high affinity and specificity $[9,10]$. Unlike antibodies, DNA and RNA aptamers can be produced in vitro by the procedure termed Systematic Evolution of Ligands by Exponential Enrichment (SELEX) [11]. Due to their nucleic acid nature, they are amenable to chemical synthesis, which facilitates their production and extends their modification possibilities [12]. For successful operation in biological matrices, the aptamer selection is also performed in the natural environment in which they are planned to be used, in order to ensure the optimum binding properties of the aptamers in clinical samples [13]. The aptamers can be also readily engineered into bi-specific dimer aptamers $[14,15]$. Construction of "multivalent" aptamers, dimers in their simplest form, capable of binding to multiple protein binding sites, essentially improves the biorecognition and affinity properties of the aptamers. Of particular advantage for their use in sensors is that aptamers can be easily modified for any surface immobilisation and engineered to be highly stable and active $[16,17]$ (Figure 2). 
A

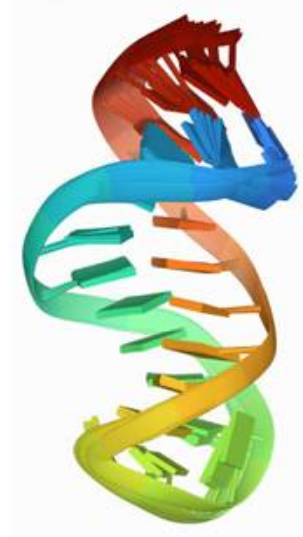

B

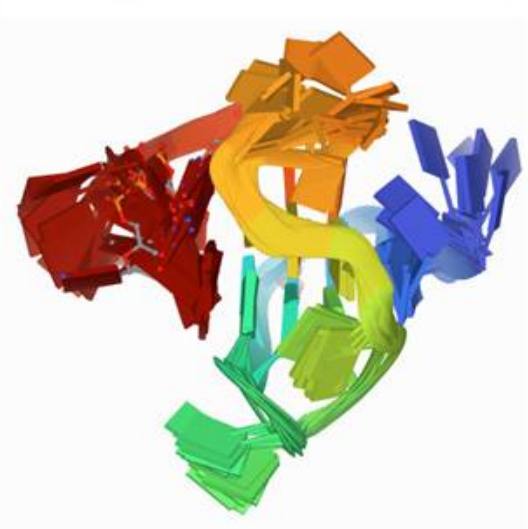

C

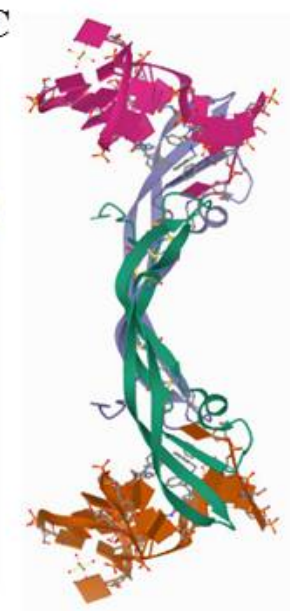

Figure 2. Structure of (A) a truncated 23-mer DNA MUC1 aptamer, image from the RCSB PDB (rcsb.org) of PDB ID 2L5K [18], (B) a VEGF aptamer with locked nucleic acid modifications, image from the RCSB PDB (rcsb.org) of PDB ID 2M53 [19], (C) human PDGF-BB protein in a complex with a modified nucleotide aptamer, image from the RCSB PDB (rcsb.org) of PDB ID 4HQU [20].

Peptide aptamers emerged later than the nucleic acid aptamers, pioneered by thioredoxin A (TrxA) affinity protein reported in 1996 [10] and defined, by analogy with nucleic acid aptamers, as a "peptide aptamer." The peptide aptamers are chosen from combinatorial libraries for their protein affinity properties and may be produced by expression in bacterial cells [21,22]. Hitherto, the peptide aptamers are rarely used in cancer diagnostic devices and thus are excluded from the scope of this review. Further the term "aptamer" will be used here only in connection with the nucleic acids aptamers, except for one example of an aptasensor for vascular endothelial growth factor detection based on a peptide aptamer [23].

As alternatives to antibodies, aptamers are currently intensively used in design of novel biosensing principles [12]. Their advantageous characteristics such as higher or comparable target affinity, long-term stability, lower batch-to-batch variation, lower preparation cost and low immunogenicity [24,25] make them most attractive biorecognition molecules in the biosensor development [26]. They can also excellently distinguish between different modified forms and isoforms of the same protein, and their affinities can be finely tuned by manipulating their binding reaction conditions and their sequence compositions [27]. Because of the convenience of their chemical modification, conjugation and redox labelling, and controlled immobilisation [27-29], the aptamers represent almost the ideal biorecognition molecules for the electrochemical biosensor design [12,30-32]. The main trends and recent advances in the electrochemical aptasensor research for cancer diagnosis are scrutinised and critically discussed in this review.

\section{Electrochemical Techniques}

In the electrochemical biosensor approach scrutinised further, the electrode is a transducer element. Electrical changes induced by the protein binding to the biorecognition interface can result either from reduction or oxidation reactions of a redox marker or due to interfacial changes and thus are analysed in several ways, such as via measuring the current or potential responses when processes involving production or consumption of electrons are involved. When such changes are not caused by direct electron flow, the measured responses are resistance, capacitance, or impedance. Generally, converting a biological interaction into an electrical signal is straightforward and can be measured and quantified by a variety of methods such as potentiometry, amperometry, voltammetry, conductometry, and impedance [33]. 
In chronoamperometry, most commonly used in biosensors, direct current is measured by applying a constant potential to the bio-modified working electrode. The amperometric response changes after the analyte binding and that allows to quantify it [34]; the response is produced either by the redox indicator or the analyte itself, if it is electroactive or conditionally can undergo a redox transformation [34]. The current response is a measure of the electron transfer rate and is proportional to the concentration of the analyte $[35,36]$.

Voltammetric methods, such as cyclic (CV), pulse differential (DPV), alternating current (ACV), linear (LSV), and stripping voltammetry, etc., are other mainstream techniques used in biosensors due to their high sensitivity, precision, accuracy, and informativity; they relate the current response from the redox markers to the potential applied [37]. The redox peak potentials are specific to the analysed system, and the magnitude of the peak current is proportional to the concentration of the analyte both if it is redox-active or if the proper redox markers are used. Voltammetric techniques are versatile and allow easy extraction of characteristic information about the analyte. CV is regularly used for determination of formal potentials, redox process mechanisms, and electron transfer kinetics [38]. The DPV and square wave voltammetry (SWV) detections have become widely applied in biosensors in recent years due to their higher sensitivity, and, as a result, selectivity. In particular, SWV is often used in fast analytical protocols, due to its ability to operate at high frequencies [39], which can also minimise the consumption of electroactive species in comparison to other pulse techniques [40]. The square wave frequency is a parameter that arises from the application of the square wave on the staircase potential and is the frequency at which the analyte is sampled. Similar to $C V$, the increment in the SWV sweep rate also correlates with an increase in the peak current, however, unlike CV, this will be proportional to the logarithm of the square wave frequency [41].

Electrochemical impedance spectroscopy (EIS) is another technique heavily exploited in biosensor research, and most productive in detecting the interfacial changes of electrodes functionalised with a biological material [42]. In EIS, a sinusoidal voltage is applied and the resulting current is measured. Impedance is then calculated as a ratio of voltage to current in the frequency domain. During analyte biorecognition and binding, the resistance and capacitance of an electric double-layer change cause variation in the impedance. By using small amplitude sine wave perturbation, linearity in electrochemical systems can be assumed, allowing the frequency analysis. EIS is further classified as a Faradaic or non-Faradaic EIS depending on the presence or absence of the redox indicator. The second one is more attractive due to no reagents being needed. Thus, the biorecognition process and label-free interactions on the sensor surface can be detected [36].

Recently, field effect transistors (FET), which are electronic semiconductor-based devices in which current flows are controlled by the applied electric field, started to populate the biosensor field. Depending on the type of the FET system, a p-type or n-type correlating with the type of their charge carriers, either positively or negatively charged analyte species can be sensitively detected by following the change in the conductance response. Novel nanotransducer designs (nanoparticles, nanotubes, nanowires, etc.) combined with biomolecule modifications demonstrate impressive sensitivity results, though the stability and sometimes selectivity of the bio-FET sensors may still be an issue [43].

\section{Electrochemical Aptasensors}

All biosensors can be classified according to the type of a signal transmitted, and are divided into electrochemical, acoustic, optical, and thermal/calorimetric biosensors $[44,45]$. Thermal biosensors measure the changes in temperature in the reaction between, for example, an enzyme and its analyte substrate. This change in temperature is then correlated with the amount of reactants consumed or products formed [46]. Resonant and acoustic wave biosensors operate by analyzing such measurand as a modulation in the physical properties of the acoustic wave that can then be correlated with the amount of the adsorbed analyte. These devices can also be miniaturised to get advantages in terms of size, scalability, and cost, and be easily integrated with microfluidics and electronics for multiplex detection 
across arrays of several devices implemented in a single chip [47]. Despite numerous reports, they have not yet found applications in clinical practice.

Optical detection biosensors are the most diverse class of biosensors exploiting many different spectroscopy techniques, such as UV-vis absorption, phosphorescence, luminescence or fluorescence. Of those, the most established commercial optical approach for protein analysis is the enzyme-linked immunosorbent assay: ELISA [48,49]. ELISA kits for specific protein cancer biomarkers are validated and widely used in clinical diagnostics of cancer; however, in some cases, they do not provide the sought sensitivity or specificity of analysis, which stimulates the search of advanced biosensor approaches [50]. Another popular type of optical biosensors is based on surface plasmon resonance and use the evanescent-wave phenomenon to describe interactions between receptors immobilised on the biosensor surface and ligands in solution. Binding of the analyte proteins by the surface-immobilised receptors alters the refractive index of the medium near the surface and this change is measured in real time to accurately estimate the amount of bound analyte, its affinity for the receptor and the dissociation and association kinetics of the interaction [51]. Despite many commercial devices offered on the market, due to their cost and often insufficient sensitivity they are not yet used in clinical practice.

Electrochemical transducers are also frequently used in biosensor research for the detection of cancer biomarkers, due to the advantages of their easy production, costeffectiveness, and user-friendliness [44,49]. Electrochemical biosensors evaluate the current or potential response resulting from either the analyte binding (capacitive changes) or an oxidation and reduction reaction at the electrode surface. Of those, electrochemiluminescence (ECL) combining the electrogenerated chemiluminescent signal amplification with an optical read out allows improving the sensitivities of immunoassays and is currently used for clinical antibody-based analysis of a number of important analytes, including tumor biomarkers. Commercially available ECL analysers, among which is Roche cobas ${ }^{\circledR} 6000$, are quite efficient with their 170 to 2170 test $\mathrm{h}^{-1}$ [52], however, they may not be suitable for direct point-of-care testing (POCT). Similarly to optical ELISAs, they need a complex equipment for assay performance. Nevertheless, electrochemical detection schemes allow easy miniaturisation of the devices and production of portable devices, and here we will consider only this type of transducers.

Combined with the aptamers, sensitive, accurate, and inexpensive electroanalytical approaches allow rapid bioanalyte detection with lower costs, smaller equipment size, and lower power requirements; they are easily adaptable for POCT by minimally trained personal [32,53]. Simple and robust electroanalytical schemes for specific and sensitive analysis of physiological-fluid-circulating protein biomarkers of cancer can support both prognosis of cancers and continuous monitoring of individual responses to cancer treatment therapies [54]. However, despite a large number of publications on the aptamer-based sensors, the majority of them are focused on just a few aptamer applications (almost 60\% of all publications deal with only eight aptamers) [22,55], while the universal strategies for the aptamer applications in electrochemical bioassays are scarce. In the case of antibodies, the universal protocols have been much better established nowadays [56]. With each new aptamer-protein ligand couple, there is a need of a systematic research of their binding behaviour, conditions and structure of complexes formed, and, not the least, their interfacial behaviour [22].

In this context, the appropriate strategy for the aptamer immobilisation on the electrodes and other assay-related surfaces is crucial for the successful biosensor development. The choice of the immobilisation protocol strongly depends both on the physicochemical properties of the electrode surface and on the aptamer modifications. The ideal electrode material should enable the surface attachment of the aptamer in a controllable way, ensuring a strong and stable binding of the aptamer to the surface altogether with its conformational flexibility necessary for specific biorecognition of the targeted analyte [57]. The immobilisation protocol should also minimise a non-specific adsorption of matrix components and ensure the sensitive detection of the analyte. One of the important issues 
to be addressed in the protein aptasensor design is electrode surface fouling by blood serum and other biological fluid proteins: the non-specific interfacial adsorption often produces strong false positive signals even in the absence of the targeted proteins [58].

Aptamers can be assembled onto solid surfaces by several approaches that are very similar to those hitherto applied for immobilisation of single- or double-stranded DNA molecules [59-61]. Most common are physical adsorption, chemisorption, covalent attachment, and affinity interactions, such as avidin-biotin binding (Figure 3). Physical absorption of nucleic acid aptamers promoted by electrostatic interactions is the simplest strategy, which simultaneously results in the unsatisfactory stability of the electrostatically immobilised aptamers due to the relatively fast aptamer desorption [62] unless additional stabilisation of binding, e.g., to gold electrodes via thiol linkers, is used [63]. Aptamer self-assembly through chemisorption of the thiol linker-modified aptamers onto the gold surface is possibly the most popular approach, despite its suffering from insufficient long-term stability [64]. Typically, the alkanethiol-linker functionalised aptamers are self-assembled on gold electrodes through the sulphur-gold linkage complemented by filling the unblocked spaces/pinholes in the self-assembled monolayers (SAM) formed by the aptamers with alkanethiols $[65,66]$, dithiols $[67,68]$ or antifouling agents $[69,70]$.

(A)

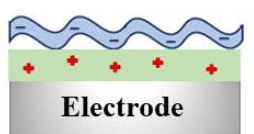

(B)

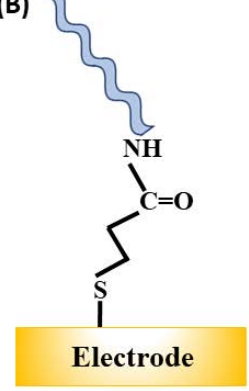

(C)

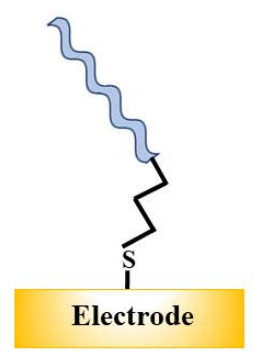

(D)

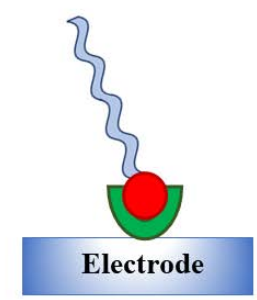

Figure 3. Immobilisation strategies for the aptasensor construction: (a) Physical adsorption of, e.g., negatively charged aptamer on the positively charged surface (e.g., polymer modified); (b) covalent attachment through the EDC/NHS ((1-ethyl-3-(3-dimethylaminopropyl)carbodiimide/Nhydroxysuccinimide) coupling between $\mathrm{COOH}$-functionalised electrode surface and the amineterminated aptamer sequence; (c) chemisorption on gold through the alkanethiol linker; and (d) through affinity (streptavidin-biotin) interactions.

The most stable immobilisation is achieved through the affinity binding between the biotinylated aptamer sequence and avidin- [71], streptavidin- [72] or neutravidin-modified electrodes [73]. Each streptavidin and neutravidin molecule, possessing four biotin-binding sites, can bind up to two biotinylated aptamers (not all binding sites are accessible for reaction due to steric restrictions induced by these proteins adsorption on electrodes), which increases the number of aptamers on the sensor surface. It also reduces the nonspecific protein adsorption and improves the sensor's signal-to-noise $(\mathrm{S} / \mathrm{N})$ ratio [74]. For covalent bonds formation, the aptamers are correspondingly modified to react with the electrode surface functionalities [75].

Chemisorption, covalent binding, as well as chemical affinity interactions are most promising approaches of aptamers deposition due to the possibility of the aptamer onepoint attachment to the electrode surface. However, the process of creating a covalent bond is quite complex and requires modification with appropriate functional groups of the electrode surface, aptamer sequence, or both. Table 1 summarises and compares the methods of aptamer deposition on solid surfaces [76,77]. 
Table 1. Comparison of the methods of aptamers deposition on solid surfaces [76,77].

\begin{tabular}{|c|c|c|c|}
\hline $\begin{array}{c}\text { Immobilisation } \\
\text { Strategy }\end{array}$ & Type of Interaction & Advantages & Disadvantages \\
\hline $\begin{array}{l}\text { Electrostatic } \\
\text { adsorption }\end{array}$ & $\begin{array}{l}\text { negatively charged aptamer } \\
\text { on the positively charged } \\
\text { surface }\end{array}$ & $\begin{array}{ll}\text { - } & \text { fast, } \\
\text { - } & \text { simple, } \\
\text { - } & \text { low-cost method }\end{array}$ & $\begin{array}{l}\text { - low packing density and } \\
\text { control of orientation, } \\
\text { random orientation of } \\
\text { the aptamer causing } \\
\text { layer instability under } \\
\text { various conditions, such } \\
\text { as changing the ionic } \\
\text { strength of the buffer, } \\
\text { pH, or other reagents, } \\
\text { - } \quad \text { non-specific adsorption, } \\
\text { low binding capacity } \\
\text { and operational stability }\end{array}$ \\
\hline Covalent attachment & $\begin{array}{l}\text { EDC/NHS coupling between } \\
\text { COOH-functionalised } \\
\text { electrode surface and the } \\
\text { amine-terminated aptamer } \\
\text { sequence }\end{array}$ & \multirow{2}{*}{$\begin{array}{l}\text { - } \quad \text { stability (bond can be broken } \\
\text { under extreme conditions), } \\
\text { - } \quad \text { well-ordered layer, } \\
\text { high degree of orientation control } \\
\text { and thickness of electrode surface, } \\
\text { single-point attachment of the } \\
\text { probe at the thiol group end-point }\end{array}$} & \multirow[t]{2}{*}{$\begin{array}{l}\text { difficult preparation } \\
\text { method, } \\
\text { - } \text { high cost }\end{array}$} \\
\hline Chemisorption & $\begin{array}{l}\text { involves chemical bond } \\
\text { between the probe and the } \\
\text { electrode surface, e.g., gold } \\
\text { through the alkanethiol linker }\end{array}$ & & \\
\hline $\begin{array}{l}\text { Affinity } \\
\text { interaction }\end{array}$ & $\begin{array}{l}\text { specific interactions such as } \\
\text { those between biotin and } \\
\text { avidin or streptavidin }\end{array}$ & $\begin{array}{l}\text { - } \quad \text { appreciable orientation, } \\
\text { - } \quad \text { stable, well-ordered layer, } \\
\text { high functionalisation through } \\
\text { specificity and sufficient control }\end{array}$ & $\begin{array}{l}\text { - } \quad \text { expensive biocompatible } \\
\text { linkers and sticky ends } \\
\text { modifications }\end{array}$ \\
\hline
\end{tabular}

The overall design of the biorecognition interface is always aimed at improving the sensitivity and the selectivity of the constructed aptasensor by a variety of signal amplification methodologies including regulating dimensionality, atomic arrangement and appropriate compositions of a sensing layer [78]. Electrocatalytic signal amplification approaches exploit enzymatic catalysis, electrocatalysis, and functional nanomaterials that can effectively enhance the aptasensor response by improving the interfacial conductivity and simultaneously diminishing the $S / N$ ratio [79]. The latter usually requires a multistep surface modification. Such nanomaterials as silica and noble metal ( $\mathrm{Au}, \mathrm{Ag}, \mathrm{Pt}, \mathrm{Pd})$ nanoparticles (NPs), graphene oxide (GO), and carbon nanotubes and their nanocomposites and nanohybrids, polymers and metal ( $\mathrm{Zn}, \mathrm{Zr}, \mathrm{Ce}, \mathrm{Hf}, \mathrm{Gd}, \mathrm{Sn}, \mathrm{Mn}, \mathrm{Fe}$ ) oxides are actively used in the electrochemical aptasensor construction [80-89]. Electrochemical nanomaterial-based aptasensors are numerously reported in biomedical research [90-93] and may satisfy a huge demand for portable analytical devices with the selectivity and specificity sufficient for healthcare applications, such as POCT of biomarkers for chronic and emerging diseases: cancer, neurodegenerative disorders, cardiovascular diseases and chronic respiratory infections [94]. The unique properties of the aptamers stimulate the further development of innovative principles of such electrochemical aptasensor operation $[95,96]$, and currently the electrochemical aptasensor-related articles represent ca. $28 \%$ of the total number of publications on electrochemical biosensors [94]. However, despite the huge progress, electrochemical aptasensors have not yet entered the market [97].

Below, we discuss the selected examples of electrochemical aptasensors for the most important protein biomarkers of cancer and their suitability for biomedical assays. 


\section{Electrochemical Assays for Cancer Biomarkers}

\subsection{Cancer Biomarkers}

The National Cancer Institute (NCI) defines "biomarker" as "a biological molecule found in blood, other body fluids, or tissues that is a sign of a normal or abnormal process, or of a condition or disease. A biomarker may be used to see how well the body responds to a treatment for a disease or condition. Also called molecular marker and signature molecule" [98]. Cancer tumour biomarkers are of uttermost practical value in cancer screening, diagnosis, and evaluation of the effectiveness of anti-cancer therapies. They indicate the presence of malignancy or provide information about the likely future behaviour of cancer (i.e., the likeliness of progression or a response to therapy). In asymptomatic patients, tumour biomarkers can be used in screening tests for the early detection of malignant tumours. In symptomatic patients, biomarkers may help in the differential diagnosis of benign and malignant neoplastic lesions. After diagnosis and surgical removal of the neoplasm, analysis of biomarkers can allow assessing prognosis, postoperative observation, treatment prediction, and monitoring the response to systemic therapy [99].

Emerging and existing electrochemical aptaassays for tumour biomarkers are becoming an indispensable tool in precision medicine research. Due to their ultra-sensitivity, high selectivity, fast signal reading and simplicity, the electrochemical aptasensors may be the most suitable candidates for cancer theranostics. They are also ideally suited for POCT since they are inexpensive and easy to miniaturise and mass-produce. The following sections concentrate on the most representative examples of the developed electrochemical aptasensors for specific protein biomarkers of cancer: Human Epidermal growth factor Receptor-2; Urokinase Plasminogen Activator; Osteopontin; Mucin 1; Carcinoma antigen 125; Vascular Endothelial growth factor; Prostate-specific antigen; Platelet-derived growth factors; $\alpha$-Fetoprotein and Carcinoembryonic antigen.

\subsection{Human Epidermal Growth Factor Receptor-2}

Human Epidermal growth factor Receptor-2 (HER-2/neu) is a $185 \mathrm{kDa}$ glycoprotein complex associated with the receptor tyrosine kinase family. HER-2/neu's overexpression occurs in several aggressive types of breast, oesophagus, and lung cancers that are characterised by the particularly aggressive growth and spreading of tumours [100]. Poor prognosis of these tumours and the necessity of their targeted therapeutical treatment require a continuous monitoring of the HER-2/neu state in response to the anticancer cure. All clinical methods for HER-2/neu detection rely on solid tumour biopsies and their PCR-based and FISH assaying $[101,102]$ and are poorly suited for continuous HER$2 /$ neu monitoring.

Liquid biopsy analysis of HER-2/neu in cancer patients' samples may be a possible alternative to solid tumour analysis: HER-2/neu released into the bloodstream by tumour cells has a huge biomarker potential to account for tumour heterogeneity compared to tissue biopsies. Several ELISA kits exploiting a sandwich assay construction exist on the market, for research purposes only, whose sensitivity and selectivity may be insufficient for precise determination of HER-2/neu at clinically requested, from $10^{-11}$ to $10^{-10} \mathrm{M}$ HER-2/neu, serum levels (with a cancer cut-off at $2 \times 10^{-10} \mathrm{M}$ ) [102].

A number of electrochemical liquid biopsy approaches were reported for sensitive and specific analysis of HER-2/neu in $0.5-4 \%$ serum samples that fitted the clinically requested concentration range [103-105]. An electrochemical immunoassay with $\left[\mathrm{Fe}(\mathrm{CN})_{6}\right]^{3-/ 4-}$ as a redox indicator allowed as low as $0.01 \mathrm{ng} \mathrm{mL}^{-1}\left(1.4 \times 10^{-13} \mathrm{M}\right) \mathrm{HER}-2 /$ neu detection by differential pulse voltammetry (DPV) in 5\% serum in $35 \mathrm{~min}$ [104] (NB: $\mathrm{g} \mathrm{mL}^{-1}$ concentrations were recalculated in molar concentrations by taking into account $70 \mathrm{kDa} \mathrm{MW}$ of recombinant HER-2 / neu used in the assays development). Here, to ensure electrode's fouling resistance, antibody- and PEG-modified iron oxide nanoparticles were chemically linked to mercaptopropionic acid-modified gold nanoparticles (AuNP) electrodeposited on a gold electrode; the electrode surface was additionally blocked by bovine serum albumin (BSA). Sufficiently cumbersome bioconjugation and chemical modification protocols were 
used in the assay development, however. By using the aptamer as a biorecognition element, from $10^{-12}$ to $10^{-8}$ M HER-2/ neu could be detected in a 30 min assay in $1 \%$ serum at the aptamer-modified Au electrodes via the electrocatalytically amplified ferricyanide reduction [103]. In a biosensor design, the HER-2/neu-specific thiolated aptamer and thiolated polyethylene glycol (PEG) were co-immobilised on gold; PEG prevented both the non-specific adsorption of serum albumins and the direct discharge of ferricyanide on the electrode surface, since electrochemistry of ferricyanide is inhibited by PEG (Figure 4A). Analysis of HER-2/neu binding to the aptamer in the presence of ferricyanide and methylene blue (MB), differently bound to the aptamer and the aptamer-HER-2/neu complex, allowed the enhancement of the electrocatalytic reduction of ferricyanide electrocatalysed by MB largely electrostatically bound to the protein-aptamer complex (Figure 4A). The assay was fast and simple, though it needed fast scan voltammetry for robust analysis of HER-2/neu.

Sandwich aptamer- and immunoassays with a catalytic signal amplification can further improve both the limit of detection (LOD) and specificity of HER-2/neu analysis. A nanoparticle-based hybrid sandwich immunoassay with silver enhancement allowed $0.1 \mathrm{pg} \mathrm{mL}^{-1}\left(1.4 \times 10^{-15} \mathrm{M}\right) \mathrm{HER}-2 /$ neu detection in $4 \%$ serum in $70 \mathrm{~min}$ [105]. The protein was trapped between the antibody immobilised onto the AuNP-glassy carbon electrode (GCE) and the aptamer reporter bearing hydrazine-modified AuNPs tags (Figure 4B). The signal amplification was provided by the silver-enhancement of the reporter AuNPs followed by square wave stripping voltammetry of the metal silver formed.

A more traditional sandwich immunoassay on magnetic beads (MBs), with the alkaline phosphatase label and 1-naphtyl-phosphate substrate, detected $6 \mathrm{ng} \mathrm{mL}^{-1}\left(8.5 \times 10^{-11} \mathrm{M}\right)$ HER-2/neu in diluted serum in $2 \mathrm{~h}$; PSA and cancer antigen 125 did not interfere [106].
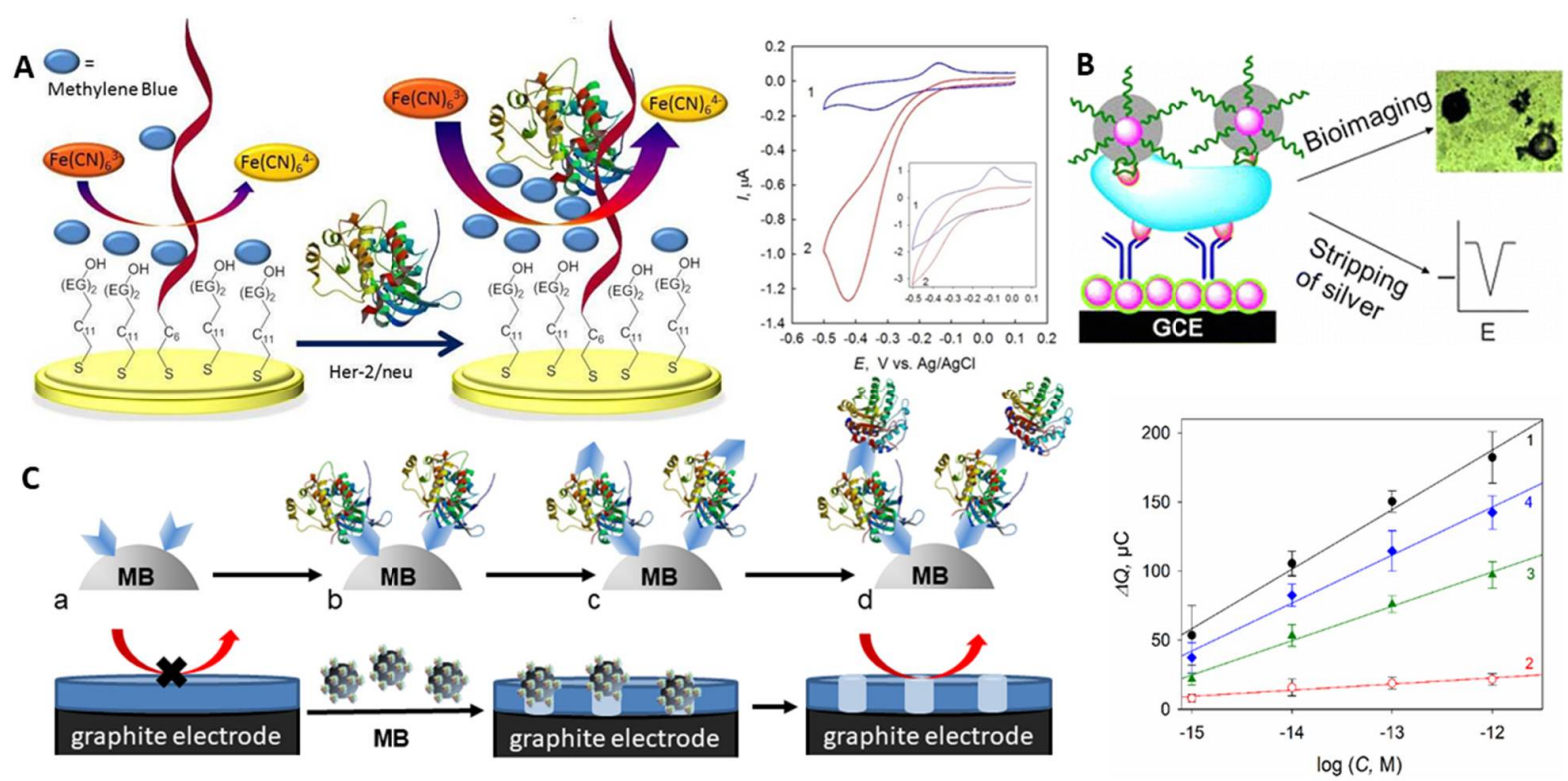

Figure 4. (A) Schematic representation of the electrocatalytic aptamer/PEG-based assay for HER-2/neu and voltammograms recorded with the aptamer/PEG-modified electrode in (1) $\mathrm{MB}$ and (2) $\mathrm{MB}$ and $\mathrm{K}_{3}\left[\mathrm{Fe}(\mathrm{CN})_{6}\right]$ solutions, scan rate $0.1 \mathrm{~V} \mathrm{~s}{ }^{-1}$ (inset: $5 \mathrm{~V} \mathrm{~s}^{-1}$ ) [103]. Specific binding sites and change of the aptamer conformation upon binding are not shown. (B) Silverenhanced hybrid sandwich immunoassay with hydrazine-modified AuNP tags [105]. (C) Cellulase-linked sandwich immunoassay on MBs modified (a) with a capture antibody or an aptamer, (b) HER-2/neu, (c) a reporter antibody or aptamer and (d) cellulase, and dependence of the sensor response on the concentration of $(1,3,4)$ HER-2/neu and (2) serum albumin for $(1,2) \mathrm{Ab}$-(protein)-Ab-MBs, (3) aptamer-(protein)-Ab-MBs, and (4) aptamer-(protein)-aptamer-MBs sandwiches [107]. Copyright (2017) Wiley, copyright (2013) American Chemical Society and copyright (2019) Elsevier, reprinted with permissions. 
The most promising performance was demonstrated by an electrochemical cellulaselinked sandwich ELISA on MBs [107]. Here, HER-2/neu was sandwiched between either antibody- or aptamer-modified MBs and antibody/aptamer reporters labelled with a non-redox active hydrolase - cellulase - an inexpensive and highly stable enzymatic label (Figure 4C). Applied onto graphite electrodes covered with an ultrathin insulating nitrocellulose film, the cellulase-labelled sandwiches digested the film. That resulted in the prominent changes in electrical properties of the electrodes, which was chronocoulometrically (CC) detected without any indicators present in solution (electrochemically label-free). Down to $1 \mathrm{fM} \mathrm{HER-2/neu} \mathrm{was} \mathrm{detected} \mathrm{in} \mathrm{whole} \mathrm{human} \mathrm{serum} \mathrm{samples} \mathrm{in}$ $<3 \mathrm{~h}$, with no interference from serum albumins or other cancer-related proteins, such as urokinase plasminogen activator protein. The best assay performance was achieved with the antibody-antibody-MBs and aptamer-antibody-MBs sandwich constructions (Figure $4 \mathrm{C}$, right panel).

\subsection{Urokinase Plasminogen Activator}

Quite recently, urokinase plasminogen activator (uPA), a $54 \mathrm{kDa}$ serine protease playing an important role in the urokinase activation system involved in cancer invasion and metastasis [108], was proposed as a universal prognostic biomarker of several cancer types $[109,110]$. Increased levels of uPA can be followed in ovarian and breast cancer, and squamous cell carcinoma, which makes uPA a valuable biomarker for liquid biopsy diagnosis of cancers [111,112]. The cancer cut-off value for this biomarker is $1.55 \times 10^{-11} \mathrm{M}$ (0.84 $\left.\mathrm{ng} \mathrm{mL}^{-1}\right)$ [113].

A 33-mer RNA sequence specific for UPA was used for construction of the aptamermodified electrodes for nM-pM analysis of uPA [114]. The RNA aptamer was stabilised against the ribonuclease digestion by its selection from the pool of fluorinated RNAs, in which fluorine substituted hydrogen in the 2 ' hydroxyl group of the ribose ring. Chemical modifications of fluorinated aptamers are expensive, and for the aptamer attachment to the Au electrode a phosphorothioated adenosine $\mathrm{dA}^{*}$ tag was introduced enzymatically into the $3^{\prime}$-end of the aptamer sequence. Nucleic acid (NA) immobilisations onto gold via the $\mathrm{dA}^{*}$ tags showed improved binding stability compared to the regular alkanethiol linkage [115] and cheapened the fluorinated RNA aptamer modification compared to the automated NA synthesis. After the aptamer tethering to gold through the $\mathrm{dA}^{*}$ linker, the surface was blocked with mercaptohexanol. The uPA binding was interrogated in two ways: at negative electrode potentials, with $\mathrm{MB}$ as a redox indicator of $\mathrm{uPA}$-aptamer binding, and at positive potentials, with ferricyanide as a solution-diffusing redox indicator sensitive to the electrode surface blocking by the formed uPA-aptamer complex. A non-specific adsorption of BSA interfered with the uPA detection at positive potentials, which resulted in $1 \mathrm{nM} \mathrm{LOD}$ insufficient for liquid biopsy analysis. With $\mathrm{MB}$, a much more specific $1 \mathrm{pM}$ analysis of uPA allowed its robust detection in serum, which resulted both from the different mechanism of the redox indicator-uPA-aptamer interactions and minimised interference from serum components [116]. The electrochemical modulation of the aptamer surface state was shown to be the key factor in optimisation of this electrochemical aptasensor response to uPA.

\subsection{Osteopontin}

Osteopontin (OPN), also known as a transformation-related protein phosphatase, is an extracellular matrix-secreted phosphorylated glycoprotein. It plays a major role in such physiological processes as bone remodelling, inflammations, immune-regulation and vascularisation. OPN is a major mediator of inflammation-a key factor in carcinogenesis with multi-functional activities [117,118]. The up-regulation of OPN expression has been identified in a variety of human cancers, including but not limited to breast [119], ovarian [120], prostate [121], and oral cavity cancers [122], lung [123], liver [124], gastric [125], pancreatic [126], and colorectal cancers [127], glioma [128], thyroid carcinoma [129], and melanoma cancer [130]. The WHO technical report identifies breast cancer as the most common cancer among women, with the highest incidence in 2018 (11.6\% of all cancers) [1]. 
Rapid detection of its potential biomarker-human OPN—offers a great promise for its rapid POCT (cancer cut-off at $8.54 \times 10^{-12} \mathrm{M}$ ) [131].

Several electrochemical aptasensors for detection of OPN have been reported. Cao and co-workers performed the OPN detection at a cucurbit[7]uril (CB[7])-functionalised pyrolytic graphite electrode. Binding of OPN to its aptamer in the test solution was followed by an exonuclease-catalysed digestion of MB-labelled DNA oligonucleotides [132]. The CB[7] molecules immobilised on the electrode captured the released MB-labelled nucleotides that accumulated on the electrode surface and subsequently yielded the voltammetric response related to the concentration of OPN. This assay combined the host-guest properties of $\mathrm{CB}[7]$ with the immobilisation-free homogeneous assay, which provided a linear response to OPN in the range from 50 to $500 \mathrm{ng} \mathrm{mL}^{-1}$ (from $7.9 \times 10^{-10} \mathrm{M}$ to $\left.7.9 \times 10^{-9} \mathrm{M}\right)$ with LOD of $10.7 \mathrm{ng} \mathrm{mL}^{-1}\left(1.7 \times 10^{-10} \mathrm{M}\right)$. OPN was assayed in 10-folddiluted human serum samples spiked with the protein [132].

A simpler aptasensor for OPN exploited ferri/ferrocyanide as a redox indicator and the affinity immobilisation of the aptamer [133]. The gold electrode was modified with 3,3-dithiodipropionic acid and its carboxylic groups were activated by EDC/NHS coupling chemistry. Then, a streptavidin layer was formed by the covalent attachment to the activated $\mathrm{COOH}$ groups, further reacting with a biotinylated 40-mer RNA aptamer. The protein binding blocked the sensor surface, and the voltammetric response from ferricyanide decreased with the increasing concentration of OPN from 25 to $2402 \mathrm{nM}$, with the signal saturation observed at $800 \mathrm{nM}$ OPN. The aptasensor showed LOD of $3.7 \mathrm{nM}$ OPN within the range reported for patients with metastatic breast cancer. This aptasensor could detect OPN in the presence of lysozyme, bovine osteopontin and BSA, however, thrombin interfered [133]. Later, the same group improved this assay by using a new biotinylated DNA aptamer [134]. The DNA-based aptasensor showed better LOD of $2.6 \mathrm{nM}$ OPN (detection by cyclic voltammetry, CV) and $1.4 \mathrm{nM}$ OPN (by square wave voltammetry, SWV) in buffer solutions. LOD of $1.3 \mathrm{nM}$ OPN detected by SWV in OPN-spiked synthetic human plasma was within the OPN plasma levels reported for patients with breast cancer (0.4-4.5 nM) and recurrent/metastatic breast cancer (0.9-8.4 nM). The results in human plasma were comparable with those obtained by ELISA. Thrombin generated current signals 2.6-10 times lower than OPN [134].

Zhou and co-workers proposed another strategy for the OPN detection based on the ferricyanide redox indicator and use of nanocomposite materials both for the aptamer immobilisation and biofouling prevention (Figure 5) [135]. The aptamer was immobilised on the nanohybrid of $\mathrm{Ti}_{3} \mathrm{C}_{2} \mathrm{~T}_{\mathrm{x}}$ MXene and phosphomolybdic acid $\left(\mathrm{PMo}_{12}\right)$ embedded within polypyrrole ( $\mathrm{PPy} @ \mathrm{Ti}_{3} \mathrm{C}_{2} \mathrm{Tx} / \mathrm{PMo}_{12}$ ). $\mathrm{PPy} @ \mathrm{Ti}_{3} \mathrm{C}_{2} \mathrm{Tx} / \mathrm{PMo}_{12}$ showed good stability and biocompatibility, and enabled a strong binding of the aptamer. Down to $0.98 \mathrm{fg} \mathrm{mL}^{-1}$ OPN was detected by electrochemical impedance spectroscopy (EIS) in the presence of $\left[\mathrm{Fe}(\mathrm{CN})_{6}\right]^{3-/ 4-}$. This aptasensor was tested in spiked human serum samples and showed low interference from thrombin, BSA, immunoglobulin G (IgG), immunoglobulin E ( $\operatorname{IgE}$ ), lysine, and prostate-specific antigen [135]. Another nanocomposite material for the aptamer anchoring, a hybrid of zirconium oxide nanoparticles and graphene-like nanofiber $\left(\mathrm{ZrO}_{2} @ \mathrm{GNF}\right.$ ), did not improve LOD (then $4.76 \mathrm{fg} \mathrm{mL}^{-1}$ or $\left.7.5 \times 10^{-17} \mathrm{M}\right)$, but allowed from $0.01 \mathrm{pg} \mathrm{mL}^{-1}$ to $2.0 \mathrm{ng} \mathrm{mL}^{-1}$ (from $1.6 \times 10^{-16} \mathrm{M}$ to $3.2 \times 10^{-11} \mathrm{M}$ ) OPN detection in spiked human plasma samples, with a negligible interference from some other cancer biomarker proteins and IgG [136]. 


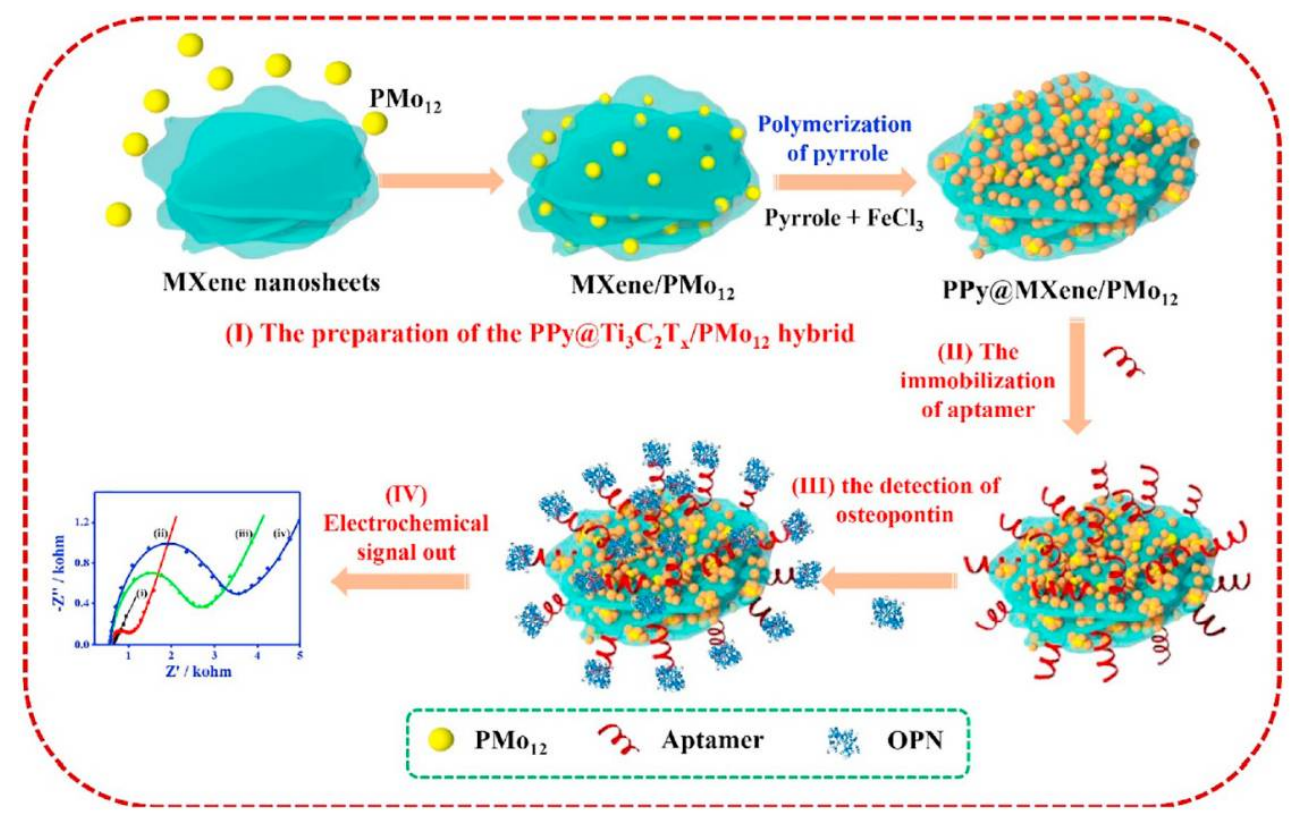

Figure 5. Schematic representation of the fabrication of the aptasensor for OPN based on the $\mathrm{PPy}_{\mathrm{C}} \mathrm{Ti}_{3} \mathrm{C}_{2} \mathrm{~T}_{\mathrm{x}} / \mathrm{PMO}_{12}$ hybrid: (I) the preparation of PPy@ $\mathrm{Ti}_{3} \mathrm{C}_{2} \mathrm{~T}_{\mathrm{x}} / \mathrm{PMo}_{12}$, (II) the aptamer immobilisation, (III) the OPN detection, and (IV) the electrochemical signal read-out [135]. Copyright (2019) Elsevier, reprinted with permission.

\subsection{Mucin 1}

Mucin 1 (MUC1, CA-15-3) belongs to the group of transmembrane glycoproteins. It is aberrantly glycosylated and overexpressed in bladder, breast, colon, lung, prostate, pancreatic, and ovarian carcinomas and is a useful biomarker for diagnosis of early cancers and evaluation of tumour-related diseases [137-139]. Being highly overexpressed in breast cancer, human MUC1 is one of the most common tumour biomarkers for this disease diagnosis [137] (the cancer cut-off level of MUC1 is $3.96 \times 10^{-12} \mathrm{M} \mathrm{[140]).} \mathrm{Unsurprisingly,}$ a large number of electrochemical aptasensors for MUC1 detection has been suggested, and some selected examples are summarised in Table 2.

One of the pioneer electrochemical aptamer assays for MUC1 is an electrochemical sandwich assay with a nanocomposite label [141]. It combined a dual signal amplification strategy of the poly(o-phenylenediamine)-AuNPs (PoPD-AuNPs) hybrid film used as a support for the aptamer immobilisation and the thionine-AuNPs-functionalised silica/multiwalled carbon nanotubes (MWCNT) core-shell nanocomposite (Thi-AuNPs $/ \mathrm{SiO}_{2}$ @MWCNTs) as a tracing label. PoPD was electropolymerised on the gold electrode surface and modified further with AuNPs and the thiolated aptamer, mercaptohexanol being used as a backfiller. After reaction with MUC1, the AuNPs-PoPD/aptamer/MUC1-modified electrodes were exposed to the aptamer/Thi-AuNPs/ $/ \mathrm{SiO}_{2} @ \mathrm{MWCNTs}$ nanoprobes to form the aptamer sandwich complex with MUC1. MUC1 was detected through the DPV response from thionine: the DPV peak currents gradually increased with MUC1 concentrations increasing from 0 to $10^{-7} \mathrm{M}$ MUC1. Under the optimised conditions, the aptasensor showed the linear dynamic range from 1 to $100 \mathrm{nM}$ and LOD of $1 \mathrm{pM}$. Carbohydrate antigens 19-9 and 72-4, carcinoembryonic antigen and BSA did not interfere with the MUC1 detection [141].

Liu and co-workers proposed another aptasensor solution based on AuNPs-related signal amplification [142]. A thiolated capture DNA probe (SH-cDNA), partially complementary to the aptamer sequence, was co-immobilised with mercaptohexanol (MCH) on the gold electrode. Next, the $\mathrm{SH}-\mathrm{cDNA} / \mathrm{MCH}$-gold surface was modified via hybridisation in two ways: (I) directly with the aptamer or (II) with the signal enhancer, the aptamerAuNPs conjugate (Apt@AuNPs). Binding of MUC1 induced the interfacial changes and, 
as a result, changed the EIS response from $\left[\mathrm{Fe}(\mathrm{CN})_{6}\right]^{3-/ 4-}$. The sensitivity of the MUC1 detection was improved with Apt@AuNPs conjugates, with LOD of $0.1 \mathrm{nM}$, and human blood serum samples were analysed by the standard addition method [142].

In another nanocomposite design, a competitive electrochemical aptasensor exploited a cDNA-ferrocene/MXene complex, in which MXene $\left(\mathrm{Ti}_{3} \mathrm{C}_{2}\right)$ nanosheets were nanocarriers for the complementary DNA-ferrocene probe ( $\mathrm{CDNA}-\mathrm{Fc}$, partially complementary to the MUC1 aptamer sequence) [143]. The sensor preparation involved three steps: (1) binding of the cDNA-Fc probe to MXene, (2) modification of AuNPs-modified GCE with the thiolated aptamer, and (3) competitive recognition of MUC1. The cDNA-Fc/MXene probe was coupled to the aptamer/AuNPs/GCE. The resulting cDNA-Fc/MXene/Apt/Au/GCE aptasensor was used for the MUC1 detection. The competitive binding reaction between the cDNA-Fc/MXene probe and MUC1 caused the release of the cDNA-Fc/MXene probe from the sensor surface. A linear relation between the detected SWV currents and the MUC1 concentration was followed for $1.0 \mathrm{pM}$ to $10 \mathrm{mM}$ MUC1, with LOD of $0.33 \mathrm{pM}$. The aptasensor detected MUC1 in human serum samples analysed by the standard addition method [143].

An even simpler in construction electrochemical aptasensor was designed using screen-printed carbon electrodes (SPCEs) modified with MWCNTs functionalised by using diazonium salt chemistry for the aptamer immobilisation and a ferricyanide redox indicator [144]. The grafted benzoic acid functional groups were further activated by EDC and reacted with the amino-terminated aptamer; in addition, the electrode was blocked by BSA to deactivate the remaining terminal groups and unreacted sites. The aptamer-MUC1 binding followed by EIS in the presence of $\left[\mathrm{Fe}(\mathrm{CN})_{6}\right]^{3-/ 4-}$ allowed down to $0.02 \mathrm{U} \mathrm{mL}^{-1}$ MUC1 detection with a linear range from 0.1 to $2.0 \mathrm{U} \mathrm{mL}^{-1}$. The aptasensor operated well in human blood serum, with negligible interferences from BSA, lysozyme, and fetal bovine serum (FBS) [90]. Immobilisation of the aptamer on the AuNPs and GO-doped poly(3,4ethylenedioxythiophene) (PEDOT) nanocomposite films electropolymerised on the surface of fluorine tin oxide (FTO) electrodes allowed further improvement of MUC1 analysis [145]. The biotinylated aptamer was immobilised via biotin-avidin linkage, and LOD of $1 \mathrm{fg} \mathrm{mL}^{-1}$ $(0.031 \mathrm{fM})$ was shown by DPV with $\left[\mathrm{Fe}(\mathrm{CN})_{6}\right]^{3-/ 4-}$. The fabricated device could determine MUC1 in spiked human serum samples with $85-93 \%$ recovery [145].

The MUC1 was also explored as a biomarker in the electronic beacon-based prostate cancer assay [146]. A thiolated DNA hairpin aptamer was conjugated to the MB redox label and immobilised onto the gold electrode via the alkanethiol linker, $\mathrm{MCH}$ being used as a co-adsorbant to backfill the pinholes and remove non-specifically adsorbed aptamer molecules. The aptasensor detected down to $0.65 \mathrm{ng} \mathrm{mL}^{-1}$ (15.9 $\mathrm{pM}$ ) MUC1 by SWV, within the $0.65-110 \mathrm{ng} \mathrm{mL}^{-1}\left(5.3 \times 10^{-12}-9.0 \times 10^{-10} \mathrm{M}\right)$ concentration range. The MUC1 production patterns were precisely determined in benign (RWPE-1) and prostate cancer cells (LNCaP and PC3), with no significant interference from ascorbic and uric acids, vascular endothelial growth factor, BSA, and prostate specific antigen [146].

Table 2. Analytical performance of selected electrochemical aptasensors for MUC1 detection.

\begin{tabular}{|c|c|c|c|c|}
\hline Strategy & Technique & LOD, M & $\begin{array}{l}\text { Interference } \\
\text { Studies }\end{array}$ & Ref. \\
\hline $\begin{array}{l}\text { POPhDA-AuNPs hybrid film/AuNPs } \\
\text { silica/MWCNT C-Sh/Au }\end{array}$ & \multirow{2}{*}{ DPV } & $1 \times 10^{-12}$ & $\begin{array}{c}\text { CEA, CA19-9, CA72-4, } \\
\text { BSA }\end{array}$ & [141] \\
\hline $\begin{array}{c}\text { ALP-strp/Apt2/Biotin/Apt1/Strp- } \\
\text { MBs/SPA }\end{array}$ & & $7 \times 10^{-11}$ & MUC4, MUC16 & [146] \\
\hline Apt-AuNPs/MCH/cDNA/Au & EIS & $10^{-10}$ & TNF- $\alpha$, CEA & [142] \\
\hline Exo I/MUC1/Apt-MB/CP/MCH/Au & SWV & $4 \times 10^{-12}$ & Myo, BSA, CEA & [147] \\
\hline Apt/EDC/MWCNT/SPCE & EIS & $0.02 \mathrm{U} \mathrm{mL}^{-1}$ & BSA, FBS, Lyz & [90] \\
\hline $\begin{array}{c}\text { Th/rGO-N }{ }^{\prime 1}, \mathrm{~N}^{\prime 3} \\
\text { DHMIA/Apt/MUC1/Apt/Pdots/IL/Au }\end{array}$ & DPV & $6 \times 10^{-11}$ & MUC4, Lys, Myo & [148] \\
\hline
\end{tabular}


Table 2. Cont.

\begin{tabular}{|c|c|c|c|c|}
\hline SH-Apt-MB/Au & SWV & $4 \times 10^{-9}$ & $\begin{array}{l}\text { AA, UA, VEGF, BSA, } \\
\text { PSA }\end{array}$ & [145] \\
\hline MB-Apt/AuNPs/GCE & DPV, EIS & $24 \times 10^{-9}$ & Lyz, BSA, Cyt C & [149] \\
\hline $\begin{array}{c}\mathrm{Apt} / \mathrm{ZrHCF} \\
\mathrm{NPs} / \mathrm{ZrHCF} / \mathrm{mFe}_{3} \mathrm{O}_{4} / \mathrm{mC} / \mathrm{Au}\end{array}$ & EIS & $\begin{array}{c}7.4 \times 10^{-15} \\
\left(0.9 \mathrm{pg} \mathrm{mL}^{-1}\right)\end{array}$ & CEA, IgG, BSA & [150] \\
\hline $\begin{array}{l}\text { AuNPs and GO doped PEDOT films } \\
\text { APT/Strp/AuNPs-GO-PEDOT }\end{array}$ & \multirow{3}{*}{ DPV } & $3.1 \times 10^{-17}$ & MPT64, AChE, BSA & [144] \\
\hline $\begin{array}{c}\text { Exo } \\
\text { I/Apt-MUC1/cDNA-MB/Naf/ITO }\end{array}$ & & $\begin{array}{l}3.3 \times 10^{-15} \mathrm{M} \\
\left(0.4 \mathrm{pg} \mathrm{mL}^{-1}\right)\end{array}$ & $\begin{array}{c}\text { CEA, GP73, HSA, ALP, } \\
\text { AFP }\end{array}$ & [151] \\
\hline $\begin{array}{c}\text { Metal ion electrochemical } \\
\text { labels } / \mathrm{Ru}\left(\mathrm{NH}_{3}\right)_{6}{ }^{3+} \text { electronic wires }\end{array}$ & & $3.33 \times 10^{-15}$ & $\begin{array}{c}\text { FBS, HCG, MUC16, } \\
\text { CA19-9 }\end{array}$ & [152] \\
\hline $\begin{array}{c}\text { AuNPs-DNA } \\
\text { enzyme/H-2/MCH/c-DNA/Au }\end{array}$ & Amp & $\begin{array}{c}3.3 \times 10^{-16} \\
\left(0.04 \mathrm{pg} \mathrm{mL}^{-1}\right)\end{array}$ & PSA, Thr, CEA, BSA & [153] \\
\hline $\begin{array}{c}\text { MXene probe/c-DNA-Fc/Apt + } \\
\text { BSA/AuNPs/GCE }\end{array}$ & SWV & $3.3 \times 10^{-13}$ & Not shown & [143] \\
\hline
\end{tabular}

Abbreviations: POPhDA—poly(o-phenylenediamine); AuNPs—gold nanoparticles; MWCNs-multi-walled carbon nanotubes; C-Shcore-shell; Au—gold electrode; ALP—alkaline phosphatase; Strp—streptavidin; Apt; Apt1; Apt2—aptamers; MBs—-magnetic beads; SPA— screen-printed arrays; MCH—6-mercaptohexan-1-ol; cDNA—capture DNA; Exo I—Exonuclease I; MB—methylene blue; MUC1; MUC4; MUC16 - transmembrane mucins; SWV_-Square Wave Voltammetry; EIS—electrochemical impedance spectroscopy; GCE-glassy carbon electrode; DPV—Differential Pulse Voltammetry; Amp—amperometry; CEA—carcinoembryonic antigen; CA19-9—carbohydrate antigen 19-9; CA72-4—cancer antigen 72-4; BSA—bovine serum albumin; TNF- $\alpha$ — tumour necrosis factor $\alpha$; Myo-myoglobin; Lyz-lysozyme; FBS-fetal bovine serum; Lys-lysine; AA — ascorbic acid; UA-uric acid; VEGF-vascular endothelial growth factor; PSA-prostate specific antigen; Cyt C—cytochrome C; IgG-Immunoglobulin G; MPT64-Mycobacterium tuberculosis; AChE-acetylcholinesterase; GP73-golgi protein 73; HSA-human serum albumin; AFP_alpha-fetoprotein; HCG-human chorionic gonadotrophin; Thr-thrombin; EDC-1-Ethyl-3-(3-dimethylaminopropyl) carbodiimide; SPCE-screen-printed carbon electrode; IL—interleukin; Pdots-polymer dots; rGO-reduced graphene oxide; DHMIA $-\mathrm{N}^{\prime 1}, \mathrm{~N}^{\prime 3}$ dihydroxymalonimidamide; Th-thionine; ZrHCF NPs-zirconium hexacyanoferrate nanoparticles; $\mathrm{mFe}_{3} \mathrm{O}_{4}$ - mesoporous $\mathrm{mFe}_{3} \mathrm{O}_{4} ; \mathrm{GO}$ - graphene oxide; PEDOT—poly(3,4-ethylenedioxythiophene); Naf-Nafion; ITOindium tin oxide electrode; H-2-hairpin 2; Fc-ferrocene; MXene-two-dimensional inorganic compounds.

\subsection{Carcinoma Antigen 125}

Carbohydrate antigen 125 (CA125), also known as mucin 16 (MUC16), is a heavily O-glycosylated protein and a component of the female reproductive tract epithelia, the respiratory tract and the ocular surface. It is aberrantly overexpressed in breast, ovarian, lung and pancreatic tumours, and thyroid cancers and plays an important role in cancer progression and metastasis [154-156]. The world's incidence of gynaecological tumours is high, with ovarian cancer being one of the most common malignancies in the female reproductive system with the highest mortality rate. In the early stage of cancer development, most patients do not show any clinical signs or symptoms, and since its discovery in 1981, CA125 has been used as a gold standard biomarker of epithelial ovarian cancer [157]. The concentration of CA125 in ovarian cancer patients' samples ranges between 5.4 to $6700 \mathrm{U} \mathrm{mL}^{-1}$, with the threshold level (the cut-off value above which the result is considered positive) at $35 \mathrm{U} \mathrm{mL}^{-1}$ [158].

Both the high incidence and mortality rate of ovarian cancer, particularly among the European female population, require robust and inexpensive liquid biopsy tests to timely diagnose this cancer, and many efforts are focused on the development of appropriate electrochemical aptasensors for the CA-125 detection.

The field-effect aptasensor detected down to $5 \times 10^{-10} \mathrm{U} \mathrm{mL}^{-1} \mathrm{CA} 125$, also in serum samples from ovarian cancer patients [159]. This flexible field-effect-transistor (FET) aptasensor was constructed by non-covalent immobilisation of carboxylated MWCNTs onto a few layers of reduced GO (rGO) nanosheets integrated with a poly-methyl methacrylate substrate; the aptamer was attached to carboxylated MWCNTs via EDC/NHS chemistry. The electrical characteristics of the constructed liquid-ion-gated FET aptasensor were followed by measuring the FET currents resulting from the protein binding. Under optimal conditions, the aptasensor showed the linear dynamic range from $10^{-9}$ to $1 \mathrm{U} \mathrm{mL}^{-1}$ of 
CA125, with negligible interference from carcinoembryonic antigen, alpha-fetoprotein, and cancer antigen 15-3 [159].

The promising electrochemical aptasensing platform was elaborated by combining the aptamer modification of SPCEs with the target-triggered strand displacement strategy (Figure 6) [160]. The thiolated DNA hairpin sequence (SH-hDNA) was immobilised onto flower-like gold nanostructures electrodeposited onto polylayers of poly(ethylene imine)/poly(acrylic acid) (PEI/PAA) layer by layer self-assembled on SPCEs. The modified SPCE surface was blocked with MCH to remove non-specifically adsorbed DNA. Further, the hybrid was formed between the DNA probe partially complementary to SH-hDNA and the CA125 aptamer and exposed to CA125 samples. CA125 binding released the DNA probe that then hybridised with the toehold of SH-hDNA. The second hairpin labelled with MB (hDNA-MB) then subsequently hybridised via its toehold domain with SH-hDNA, and the increasing SWV response from the MB label generated after these cascade reactions was linearly proportional to the CA125 concentration within the 0.05 to $50 \mathrm{ng} \mathrm{mL}^{-1}$ range $\left(5.0 \times 10^{-14}\right.$ to $\left.5.0 \times 10^{-11} \mathrm{M}\right)$. LOD was $5 \mathrm{pg} \mathrm{mL}^{-1}\left(5.0 \times 10^{-15} \mathrm{M}\right)$, and a negligible interference from BSA, PSA, CD63 and epithelial cell adhesion molecule was observed. The aptasensor could operate in CA125-spiked serum, urine and saliva [160].

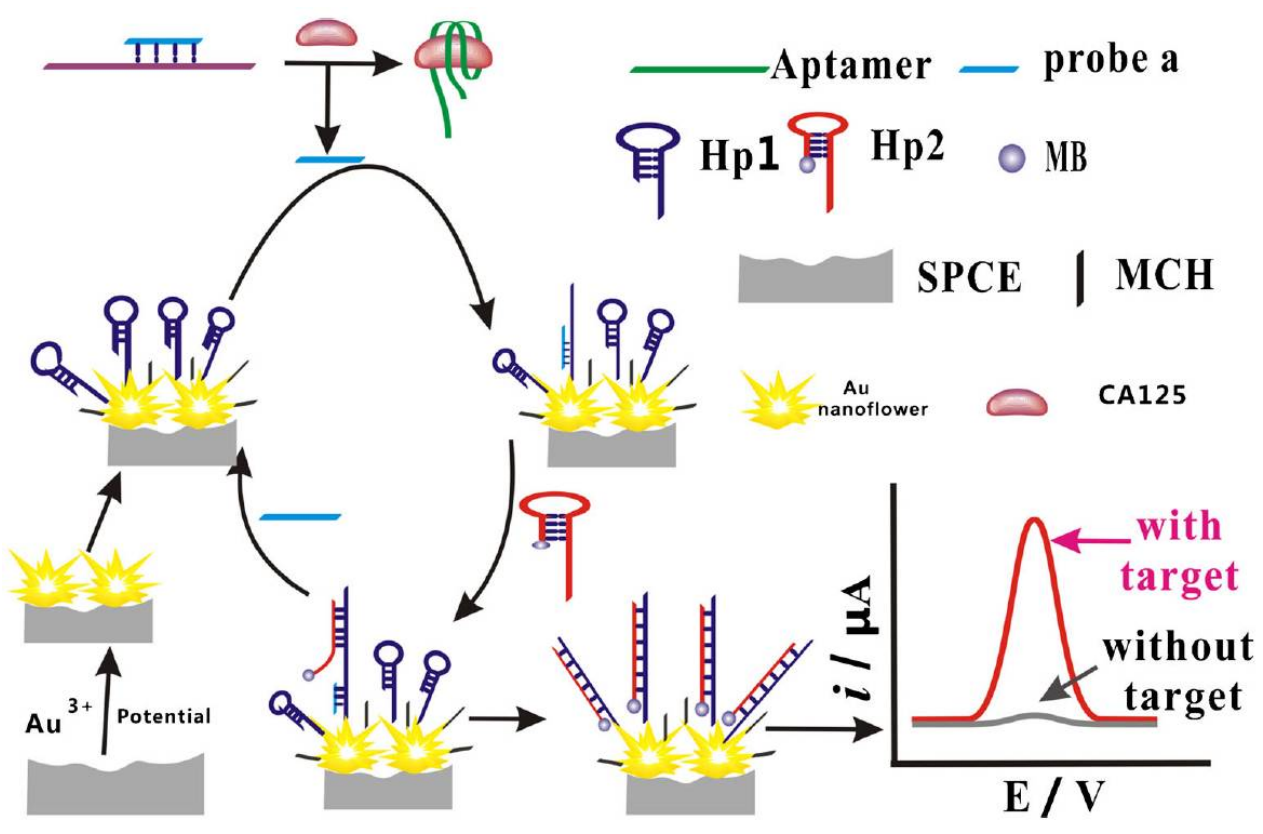

Figure 6. Schematic representation of the stepwise preparation of the biosensor for CA125 detection based on the use of flower-like gold nanostructures and target-triggered strand displacement amplification [160]. Copyright (2019) Springer, reprinted with permission.

A nanocomposite electrode modification exploiting amidoxime-modified polyacrylonitrile electrospinned nanofibers (NFs) decorated with Ag nanoparticles (AgNPs-PAN-oxime $\mathrm{NFs}$ ) allowed the $0.0042 \mathrm{U} \mathrm{mL}^{-1}$ DPV detection of CA125 and its clinical applications, such as analysis of CA125 positive and negative human serum samples comparable to ELISA [161]. In sensor construction, the indium tin oxide (ITO) electrode was covered by AgNPs-PAN NFs, chemically modified to bear amidoxime groups, to which the aminated aptamer was coupled via glutaraldehyde (GA) cross-linking. The modified electrode was blocked with BSA to prevent non-specific binding. The MB-labelled signalling-probe (sDNA) was further immobilised on the ITO/AgNPs-PAN NFs/ $\mathrm{NH}_{2}$-aptamer surface through its partial hybridisation to the aptamer. The sensor was exposed to CA125, and its recognition by the aptamer released the MB-labelled sDNA into solution. The sDNA displacement resulted in the diminishing MB peak currents detected by DPV within the 
0.01 to $350 \mathrm{U} \mathrm{mL}^{-1}$ CA125 dynamic linear range. Lysozyme, IgG, IgA, BSA and serum haemoglobin $(\mathrm{Hb})$ did not significantly influence the CA125 analysis [161].

Metal-organic frameworks (MOFs), formed by coordination bonds between metal ions and organic ligands, were shown to be a suitable platform for the aptamer immobilisation due to their good adsorption capacities [162]. Two kinds of bimetallic core-shell Tb-MOF-onFe-MOF and Fe-MOF-on-Tb-MOF nanostructures were deposited on gold electrodes, and the aptamer was immobilised on those, the Tb-MOF-on-Fe-MOF composite demonstrating the best adsorption characteristics. CA125 binding followed by EIS with $\left[\mathrm{Fe}(\mathrm{CN})_{6}\right]^{3-/ 4-}$ allowed down to $58 \mu \mathrm{U} \mathrm{mL}^{-1}$ CA125 analysis (a linear range from $0.1 \mathrm{mU} \mathrm{mL} \mathrm{mL}^{-1}$ to $200 \mathrm{U} \mathrm{mL}^{-1}$ ). The aptasensor performed well in human serum, with no interference from MUC1, carbohydrate antigen 19-9, vascular endothelial growth factor, immunoglobulin G, carcinoembryonic antigen, epidermal growth factor receptor, porcine serum albumin, and alpha-fetoprotein [162].

A hybrid aptamer-antibody sandwich assay based on the hybridisation chain reaction (HCR), with $\mathrm{MB}$ as a redox indicator, could detect $0.02 \mathrm{U} \mathrm{mL}^{-1} \mathrm{CA} 125$ in human samples [163]. The antibody/CA125/aptamer sandwich was formed by reaction of the CA125-specific antibody immobilised onto the surface of the AuNPs-modified ITO electrode with CA125, stepwise reacting with its aptamer. Then the $3^{\prime}$-end of the aptamer was subjected to HCR. DPV oxidation signals from the redox indicator intercalating into the G-C reach regions of the formed duplexes were linearly proportional to from 0.39 to $200 \mathrm{U} \mathrm{mL}^{-1}$ of CA125, and uric acid, alpha-fetoprotein, carcinoembryonic antigen and cancer antigen 153 did not interfere with the sensor response [163]. Another variant of the aptamer/CA125/antibody sandwich assay was performed on MBs [164]. COOHfunctionalities of MBs were activated in reaction with EDC and then allowed to react with CA125 monoclonal antibodies and horseradish peroxidase (HRP) as an enzymatic label. The antibody-modified MBs were used to capture the CA125 from human blood and serum samples and then collected on the aptamer-modified gold electrodes via the CA125 sandwich aptacomplex formation. HRP-labelled MBs attached to electrodes generated the bioelectrocatalytic response in the presence of its substrate $\mathrm{H}_{2} \mathrm{O}_{2}$, and CV and EIS responses to CA125 were linear for 2 to $100 \mathrm{U} \mathrm{mL}^{-1} \mathrm{CA} 125$, covering the entire clinical concentration range of serum samples [164].

\subsection{Vascular Endothelial Growth Factor}

Vascular endothelial growth factor (VEGF) is a growth factor and signalling protein involved in tumour angiogenesis by increasing the blood vessel permeability. It plays a crucial role in the endothelial cell growth, proliferation, migration, and differentiation. VEGF is considered as an important biomarker for such diseases as cancer, rheumatoid arthritis, retinopathy, and some neurodegenerative diseases, such as Parkinson's and Alzheimer's diseases. Aberrant expression of VEGF occurs in many types of cells, including cancer cells. Elevated levels of VEGF are often detected in patients with breast, lung, ovarian, thyroid, and prostate cancers [165-167].

An impressive number of electrochemical aptasensors for VEGF analysis has been reported during last five years. Table 3 summarises some representative examples focused on electroanalysis of human $\mathrm{VEGF}_{165}$ - the recombinant form of a $38.2 \mathrm{kDa}$ homodimeric glycoprotein composed of two identical 165 amino acid chains. The VEGF 165 levels in healthy people range between $60.3 \mathrm{fM}$ and $12.2 \mathrm{pM}\left(2.30\right.$ and $\left.467.10 \mathrm{pg} \mathrm{mL}^{-1}\right)$ [168], with the VEGF 165 cut-off value of $6.7 \mathrm{pM}$ (or $256 \mathrm{pg} \mathrm{mL}^{-1}$ ) in cancer patients [169].

In 2018, a comprehensive review by Dehghani and co-workers summarised the research on the electrochemical aptasensors for $\mathrm{VEGF}_{165}$ [170], and here we provide an overview of the works appeared since then. Most of them exploit different types of redox probes, including the routine ferri/ferricyanide redox indicator, FC and MB labels, and more complex redox-nanocomposite modifications.

The cucurbituril and azide co-functionalised graphene oxide $\mathrm{CB}[7]-\mathrm{N}_{3}-\mathrm{GO}$ nanocomposite linked to Fc-modified branched ethylene imine polymer (BPEI) (BPEI-Fc/CB[7]- 
$\mathrm{N}_{3}$-GO) via host-guest interactions was suggested as an electrochemical label for the VEGF $_{165}$ aptasensing [171]. The solution-formed aptamer/alkyne-DNA hybrid released the alkyne-DNA strand after reaction with $\mathrm{VEGF}_{165}$, and this alkyne-DNA reacted with the hairpin DNA immobilised on the gold electrode surface through the thiol linker. After the hybrid formation, the duplex was labelled through the "electro-click" reaction with $\mathrm{BPEI}-\mathrm{F} \mathrm{C} / \mathrm{CB}[7]-\mathrm{N}_{3}-\mathrm{GO}$ producing the change in the electrochemical response within the $2.62 \times 10^{-16}$ to $2.62 \times 10^{-11} \mathrm{M}\left(10 \mathrm{fg} \mathrm{mL}^{-1}\right.$ to $\left.1 \mathrm{ng} \mathrm{mL}^{-1}\right) \mathrm{VEGF}_{165}$ range and LOD of $2.1 \times 10^{-16} \mathrm{M}\left(8 \mathrm{fg} \mathrm{mL}^{-1}\right)$ [171].

Another nanocomposite approach used the Au-Pd alloy/EMIMPF6 ionic liquid (IL) modification of GCE as a platform for the aminated aptamer immobilisation via the glutaraldehyde coupling reaction [145]. BSA co-immobilisation combatted the non-specific binding. The DPV response from the MB redox indicator ("signal off") and the EIS response from $\left[\mathrm{Fe}\left(\mathrm{CN}_{6}\right)\right]^{3-/ 4-}$ ("signal on" assay) displayed the linear ranges of 1-150 pM and 5-200 pM, respectively, and LOD of 0.5 and $0.78 \mathrm{pM}$. The aptasensor detected $\mathrm{VEGF}_{165}$ as a lung cancer biomarker in human serum samples [172].

Gold/graphene quantum dot/thionine nanocomposite hybrid (Au/GQD) allowed even more pronounced amplification of the aptasensor response [173]. A thiolated hairpin DNA probe $\mathrm{H} 2$ ( $\mathrm{MCH}$ as a co-adsorbant) was immobilised on gold electrodes, and further the surface was modified to produce a hybrid consisting of DNA hairpin H1-Au/GQDthionine. Each VEGF 165 molecule could bound to two other DNA probes via the specific aptamer-target recognition to obtain a molecular machine that reacted/hybridised with the surface-tethered $\mathrm{H} 2$ probe through the proximity effect. The aptasensor detected down to $0.3 \mathrm{fM} \mathrm{VEGF}_{165}$, also in human serum, while the SWV signal increased linearly within the $1 \mathrm{fM}$ to $120 \mathrm{pM}$ concentration range [173].

Another impedance aptasensor exploited the ferricyanide redox indicator and a nanocomposite consisting of gold nanoarchitectures (AuNAs) embedded with nanochitosan (NChtn) for the aptamer immobilisation. It allowed a $1.77 \times 10^{-13} \mathrm{M}\left(6.77 \mathrm{pg} \mathrm{mL}^{-1}\right)$ VEGF $_{165}$ detection. The AuNAs@NChtn-based aptasensor demonstrated reasonable suitability for the $\mathrm{VEGF}_{165}$ detection in real serum samples [174].

A ratiometric aptasensor exploited two sensing biointerfaces for VEGF detection: a GO/MB redox nanocomposite either covalently attached or physically absorbed on GCE with a Fc-labelled aptamer assembled on the top. The linear range of the designed GCE-GO/MB-streptavidin/biotin-aptamer-Fc sensors was $2.62 \times 10^{-13}-1.31 \times 10^{-11} \mathrm{M}$ and $5.24 \times 10^{-13}-1.31 \times 10^{-11} \mathrm{M}\left(10-500 \mathrm{pg} \mathrm{mL}^{-1}\right.$ and $\left.20-500 \mathrm{pg} \mathrm{mL}^{-1}\right)$ VEGF for covalent and non-covalent attachment of GO/MB, respectively (Table 3) [175]. Another redox-nanocomposite aptasensor for real-time detection of VEGF in serum was based on the rGO/MB-AuNPs nanocomposite deposited on GCE, on which the mixture of SHaptamer-Fc and the thiol-modified antifouling agent-polyethylene glycol (SH-PEG) - was self-assembled [176]. The VEGF binding decreased the intensity of both $\mathrm{FC}_{\mathrm{C}}$ and MB signals due to the electrode reactions impeded by the formed VEGF/aptamer-Fc complex. The ratiometric dual signal from $\mathrm{Fc}$ and $\mathrm{MB}$ allowed LOD of $2.62 \times 10^{-15} \mathrm{M}\left(0.1 \mathrm{pg} \mathrm{mL}{ }^{-1}\right)$ and the linear range of $5.24 \times 10^{-14}$ to $1.31 \times 10^{-11} \mathrm{M}\left(2-500 \mathrm{pg} \mathrm{mL}^{-1}\right)$ VEGF [176].

Enzymatic bioconjugate labels also allowed their easy integration with the aptamer sequences. Glucose dehydrogenase (GDH) conjugated with DNA-binding protein-zinc finger protein (ZFP) — was used to label the DNA aptamer specific for VEGF by taking advantage of the sequence-specific binding ability of ZFP [177]. For the construction of the hybrid sandwich immunosensor, streptavidin was covalently attached to dithiobis(succinimidyl undecanoate) SAMs formed on a gold wire and then used for immobilisation of the biotinylated anti-VEGF antibody. VEGF binding was amperometrically detected in the presence of glucose, at 105 pM VEGF levels, after VEGF labelling with the aptamer-GDH-ZFP complex [177].

An impedance line-pad-line electrode (LPLE) aptasensor allowed label-free $0.017 \mathrm{fM}$ electroanalysis of $\mathrm{VEGF}_{165}$ [178]. Impedance responses of the aptamer-modified gold LPLE (BSA as a blocking agent) were linearly proportional to 0.026-31.4 $\mathrm{fM} \mathrm{VEGF}_{165}$ with 
insignificant interference from such proteins as thrombin, PDGF-BB; VEGF ${ }_{121}$, and human IgG [178]. These results are remarkable considering the massive efforts focused on the development of the label- (and indicator-) free approaches. Another label-free sensor for VEGF analysis in human blood exploited the complementary metal oxide semiconductor (CMOS) platform [23]. The VEGF binding by the peptide-aptamer-modified microneedles was followed by monitoring the capacitance changes between the microneedles by a two-step capacitance-to-digital converter (CDC). The aptasensor detected VEGF at its $0.1 \mathrm{pM}$ levels [23].

Table 3. Analytical performance of selected electrochemical aptasensors for $\mathrm{VEGF}_{165}$.

\begin{tabular}{|c|c|c|c|c|}
\hline Strategy & Technique & LOD, $M$ & $\begin{array}{l}\text { Interference } \\
\text { Studies }\end{array}$ & Ref. \\
\hline $\begin{array}{c}\text { Sandwich } \\
\text { Apt/MBs-Ab/VEGF/Apt/AuIDE }\end{array}$ & EIS (capacitance) & $\begin{array}{c}10.5 \times 10^{-12} \\
\left(401 \mathrm{pg} \mathrm{mL}^{-1}\right)\end{array}$ & BSA & [179] \\
\hline $\begin{array}{c}\text { NP/Strp-ALP/B-Apt/VEGF/MCH/SH- } \\
\text { Apt/AuNPs/SPGE }\end{array}$ & DPV & $3 \times 10^{-8}$ & HER2 & [180] \\
\hline $\begin{array}{c}\mathrm{MB} / \mathrm{Apt} / \mathrm{GA} / \mathrm{BSA}-\mathrm{AuNC} / \mathrm{IL} / \mathrm{GCE} \\
\mathrm{Apt} / \mathrm{GA} / \mathrm{BSA}-\mathrm{AuNCs} / \mathrm{IL} / \mathrm{GCE}\end{array}$ & $\begin{array}{c}\text { DPV } \\
\text { EIS } \\
\text { (Ferri/ferrocyanide) }\end{array}$ & $\begin{array}{l}\text { signal-off: } \\
0.32 \times 10^{-12} \\
\text { signal-on: } \\
0.48 \times 10^{-12}\end{array}$ & Not shown & [169] \\
\hline SH-Apt/OMC-Aunano $/ \mathrm{SPCE}$ & $\begin{array}{c}\text { EIS } \\
\text { (Ferri/ferrocyanide) }\end{array}$ & $\begin{array}{l}26.2 \times 10^{-15} \\
\left(1 \mathrm{pg} \mathrm{mL}^{-1}\right)\end{array}$ & $\begin{array}{l}\text { HIgG, HIgA, Lip, Lyz, } \\
\text { HSA }\end{array}$ & [181] \\
\hline Fc-Apt-alkyne/UDT + UDT-N $3 / \mathrm{Au}$ & $\mathrm{ACV}$ & $6.2 \times 10^{-9}$ & $\begin{array}{l}\text { VEGF }_{121}, \mathrm{BSA}, \mathrm{HSA}, \\
\text { trypsin }\end{array}$ & [182] \\
\hline $\begin{array}{l}\text { DNA-Ag/Pt NCs/amino-Apt/GCE } \\
\text { Peroxidase mimicking activity }\end{array}$ & Amp & $4.6 \times 10^{-12}$ & Thr, HSA, HIgG & [183] \\
\hline $\mathrm{MCH} / \mathrm{SH}-\mathrm{Apt}-\mathrm{MB} / \mathrm{Au}$ & SWV & $\begin{array}{c}3.93 \times 10^{-12} \\
\left(0.15 \mathrm{ng} \mathrm{mL}^{-1}\right)\end{array}$ & AA, UA & [184] \\
\hline Apt $/ \mathrm{Au}_{\text {nano }} / \mathrm{rGO}-\mathrm{PAMAM}-\mathrm{Th} / \mathrm{SPCE}$ & DPV & $0.7 \times 10^{-12}$ & $\begin{array}{l}\text { U, AA, D, Glu, HIgG, } \\
\text { HIgA }\end{array}$ & [185] \\
\hline $\begin{array}{c}\text { BPEI-Fc-CB[7]-N } \mathrm{N}_{3}-\mathrm{GO} / \mathrm{S} 1 / \mathrm{MCH} / \mathrm{S} 2 / \mathrm{SH}- \\
\mathrm{Apt} / \mathrm{Au}\end{array}$ & SWV & $\begin{array}{l}0.21 \times 10^{-15} \\
\left(8 \mathrm{fg} \mathrm{mL}^{-1}\right)\end{array}$ & $\begin{array}{l}\text { BSA, HSA, VEGFR1, } \\
\text { VEGFR2, VEGF } 121\end{array}$ & [171] \\
\hline $\begin{array}{c}\mathrm{MB} / \mathrm{NH}_{2}-\mathrm{Apt} / \mathrm{GA} / \mathrm{AP} / \mathrm{IL} / \mathrm{GCE} \\
\mathrm{NH}_{2} \text {-Apt/GA/AP/IL/GCE }\end{array}$ & $\begin{array}{c}\text { DPV } \\
\text { EIS } \\
\text { (Ferri/ferrocyanide) }\end{array}$ & $\begin{array}{l}\text { signal-off: } \\
0.5 \times 10^{-12} \\
\text { signal-on: } \\
0.78 \times 10^{-12}\end{array}$ & Not shown & [172] \\
\hline $\begin{array}{c}\text { Hairpin } \\
\text { DNA/AuNPs/GQD/Thi/MCH/SH- } \\
\text { hairpin } \\
\text { DNA/Au }\end{array}$ & SWV & $0.3 \times 10^{-15}$ & PSA, BSA, Thr & [173] \\
\hline $\begin{array}{l}\text { Peptide Apt-based functionalised } \\
\text { microneedles }\end{array}$ & EIS (capacitance) & $0.1 \times 10^{-12}$ & $\begin{array}{l}\text { HIgG, Con A, cholera } \\
\text { toxin }\end{array}$ & [23] \\
\hline SH-Apt/AuNAs@NC/Au & $\begin{array}{c}\text { EIS } \\
\text { (Ferri/ferrocyanide) }\end{array}$ & $\begin{array}{c}0.18 \times 10^{-12} \\
\left(6.77 \mathrm{pg} \mathrm{mL}^{-1}\right)\end{array}$ & Lyz, HIgG, CEA, PSA & [174] \\
\hline SH-Apt/LPLE & EIS & $\begin{array}{c}0.017 \times 10^{-15} \\
\left(0.64 \mathrm{fg} \mathrm{mL}^{-1}\right)\end{array}$ & $\begin{array}{l}\text { Thr, PDGF-BB; } \\
\text { VEGF }_{121}, \text { HIgG }\end{array}$ & [178] \\
\hline $\begin{array}{c}\text { Sandwich Apt-GDH/VEGF/Biotin-Ab/ } \\
\text { strp/DTBSU/AuWE }\end{array}$ & Amp & $105 \times 10^{-12}$ & BSA & [177] \\
\hline
\end{tabular}


Table 3. Cont.

\begin{tabular}{|c|c|c|c|c|}
\hline $\begin{array}{l}\text { biotin-Apt-Fc/MB-strp/GO-GCE } \\
\text { biotin-Apt-Fc/MB-strp/GO-PhA-GCE }\end{array}$ & SWV & $\begin{array}{c}2.62 \times 10^{-15} \\
(1 \mathrm{pg} \mathrm{mL}-1) \\
0.18 \times 10^{-12} \\
\left(7 \mathrm{pg} \mathrm{mL}^{-1}\right)\end{array}$ & $\begin{array}{l}\text { IL-6, CA-125, PSA, } \\
\text { HIgG }\end{array}$ & [175] \\
\hline $\begin{array}{c}\text { SH-Apt-Fc + } \\
\text { SH-PEG/AuNPs-MB/rGO-GCE }\end{array}$ & SWV & $\begin{array}{l}2.62 \times 10^{-15} \\
\left(0.1 \mathrm{pg} \mathrm{mL}^{-1}\right)\end{array}$ & HIgG, IL-1 $\beta$, PSA, IL-6 & [176] \\
\hline
\end{tabular}

Abbreviations: AuIDE-interdigitated electrodes; Apt-aptamer; MBs-magnetic beads; Ab-antibody; VEGF-vascular endothelial growth factor; SWV-Square Wave Voltammetry; EIS—electrochemical impedance spectroscopy; DPV_Differential Pulse; Amp-amperometry; NP_1-naphthyl-phosphate; Strp-ALP—streptavidin-alkaline phosphatase conjugate; B-Apt-Biotinylated Apt; AuNPs/SPGE_-Gold nanostructured graphite screen printed electrodes; GA — glutaraldehyde; BSA-AuNCs—BSA-gold nanoclusters; IL—ionic liquid; GCEglassy carbon electrode; $\mathrm{Au} / \mathrm{GQD}$-Gold/graphene quantum dot hybrid; OMC-Aunano mesoporous carbon-gold nanocomposite; HER2-human epidermal growth factor receptor 2; HIgG-human immunoglobulin G; HIgA-human immunoglobulin A; Liplipase; Lyz-lysozyme; HSA-human serum albumin; UDT-N 3 -11-Azido-1-undencanethiol; ACV-alternating current voltammetry; DNA-Ag/Pt NCs_DNA bimetallic Ag/Pt nanoclusters; Thr-human thrombin; SPCE-screen-printed carbon electrode; rGOPAMAM/ $\mathrm{Au}_{\text {nano }}$-reduced graphene oxide/gold functionalised with poly(amidoamine) dendrimers; U—urea; AA—ascorbic acid; Ddopamine; Glu-glucose; BPEI-branched ethylene imine polymer; Fc-aminomethylferrocene; CB[7]-cucurbit[7] urils macrocycle; N3GO-azide-functionalised graphene oxide; S1-alkyne-functionalised DNA strand; MCH-6-mercaptohexan-1-ol; S2-hairpin DNA strand; AP-Au-Pd alloy; IL-ionic liquid; Con A-concanavalin A; AuNAs@NC-Au nanoarchitecture embedded with nanochitosan; CEAcarcinoembryonic antigen; LPLE-label-free line-pad-line; PDGF-BB-platelet-derived growth factor-BB; GDH-glucose dehydrogenase; Amp-amperometry; Biotin-Ab_-biotinylated antibody; DTBSU_dithiobis(succinimidy undecanoate); AuWE-gold wire electrode; GO/MB - methylene blue loaded graphene oxide; PhA—physical adsorption; SH-PEG-thiol-modified polyethylene glycol; IL-6interleukin-6; PSA—prostate specific antigen; IL-1 $\beta$-interleukin-1 $\beta$.

\subsection{Prostate-Specific Antigen}

Prostate cancer is the second most frequently occurring cancer in men worldwide and the fourth most commonly occurring cancer overall. There were 1.3 million new cases in 2018 [1,186]. Early prostate cancer usually shows no clinical symptoms and, therefore, requires efficient screening tests for its early diagnosis. Prostate-specific antigen (PSA), a serine protease of 30-34 kDa produced by epithelial prostatic cells, is the main biomarker for the diagnosis, screening and monitoring of patients with prostate cancer and eventually the first tumour biomarker approved by the Food and Drug Administration (FDA) [187]. The standard PSA cut-off is $0.125 \mathrm{nM}\left(4 \mathrm{ng} \mathrm{mL}^{-1}\right)$. However, with this cut-off, only $20.5 \%$ of the prostate cancer cases are tested positively and nearly $80 \%$ of this cancer cases are missed. Prostate cancer is often suspected when the PSA concentration is in the "diagnostic grey zone" from 4 to $10 \mathrm{ng} \mathrm{mL}^{-1}$ PSA $[188,189]$.

There are clinically approved immunoassays for PSA detection [190,191] and numerous electrochemical aptasensors aiming at inexpensive and robust ways of PSA electroanalysis have been reported and intensively overviewed [192-199]. Here, we update only few very recent reports.

The aptasensor based on the hemin-functionalised graphene-conjugated palladium nanoparticles (H-Gr/PdNPs) deposited on GCE showed a linear response to PSA in the concentration range from 0.025 to $205 \mathrm{ng} \mathrm{mL}^{-1}$, with a LOD of $8 \mathrm{pg} \mathrm{mL}^{-1}$. The sensor was used for quantitation of PSA in spiked serum samples, giving recovery rates ranging from 95.0 to $100.3 \%$. Hemin acted both as a protective agent and as an in-situ redox probe. PdNPs provided numerous binding sites for immobilisation of biotinylated DNA via coordinative binding between Pd and amino groups of DNA's bases. The PSA aptamer was immobilised via biotin-streptavidin interactions [200].

In another study, the aptasensor was constructed by immobilisation of a thiolated DNA aptamer onto AuNPs/fullerene C60-chitosan-IL/MWCNT/SPCE. The aptasensor determined PSA by EIS and DPV in the range of 1 to $200 \mathrm{pg} \mathrm{mL}^{-1}$ and LOD of $0.5 \mathrm{pg} \mathrm{mL}^{-1}$ and 2.5 to $90 \mathrm{ng} \mathrm{mL}^{-1}$ and LOD of $1.5 \mathrm{ng} \mathrm{mL}^{-1}$, respectively. Analysis of the PSA in serum samples obtained from patients with prostate cancer was performed [201].

A simpler modification of SPCE with AuNPs and a thiolated aptamer combined with voltammetric analysis of signals from $\left[\mathrm{Fe}(\mathrm{CN})_{6}\right]^{3-/ 4-}$ resulted in the linear response to PSA in the concentration range from $31.3 \mathrm{fM}$ to $6.25 \mathrm{nM}\left(1 \mathrm{pg} \mathrm{mL}^{-1}\right.$ to $\left.200 \mathrm{ng} \mathrm{mL}^{-1}\right)$ PSA and LOD of $2.41 \mathrm{fM}\left(0.077 \mathrm{pg} \mathrm{mL}^{-1}\right)$ [202]. The aptasensor operated in undiluted human 
serum, with a negligible interference from BSA, IgG and $\mathrm{Hb}$, and its performance was comparable to ELISA's.

In a nanocomposite design, a thiolated aptamer was co-immobilised with $\mathrm{MCH}$ on the nanocomposite-modified GCE; a nanocomposite was: graphene quantum dots-chitosannafion-IL; MWCNTs-graphene-IL and polypyrrole- $\mathrm{MoS}_{2}$-IL-AuPt NPs [203]. Sensor's SWV responses processed by a computerised monitoring system (SACMES) linearly changed with the PSA concentration in the $15.6 \mathrm{fM}-10.9 \mathrm{pM}\left(0.5-350 \mathrm{pg} \mathrm{mL}^{-1}\right)$ range and LOD was $4.38 \mathrm{fM}\left(0.14 \mathrm{pg} \mathrm{mL}^{-1}\right)$. Neuron-Specific Enolase, $\mathrm{HSA}, \mathrm{Hb}$, thrombin, IgG and lysine did not interfere with the PSA detection, and the sensor operated well in serum [203]. A magnetic GCE modified with $\mathrm{rGO} / \mathrm{Fe}_{3} \mathrm{O}_{4} / \mathrm{Cu}_{2} \mathrm{O}$ nanosheets was used as a transducer in another nanocomposite ratiometric aptasensor, electroactive $\mathrm{Cu}_{2} \mathrm{O}$ NPs deposited onto the surface of $\mathrm{rGO} / \mathrm{Fe}_{3} \mathrm{O}_{4} \mathrm{NSs}$ acting as reference tags (Figure 7). The aptamer-modified Ag@resorcinol-formaldehyde (RF) NPs were assembled on the magnetic electrode surface. After reaction with PSA, NPs were removed from the electrode surface and then worked as electroactive Ag nanodot detection tags. Aptasensor's linear range was from $0.313 \mathrm{pM}$ to $3.13 \mathrm{nM}$ (0.01 to $\left.100 \mathrm{ng} \mathrm{mL}^{-1}\right)$ PSA, with LOD of $194 \mathrm{fM}\left(6.2 \mathrm{pg} \mathrm{mL}^{-1}\right)$. The aptasensor could operate in human serum with a low interference from $\alpha$-fetoprotein, carcionoembryonic antigen, cysteine, GSH, and tryptophan [204].

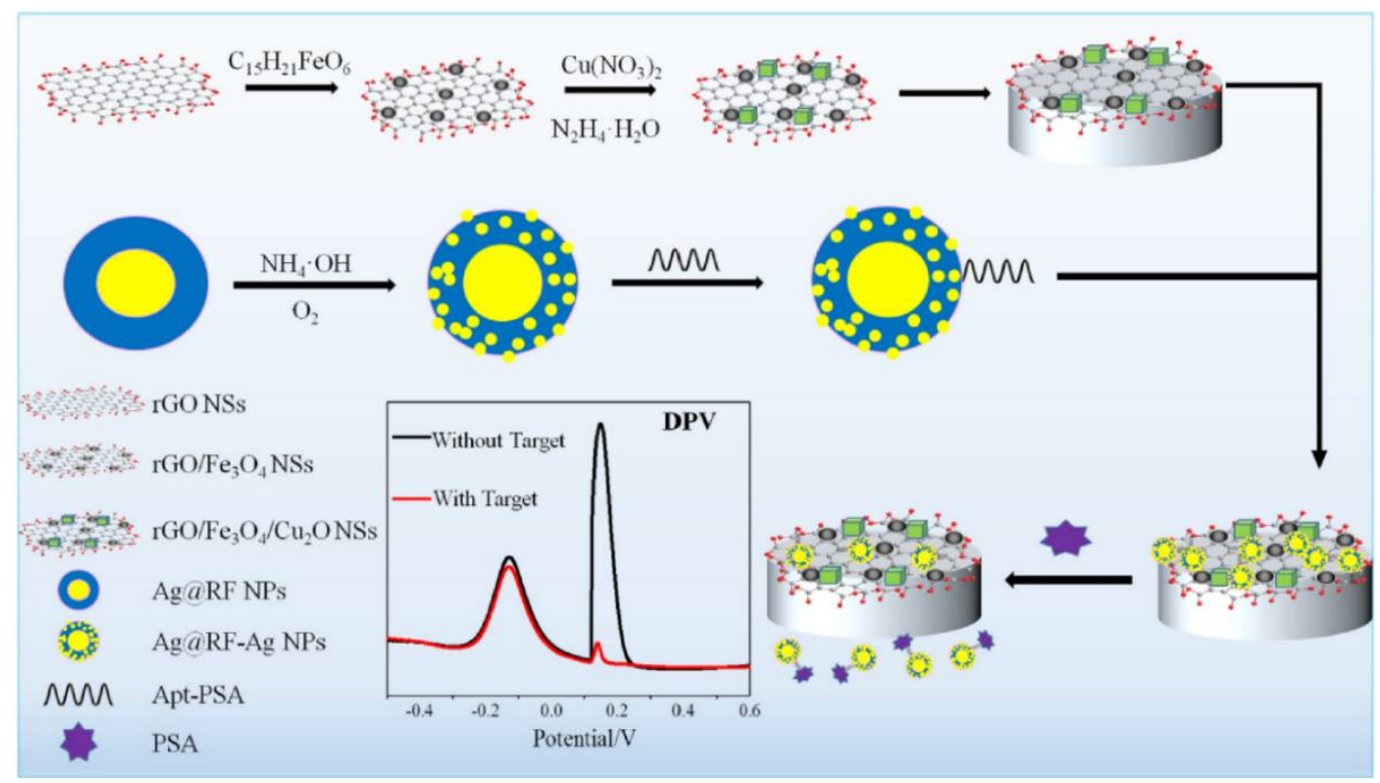

Figure 7. Schematic illustration of the electrochemical ratiometric aptamer-based assay for PSA [204]. Copyright (2020) Elsevier, reprinted with permission.

\subsection{Platelet-Derived Growth Factors}

Platelet-derived growth factors (PDGF) are disulphide-bond stabilised heterodimeric peptides existing in a number of isoforms including PDGF-AA, PDGF-BB, and PDGF-AB. Among them, PDGF-BB is a cancer-related protein. It contributes to proliferation, survival, and motility of connective tissue and some other types of cells by initiating signalling via two receptor tyrosine kinases: $\alpha$ - and $\beta$-receptors. PDGF overexpression is linked to malignancies and diseases characterised by excessive proliferation of cells, such as atherosclerosis or fibrosis. PDGF play at least three roles that can lead to the tumour growth: autocrine stimulation of cancer cells, stimulation of angiogenesis, and control of tumour interstitial pressure, and are considered as prognostic biomarkers of numerous cancers [205]. Its cancer cut-off value is $6.87 \times 10^{-11} \mathrm{M}$ [206].

Electrochemical aptamer-based biosensors for PDGF-BB were numerously reported [207]. They exploit a variety of design approaches, exemplified by sandwich assays based on 
$\mathrm{MOS}_{2}$ /carbon aerogel composites [208], aptamer-functionalised multidimensional hybrid conducting-polymer plates [209], carbon-based nanocomposites with aptamer-templated silver nanoclusters [210]. A simple in design label-free aptasensor constructed by immobilisation of a thiolated PDGF-binding aptamer and $\mathrm{MCH}$ on a gold electrode and using a $\left[\mathrm{Fe}(\mathrm{CN})_{6}\right]^{3-/ 4-}$ redox indicator linearly responded to PDGF concentrations ranging from 1 to $40 \mathrm{nM}$ (DPV analysis) [211]. Another simple approach suggested the electrochemical aptamer beacon design for the detection of PDGF biomarker directly in blood serum. Alternating current voltammetry was used to monitor interactions between MB-labelled aptamer immobilised on a gold electrode and PDGF [212]. The aptasensor detected the BB variant of PDGF at $1 \mathrm{nM}$ directly in unmodified, undiluted blood serum and at $50 \mathrm{pM}$ in serum diluted 2-fold with an aqueous buffer solution. The aptasensor was well suited for using in portable microdevices [212].

Selected examples of electrochemical aptasensors for PDGF, developed since 2015, are presented in Table 4. Here, we discuss only two most recent examples published since 2018.

In the first example, a Y-shaped DNA probe target-triggered amplification strategy was used for PDGF-BB detection in human serum [213]. A thiolated hairpin aptamer H1 coimmobilised with $\mathrm{MCH}$ on the AuNP-selenium-doped MWCNTs-graphene-modified GCE. After PDGF-BB addition, aptamer $\mathrm{H} 1$ bound with it and triggered the catalytic assembly of two other hairpin DNAs to form the G-quadruplex Y-junction DNA structures, which released PDGF-BB to bind again the intact aptamer and initiate another assembly cycle. Next, G-quadruplex/hemin complexes were formed when hemin was added; the former generated a substantially amplified current output. The DPV response of the aptasensor to PDGF-BB displayed a linear range from $0.1 \mathrm{pM}$ to $10 \mathrm{nM}$ with LOD of $27 \mathrm{fM}$. Thrombin, IgG, and PSA did not interfere [213].

In the second example, a flexible, three-dimensional carbon nanoweb (3D-CNW)based aptamer platform was designed for PDGF-BB detection [214]. Poly(acrylonitrile) nanowebs (NWs) were used as a template for the overall 3D structure. A silver paste was screen-printed on both ends of the nanowebs and subjected to the chemical vapour deposition process using the $\mathrm{Cu}$ powder. $\mathrm{Cu}$ was then etched to generate carbon bulges on the surface of the 3D-CNW. The aminated DNA aptamer and 4-(4,6-dimethoxy-1,3,5-triazin2-yl)-4-methylmorpholinium chloride) (a condensing agent) were coupled to the 3D-CNW surface of the transducer, by covalent binding between the amino group of the aptamer and the carboxyl groups of CNW. The analytical performance tested with a liquid-ion gated FET-type setup exhibited LOD of $1.78 \mathrm{fM}$, also in FBS, and the aptasensor response to PDGF was not compromised by calmodulin, adenosine triphosphate, and BSA [214].

Table 4. Analytical performance of selected electrochemical aptasensors for PDGF.

\begin{tabular}{|c|c|c|c|c|}
\hline Strategy & Technique & LOD, M & $\begin{array}{l}\text { Interference } \\
\text { Studies }\end{array}$ & Ref. \\
\hline $\begin{array}{c}\text { Sandwich assay based on } \\
\mathrm{MOS}_{2} / \text { carbon aerogel composites }\end{array}$ & DPV & $0.3 \times 10^{-12}$ & $\mathrm{BSA}, \mathrm{CEA}, \mathrm{Hb}, \mathrm{IgG}$ & [208] \\
\hline Structure-switching hairpin probe & $\mathrm{CV}$ & $\begin{array}{c}2.67 \times 10^{-12} \\
\left(0.08 \mathrm{ng} \mathrm{mL}^{-1}\right)\end{array}$ & $\begin{array}{c}\text { PDGF-AA, PDGF-AB, } \\
\text { IgG, BSA }\end{array}$ & [215] \\
\hline \multirow[t]{2}{*}{$\begin{array}{c}\text { VS2-GR coupled with Exo III-aided } \\
\text { signal amplification leaf like VS2 } \\
\text { nanosheets }\end{array}$} & DPV & $0.03 \times 10^{-12}$ & BSA, IgE, Thr, CEA & [216] \\
\hline & DPV & $0.4 \times 10^{-12}$ & $\mathrm{Hb}$, Thr, BSA & [217] \\
\hline $\begin{array}{l}\text { A background current-eliminated Apt } \\
\text { sensing platform }\end{array}$ & $\mathrm{ACV}$ & $\begin{array}{l}0.334 \times 10^{-12} \\
\left(10 \mathrm{pg} \mathrm{mL}^{-1}\right)\end{array}$ & PDGF-AA, PDGF-AB & [218] \\
\hline $\begin{array}{c}\mathrm{Fe}_{3} \mathrm{O}_{4} @ 3 \mathrm{D}-\mathrm{rGO} @ \text { plasma- } \\
\text { polymerised (4-vinyl pyridine) } \\
\text { nanocomposite }\end{array}$ & EIS & $\begin{array}{c}0.98 \times 10^{-12} \\
\left(29.4 \mathrm{pg} \mathrm{mL}^{-1}\right)\end{array}$ & Thr, IgG, Lyz, BSA & [219] \\
\hline
\end{tabular}


Table 4. Cont

\begin{tabular}{|c|c|c|c|c|}
\hline $\mathrm{Co}_{3}\left(\mathrm{PO}_{4}\right)_{2}$ BSA-based aptasensor & EIS & $\begin{array}{l}0.123 \times 10^{-12} \\
\left(3.7 \mathrm{pg} \mathrm{mL}^{-1}\right)\end{array}$ & $\begin{array}{l}\text { BSA, IgG, Lyz, Thr, } \\
\text { PDFG-AA, PDGF-AB }\end{array}$ & [220] \\
\hline $\begin{array}{c}\text { Exo III-aided signal amplification } \\
\text { strategy }\end{array}$ & DPV & $20 \times 10^{-15}$ & $\begin{array}{c}\mathrm{Hb}, \mathrm{BSA}, \mathrm{IgG}, \mathrm{CEA}, \\
\text { BSA }\end{array}$ & [221] \\
\hline Apt-functionalised MHCPP & FET & $1.78 \times 10^{-15}$ & $\begin{array}{l}\text { ATP, BSA, Cal, } \\
\text { PDGF-AA }\end{array}$ & [209] \\
\hline Apt based EGFET sensor RCA & EGFET & $8.8 \times 10^{-12}$ & Not shown & [222] \\
\hline $\begin{array}{l}\text { Apt based dual signal amplification } \\
\text { strategy using hydroxyapatite NPs }\end{array}$ & SWV & $\begin{array}{l}1.67 \times 10^{-15} \\
\left(50 \mathrm{fg} \mathrm{mL}^{-1}\right)\end{array}$ & AFP, CEA, IgG, HER2 & [223] \\
\hline Sandwich Ab-Apt labelled ALP & SWV & $\begin{array}{l}1.67 \times 10^{-15} \\
\left(50 \mathrm{fg} \mathrm{mL}^{-1}\right)\end{array}$ & $\begin{array}{l}\text { AFP, CEA, IgG, p53, } \\
\text { HER2 }\end{array}$ & [224] \\
\hline EXPAR & DPV & $52 \times 10^{-15}$ & PDGF-AA, PDGF-AB & [225] \\
\hline $\begin{array}{c}\text { Carbon-based nanocomposites with } \\
\text { Apt-Ag-NCs }\end{array}$ & EIS & $\begin{array}{c}26.5 \times 10^{-15} \\
\left(0.82 \mathrm{pg} \mathrm{mL}^{-1}\right)\end{array}$ & BSA, Thr, Lyz, IgG & [210] \\
\hline Sandwich sensing system on 3D-IHC & Amp & $\begin{array}{c}1.2 \times 10^{-15} \\
\left(0.03 \mathrm{pg} \mathrm{mL}^{-1}\right)\end{array}$ & AA, UA, Gly, Glu & [226] \\
\hline $\begin{array}{l}\text { Aptasensor based on new structure of } \\
\text { GNPs containing } \alpha-C D\end{array}$ & SWV & $0.52 \times 10^{-9}$ & BSA, PSA, HSA, p53 & [227] \\
\hline $\begin{array}{l}\text { Se-doped MWCNTs-Gr, } \\
\text { Hem/G-quadruplex and Y shaped } \\
\text { DNA-aided target-triggered }\end{array}$ & DPV & $27 \times 10^{-15}$ & Thr, IgG, PSA & [213] \\
\hline Apt-Functionalised 3D CNWs & FET & $1.78 \times 10^{-15}$ & Cal, ATP, BSA & [214] \\
\hline \multicolumn{5}{|c|}{ 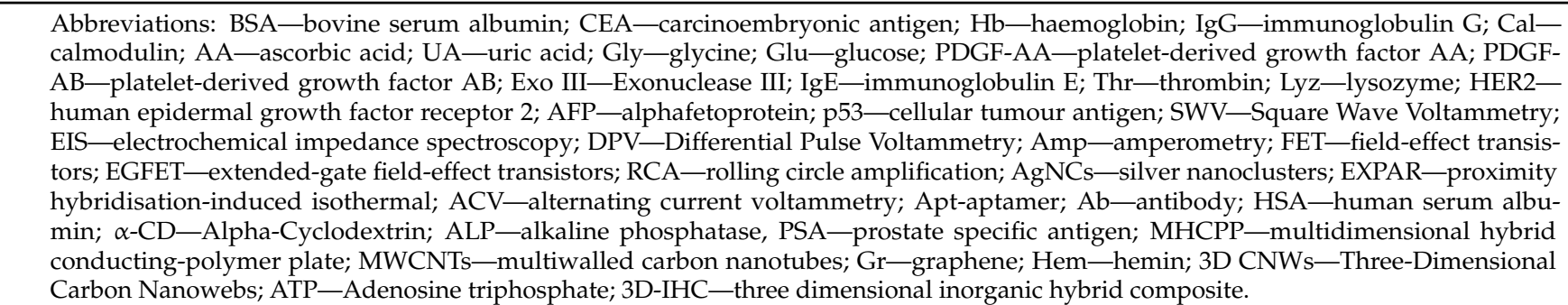 } \\
\hline
\end{tabular}

\subsection{0. $\alpha$-Fetoprotein $(A F P)$}

Alpha-fetoprotein (AFP) is a multifunctional glycoprotein of ca. $70 \mathrm{kDa}$ with a dual regulatory role in cancer and fetal activity [228]. The serum content of AFP can be related to liver carcinomas, and APF is considered as an important diagnostic biomarker of hepatocellular carcinoma (HCC)-one of the most malignant tumours, representing $4.7 \%$ of all cancers. It is also the sixth most common cancer in the world and the third leading cause of cancer deaths in both sexes worldwide [1]. In serum of a healthy human, the AFP concentration does not exceed $25 \mathrm{ng} \mathrm{mL}^{-1}$, but it increases to $500 \mathrm{ng} \mathrm{mL}^{-1}$ in nearly $75 \%$ of HCC patients [229]. A concentration of $20 \mathrm{ng} \mathrm{mL}^{-1}$ is considered as a pathological threshold for AFP in clinical samples [230].

Numerous examples of immunosensors for AFP have been reported [231]. Though the electrochemical AFP aptasensor field is less populated, we selected some interesting results reported during last five years (Table 5). Considering the $20 \mathrm{ng} \mathrm{mL}^{-1}$ pathological threshold for AFP detection, all reported aptasensors' LODs fully meet the clinical requirements, though in many cases samples apparently should be excessively diluted prior analysis.

Among those, graphene-based aptasensors have gained particular attention thanks to such properties of graphene as its large specific surface area, high carrier mobility and electrical conductivity, flexibility, and optical transparency. A simple label-free voltammetric aptasensor based on thionine/rGO/AuNPs-modified SPCE allowed LOD of $0.05 \mu \mathrm{g} \mathrm{mL}^{-1}$ AFP and the response linearity range from 0.1 to $100.0 \mu \mathrm{g} \mathrm{mL}^{-1}$ AFP [232]. A thiolated 
aptamer was immobilised on AuNPs, and the change of thionine redox activity upon AFP binding was DPV-registered. AFP analysis could be performed in human serum and such proteins as BSA, HSA, IgG, and IgE did not interfere [232]. In another simple design, $\mathrm{NH}_{2}$-aptamer was attached to $\mathrm{COOH}-\mathrm{GO}$ deposited onto GCE through the EDC/NHS coupling reaction [233]. To prevent non-specific adsorption, the electrode surface was treated with BSA. The $\mathrm{CV}$ responses from ferro/ferricyanide were linearly proportional to the AFP concentration, within the 0.01 to $100 \mathrm{ng} \mathrm{mL}^{-1}$ range, with LOD of $3 \mathrm{pg} \mathrm{mL}^{-1}$. The aptasensor worked satisfactory in human serum, and PSA and carcinoembryonic antigen did not interfere [233].

A more complicated voltammetric aptasensor exploited the Prussian blue nanoparticle (PBNP) - labelled aptamer immobilised on GO nanosheets deposited onto a gold disk electrode. The AFP binding to the aptamer caused dissociation of PBNP, while in the presence of DNase I, the formed AFP-aptamer complex was cleaved to release AFP, which could again react with the PBNP-labelled aptamer, inducing the AFP recycling. A DPV response changed linearly within the 0.01 to $300 \mathrm{ng} \mathrm{mL}^{-1}$ AFP range, with LOD of $6.3 \mathrm{pg} \mathrm{mL}^{-1}$. AFP was detected in human serum, with a negligible interference from neuron-specific enolase, carcinoembryonic antigen, CA125, human chorionic gonadotropin, and PSA [234].

Nanomaterial-electrode modifications are also intensively explored to improve the sensitivity of the ferricyanide-based assays for AFP. Immobilisation of a thiolated aptamer on spindle-shaped gold nanostructures (ssAuNSs) electrodeposited on a gold electrode (with $\mathrm{MCH}$ as a backfilling agent) allowed the AFP detection within the 0.005 to $10 \mathrm{ng} \mathrm{mL}^{-1}$ range and LOD of $0.23 \mathrm{pg} \mathrm{mL}^{-1}$ [235]. IgG, carcinoembryonic antigen, BSA, and HSA did not interfere with analysis of AFP, and the AFP aptasensor was validated in real samples supported by ELISA tests as a reference [235]. Another nanomaterial strategy suggested immobilisation of a DNA aptamer on 3D-nitrogen-doped nanoporous carbon nanomaterials ( $\mathrm{N}-\mathrm{nCN})$, obtained by pyrolysis (calcination) of green bristle grass and deposited on the gold electrode [236]. The AFP binding produced the DPV signal within the $0.1 \mathrm{pg} \mathrm{mL}^{-1}$ to $100 \mathrm{ng} \mathrm{mL}^{-1}$ range, with LOD of $60.8 \mathrm{fg} \mathrm{mL}^{-1}$. The aptasensor detected AFP in cancer patients' serum samples with low interference from BSA, IgG, and other cancer-related proteins [236].

Alternative electrode modification strategies include emerging materials and less conventional matrices. A DNA aptamer was immobilised on a guanosine-pyridine-4-boronic acid$\mathrm{KCl}$ hydrogel deposited on gold, and the AFP binding detected by EIS with $\left[\mathrm{Fe}(\mathrm{CN})_{6}\right]^{3-/ 4-}$ allowed the 0.001 to $0.5 \mathrm{ng} \mathrm{mL}^{-1} \mathrm{AFP}$ detection and LOD of $0.51 \mathrm{pg} \mathrm{mL}^{-1}$ [237]. The gold electrode functionalised with the metal organic framework - $\mathrm{Cu}$ ions guided MIL-96 octadecahedron crystals - used for the aptamer immobilisation exhibited LOD of $0.12 \mathrm{pg} \mathrm{mL}^{-1}$ AFP and a linear response within the 1 to $500 \mathrm{pg} \mathrm{mL}^{-1}$ range [238].

Redox labelling of the aptamer is another simple yet efficient signal acquisition strategy. An electronic DNA-hairpin beacon, one of the simplest nanoswitching architectures [239] was designed for $8.76 \mathrm{pg} \mathrm{mL}^{-1}$ detection of AFP; a thiolated and MB-labelled aptamer being immobilised on a gold electrode [240]. A more complicated design of the bi-directionally amplified ratiometric aptasensor exploited exonuclease-assisted target recycling and a ferrocene-labelled DNA capture probe (Fc-DNA) [241]. Fc-DNA was hybridised to the thiolated aptamer (DNA1) immobilised on gold, and AFP-aptamer binding resulted in dissociation of Fc-DNA from the hybrid. The process of RecJf exonuclease cleavage allowed further recycling of AFP and more Fc-taged DNA released, accompanied by more DNA1 exposed on the electrode surface for hybridisation with a MB-labelled DNA probe. This aptasensor's LOD reached $0.27 \mathrm{fg} \mathrm{mL}^{-1}$, and AFP was detected in human serum, with no interference from thrombin, carcinoembryonic antigen, IgG, and PSA [241]. Another complex redox labelling strategy was proposed for a sandwich aptasensor design, with AFP captured on the thiolated-aptamer-modified gold electrode and covalently labelled by the Michael addition reaction with the maleimide-functionalised DNA probe [242]. The formed aptamer/AFP/DNA sandwich architecture was subjected to the hybridisation chain reaction induced with the DNA probe and kinetically trapped two MB-labelled 
hairpin DNA. MB voltammetric signals from those changed linearly for $0.1 \mathrm{pg} \mathrm{mL}^{-1}$ to $100 \mathrm{ng} \mathrm{mL}^{-1} \mathrm{AFP}$, and LOD was $0.041 \mathrm{pg} \mathrm{mL}^{-1}$ [242].

To prevent biofouling of the aptamer surface, a thiolated aptamer was also co-immobilised with a zwitterionic peptide as an antifouling agent, and the AFP binding was voltammetrically monitored with ferricyanide as a redox probe [243]. The aptasensor detected AFP at LOD of $3.1 \mathrm{fg} \mathrm{mL}^{-1}$, and HSA did not interfere with the sensor response.

Table 5. The analytical performance of selected electrochemical aptasensors for AFP.

\begin{tabular}{|c|c|c|c|c|}
\hline Strategy & Technique & $\mathrm{LOD}, \mathrm{g} \mathrm{mL}^{-1}$ & $\begin{array}{l}\text { Interference } \\
\text { Studies }\end{array}$ & Ref. \\
\hline $\mathrm{Apt} / \mathrm{ZiP} / \mathrm{Au}$ & \multirow{3}{*}{ DPV } & $3.1 \times 10^{-15}$ & $\begin{array}{l}\text { HSA, } \gamma \text {-globulin, } \\
\text { Hb, ssDNA }\end{array}$ & [243] \\
\hline Hairpin DNA-MB/Au & & $8.76 \times 10^{-12}$ & GP73, CEA & [240] \\
\hline Apt/Thi/rGO/AuNPs/SPCE & & $5 \times 10^{-8}$ & BSA, HSA, IgG, IgE & [232] \\
\hline Apt/GO/GCE & $\mathrm{CV}$ & $3 \times 10^{-12}$ & PSA, CEA & [233] \\
\hline Apt-PB NPs/GO/Au & \multirow{3}{*}{ DPV } & $6.3 \times 10^{-12}$ & $\begin{array}{c}\text { NSE, CEA, MUC16, } \\
\text { hCG, PSA }\end{array}$ & [234] \\
\hline Apt/sAuNPs/Au & & $0.23 \times 10^{-12}$ & IgG, CEA, BSA, HSA & [235] \\
\hline Apt-3D NMCNMs/Au & & $60.8 \times 10^{-15}$ & $\begin{array}{l}\text { BSA, PSA, CEA, IgG, } \\
\text { EGFR, MUC1, VEGF }\end{array}$ & [236] \\
\hline Apt/Gs-Pyr BA-KCl HG/Au & \multirow{2}{*}{ EIS } & $0.51 \times 10^{-12}$ & $\begin{array}{c}\text { Lyz, IgG, } \\
\text { HSA, BSA, CEA }\end{array}$ & [237] \\
\hline Apt/Cu MIL-96 OH/Au & & $0.12 \times 10^{-12}$ & $\begin{array}{c}\text { CEA, IgG, Lyz, BSA, } \\
\text { HSA }\end{array}$ & [238] \\
\hline $\begin{array}{c}\text { HCR-two DNA } \\
\text { hairpins-MB/DNA } \\
\text { probe/AFP/Apt/Au }\end{array}$ & DPV & $0.041 \times 10^{-12}$ & $\mathrm{BSA}, \operatorname{IgG}, \operatorname{IgE}$ & [242] \\
\hline $\begin{array}{l}\text { MB-DNA-AuNPs/AFP/Fc- } \\
\text { capture } \\
\text { probe/MCH/DNA1/Au }\end{array}$ & $\mathrm{ACV}$ & $0.27 \times 10^{-15}$ & Thr, CEA, IgG, PSA & [241] \\
\hline
\end{tabular}

Abbreviations: Au—gold electrode; Apt—aptamer; ZiP—zwitterionic peptide; DPV—differential pulse voltammetry; Hb-haemoglobin, ssDNA—single stranded DNA; CV—cyclic voltammetry; MB—-methylene blue; AFP—alphafetoprotein; Thi—thionine; NSE-neuronspecific enolase; 3D NMCNMs—-three-dimensional nitrogen-doped mesoporous carbon nanomaterials; GP73-golgi protein 73; CEAcarcinoembryonic antigen; BSA—bovin serum albumin; HSA—human serum albumin; IgE—immunoglobulin E; IgG—immunoglobulin G; GO—graphene oxide; rGO—reduced graphene oxide; AuNPs—gold nanoparticles; hCG—human chorionic gonadotropin; PSA-prostate specific antigen; EGFR - epidermal growth factor receptor; MUC1, MUC16-transmembrane mucins; VEGF-vascular endothelial growth factor; NPs - prussian blue nanoparticles; sAuNS—spindle-shaped gold nanostructure; Lyz-lysozyme; SPCE—screen printed carbon electrode; HCR — hybridisation chain reaction; GCE—glassy carbon electrode; EIS—electrochemical impedance spectroscopy; Fc—ferrocene; $\mathrm{MCH}$-6-mercaptohexan-1-ol; ACV—alternating current voltammetry; Thr-thrombin; Gs-Pyr BA-KCl HG—guanosine-pyridine-4-boronic acid-KCl hydrogel; $\mathrm{Cu}$ MIL-96 OH—Cu ion guided MIL-96 octadecahedron.

\subsection{Carcinoembryonic Antigen (CEA)}

Carcinoembryonic antigen (CEA) is a heavily glycosylated $180 \mathrm{kDa}$ cell-surface glycoprotein that is involved in cell adhesion and expressed during human foetal development. This oncofoetal protein is abnormally expressed in many human cancers, such as breast, lung, gastric, ovarian, thyroid, and pancreatic cancer, but is most commonly associated with colorectal cancer. It is abundantly expressed in approximately $95 \%$ cases of colorectal cancer $[244,245]$, which is the third most prevalent cancer and the second cause of cancer fatality worldwide [1]. The detection of CEA cancer biomarker thus became essential for differential diagnosis, condition monitoring, and therapeutic assessment of colon cancers with a cut-off of $5 \mathrm{ng} \mathrm{mL} \mathrm{m}^{-1}$ [246].

Over the last five years, an impressive number of electrochemical aptasensors for the CEA detection have been developed and we summarise the most recent examples in this section and Table 6. 
A variety of nanomaterials and nanocomposites was used both for the aptamer immobilisation and labelling: graphene-based nanomaterials [247-256], nanocomposite $\mathrm{Zr}$ metal-organic frameworks with Ag nanoclusters [257], and avidin-gated mesoporous silica nanoparticles [258].

A multi-signal-amplified voltammetric aptasensor exploiting the lead-based metal organic framework (Pb-MOF) signal marker enabled a $0.333 \mathrm{pg} \mathrm{mL}^{-1}$ CEA detection in serum, within the $0.001-100 \mathrm{ng} \mathrm{mL}^{-1}$ range [254]. A DNA aptamer-modified gold electrode was combined with the Pb-MOF-labelled dendritic DNA nanostructures formed in the hybridisation chain reaction. The target substitution reaction released internal $\mathrm{Pb}^{2+}$ ions to be detected by SWV. The aptasensor results were comparable with ELISA [254].

Zheng and colleagues proposed a strategy of designing a biosensor for CEA detection based on copper silicate integrated with nitrogen-doped magnetic carbon microtubes (NCMTs@ $\mathrm{Fe}_{3} \mathrm{O}_{4} @ \mathrm{Cu}$ silicate). For this purpose, concanavalin A (ConA) was bound to the previously synthesised NCMTs@ $\mathrm{Fe}_{3} \mathrm{O}_{4} @ \mathrm{Cu}$ silicate composite by chelating with copper ions. ConA acted as an affinity probe for the selective capturing of CEA. Next, gold nanoclusters (AuNCs) labelled with the DNA aptamer interacted with CEA, creating a sandwich. The electrochemical response of this aptasensor was generated by the electrochemical oxidation of $\mathrm{AuNCs}$ to $\mathrm{AuCl}_{4}{ }^{-}$. It detected CEA within a linear range from 0.03 to $6.00 \mathrm{ng} \mathrm{mL}^{-1}$ and LOD of $5.38 \mathrm{pg} \mathrm{mL}^{-1}$. The analytical performance of the assay in human serum gave satisfactory results [259].

Co-polymerisation of polydopamine and poly(sulfobetaine methacrylate) on GCE provided a matrix for a thiolated DNA aptamer immobilisation via the Michael addition reaction. An electrochemical sensing performance of the aptasensor was investigated $\left[\mathrm{Fe}(\mathrm{CN})_{6}\right]^{3+/ 4+}$. It displayed a linear range of 0.01 to $10 \mathrm{pg} \mathrm{mL}^{-1}$ and LOD of $3.3 \mathrm{fg} \mathrm{mL}^{-1}$ and operated in human serum samples [260].

The $\mathrm{Cu}_{3}\left(\mathrm{PO}_{4}\right)_{2}$ nanoflowers/GO nanocomposites $\left(\mathrm{Cu}_{3}\left(\mathrm{PO}_{4}\right)_{2} \mathrm{NF} @ \mathrm{GO}\right)$ represented another platform for the biotinylated DNA aptamer immobilisation, via the biotinstreptavidin linkage [255]. The reaction of molybdophosphate precipitation from $\mathrm{Cu}_{3}\left(\mathrm{PO}_{4}\right)_{2}$ NF@GO and molybdate $\left(\mathrm{MoO}_{4}{ }^{2-}\right)$ electrochemistry were used as an indicator. CEA binding to the aptamer hindered the molybdophosphate formation and decreased the electrochemical signal from molybdite, changing linearly with the CEA logarithmic concentration in the range from $10 \mathrm{fg} \mathrm{mL}^{-1}$ to $500 \mathrm{ng} \mathrm{mL}^{-1}$ (LOD of $2.4 \mathrm{fg} \mathrm{mL}^{-1}$ ) [255].

A conductive strip paper-based aptasensor detected CEA in the 0.77 to $14 \mathrm{ng} \mathrm{mL}^{-1}$ range, with LOD of $0.45 \mathrm{ng} \mathrm{mL}^{-1}$ and $1.06 \mathrm{ng} \mathrm{mL}^{-1}$ in buffer and human serum samples [256]. The sensing layer represented graphene and poly (3,4-ethylenedioxythiophene): poly(styrenesulfonate) (PEDOT:PSS) nanocomposite, (3-aminopropyl) triethoxysilane (APTES), succinic anhydride (SA), DNA aptamers, and BSA. APTES provided amine groups on the electrode surface and SA-carboxyl groups for attachment of the aminated aptamer. Ferricyanide was a redox probe for the impedimetric detection of CEA [256].

A toehold-aided DNA recycling voltammetric aptasensor exploited a SH-ssDNA probe hybridised with DNA1 and DNA2 to form a 3'-toehold domain [261]. Partially hybridised SH-ssDNA immobilised on gold ( $\mathrm{MCH}$ used for surface backfilling) reacted with a complex of CEA-aptamer and a free DNA probe. The latter was hybridised with SHssDNA and triggered toehold-aided DNA recycling. Finally, MB-labelled DNA3 hybridised to SH-ssDNA, and the MB signal was proportional to the logarithmic concentration of the assayed CEA (the 0.1 to $50 \mathrm{ng} \mathrm{mL}^{-1}$ linear range, LOD of $20 \mathrm{pg} \mathrm{mL}^{-1}$ ). This aptasensor operated in spiked serum, urine, and saliva [261]. 
Table 6. The analytical performance of selected electrochemical for CEA.

\begin{tabular}{|c|c|c|c|c|}
\hline Strategy & Technique & LOD, $\mathrm{g} \mathrm{mL}^{-1}$ & $\begin{array}{l}\text { Interference } \\
\text { Studies }\end{array}$ & Ref. \\
\hline $\begin{array}{c}\text { Glu ox-Fc nanoporous } \\
\text { AuNSs/CEA/MCH/Apt/Au }\end{array}$ & \multirow{2}{*}{ DPV } & $0.45 \times 10^{-12}$ & $\begin{array}{l}\text { HSA, human IgG, } \\
\text { mouse IgG }\end{array}$ & [262] \\
\hline MCH/Apt/AuNPs-Hem/GCE & & $40 \times 10^{-15}$ & HSA, Thr, Lyz, Ins & [247] \\
\hline Apt-C-PPy MNTs/IDMA & FET & $1 \times 10^{-15}$ & Thr, BSA, DP, AA, UA & [263] \\
\hline AuNPs-Apt 2-CEA-Apt1/Au & Amp & $\begin{array}{l}0.899 \times 10^{-12} \\
(5 \mathrm{fM})\end{array}$ & PSA, BSA & [264] \\
\hline H Apt +AuNRs Gr-strp NM/GCE & DPV & $1.5 \times 10^{-12}$ & Myo, Fer, IgG & [248] \\
\hline $\begin{array}{c}\mathrm{H} 1+\mathrm{H} 2+\mathrm{MnTMPyP} / \mathrm{Pt}-\mathrm{Pd}- \\
\text { Apt2/CEA/BSA/Apt1/AuNPs/GCE }\end{array}$ & EIS & $0.03 \times 10^{-12}$ & $\begin{array}{l}\text { Thr, rabbit IgG, AFP, } \\
\text { PSA }\end{array}$ & [265] \\
\hline $\mathrm{UiO}-66-\mathrm{AgNCs}-\mathrm{Apt} / \mathrm{Au}$ & $\begin{array}{c}\text { EIS } \\
\text { DPV }\end{array}$ & $\begin{array}{l}8.88 \times 10^{-12} \\
4.93 \times 10^{-12}\end{array}$ & AA, MUC1, Thr, IgG, & [257] \\
\hline $\begin{array}{c}\text { BSA/Apt/AuNPs/Gr-MoSe } \\
\text { hybrid/GCE }\end{array}$ & DPV & $0.03 \times 10^{-12}$ & $\begin{array}{l}\text { HSA, IgE, AFP, Thr, } \\
\text { LDL }\end{array}$ & [249] \\
\hline $\begin{array}{c}\mathrm{MoO}_{4}{ }^{2-} / \mathrm{AuNRs}-\mathrm{Apt} / \mathrm{Ab}- \\
\mathrm{CEA} / \mathrm{GO} / \mathrm{GCE}\end{array}$ & SWV & $0.05 \times 10^{-12}$ & AFP, MUC16, IgG & [250] \\
\hline $\begin{array}{c}\text { CuMOFs-PtNPs-Apt2-hemin- } \\
\text { GOx/CEA/BSA/Apt1/AuNPs/GCE }\end{array}$ & EIS & $0.023 \times 10^{-12}$ & Thr, IgG, AFP, PSA & [251] \\
\hline $\begin{array}{l}\text { Auxiliary DNA/Pb } \\
\text { chain-MB / DNAzyme: } \\
\text { Hairpin-CEA/GrQD-IL-Naf/GCE }\end{array}$ & \multirow{3}{*}{ DPV } & $0.34 \times 10^{-15}$ & BSA, PSA, MUC1 & [252] \\
\hline $\begin{array}{l}\text { Compl. strands: DNA1 and } \\
\text { DNA2/Hairpins: Apt1 + Apt2/SPAuE }\end{array}$ & & $0.9 \times 10^{-12}$ & $\begin{array}{l}\text { IgE, Thr, HSA, Gly, } \\
\text { Myo, PSA }\end{array}$ & [266] \\
\hline $\mathrm{HRP} / \mathrm{ConA} / \mathrm{CEA} / \mathrm{DNA} \mathrm{Apt}+\mathrm{MCH} / \mathrm{Au}$ & & $3.4 \times 10^{-9}$ & $\begin{array}{l}\text { BSA, HSA, r-globulin, } \\
\text { AFP, CRP }\end{array}$ & [267] \\
\hline Apt/NiCoPBA/Au & EIS & $0.74 \times 10^{-15}$ & $\begin{array}{l}\text { BSA, HER2, IgG, PSA, } \\
\text { VEGF, MUC1 }\end{array}$ & [268] \\
\hline $\begin{array}{c}\text { MSiNPs-MB-Av/IBNc } \\
\text { /CEA/BSA/Apt/AuNPs/SPCE }\end{array}$ & \multirow{3}{*}{ DPV } & $\begin{array}{c}280 \times 10^{-15} \text { (buffer) } \\
510 \times 10^{-15}(\mathrm{HS})\end{array}$ & Not shown & [258] \\
\hline DMP DTPs HCR/Au & & $18.2 \times 10^{-15}$ & $\mathrm{Hb}$, PSA, Thr & [269] \\
\hline EA/Apt/Hem-GO-MWCNs/GCE & & $0.82 \times 10^{-15}$ & $\begin{array}{l}\text { Ins, Ua, Glu, Arg, Gly, } \\
\text { HSA }\end{array}$ & [253] \\
\hline $\begin{array}{c}\mathrm{Au}-\mathrm{SiO}_{2} \mathrm{Janus} \\
\text { nanoparticles-Apt/Av-Fe } \mathrm{O}_{4} @ \mathrm{SiO}_{2} \\
\text { NanoCaptors } / \mathrm{SPCE}\end{array}$ & Amp & $210 \times 10^{-12}$ & Thr, IgG, HSA & [270] \\
\hline $\begin{array}{c}\text { HRP-Cu } \mathrm{Cu}_{3}\left(\mathrm{PO}_{4}\right)_{2} \text { hybrid } \\
\text { nanoflowers-AuNPs-Apt2- } \\
\text { BSA/EA/BSA/Apt1/Hemin-rGO- } \\
\text { AuNPs/GCE }\end{array}$ & DPV & $29 \times 10^{-15}$ & Thr, Cys, Hb, PSA, & [271] \\
\hline $\begin{array}{l}\text { sDNA-Pb-MOF/H1 and } \\
\text { H2-HCR/DNA/Apt/Au }\end{array}$ & SWV & $0.33 \times 10^{-12}$ & Myo, BSA, MUC1, PSA & [254] \\
\hline Apt/PDA + PSBMA/GCE & DPV & $3.3 \times 10^{-15}$ & $\begin{array}{l}\text { Lyz, } \gamma \text {-globulin, MB, } \\
\text { IgG, BSA, HSA }\end{array}$ & [260] \\
\hline $\begin{array}{c}\mathrm{MoO}_{4}{ }^{2-} / \mathrm{CEA} / \mathrm{Apt}-\mathrm{Cu}_{3}\left(\mathrm{PO}_{4}\right)_{2} \text { hybrid } \\
\text { nanoflowers + GO composites/GCE }\end{array}$ & SWV & $2.4 \times 10^{-15}$ & PSA, Thr, $\mathrm{Hb}$ & [255] \\
\hline $\begin{array}{l}\text { BSA/Apt/SA/APTES/Gr- } \\
\text { PEDOT:PSS/PSE }\end{array}$ & EIS & $\begin{array}{c}0.45 \times 10^{-9} \text { (buffer) } \\
1.06 \times 10^{-9}(\mathrm{HS})\end{array}$ & BSA, PSA, Ins & [256] \\
\hline
\end{tabular}


Table 6. Cont.

\begin{tabular}{|c|c|c|c|c|}
\hline $\begin{array}{c}\text { DNA3- } \\
\mathrm{MB} / \mathrm{CEA} / \mathrm{Apt} / \mathrm{MCH} / \mathrm{DNA} 2 / \mathrm{DNA} 1 / \mathrm{SH}- \\
\text { ssDNA/Au }\end{array}$ & SWV & & & 61] \\
\hline $\begin{array}{c}\text { AuNCs-Apt/CEA/ConA/NCMTs- } \\
\mathrm{Fe}_{3} \mathrm{O}_{4}-\mathrm{Cu} \\
\text { silicate } / \mathrm{Au}\end{array}$ & DPV & 5.38 & IgG, & [259] \\
\hline \multicolumn{5}{|c|}{ 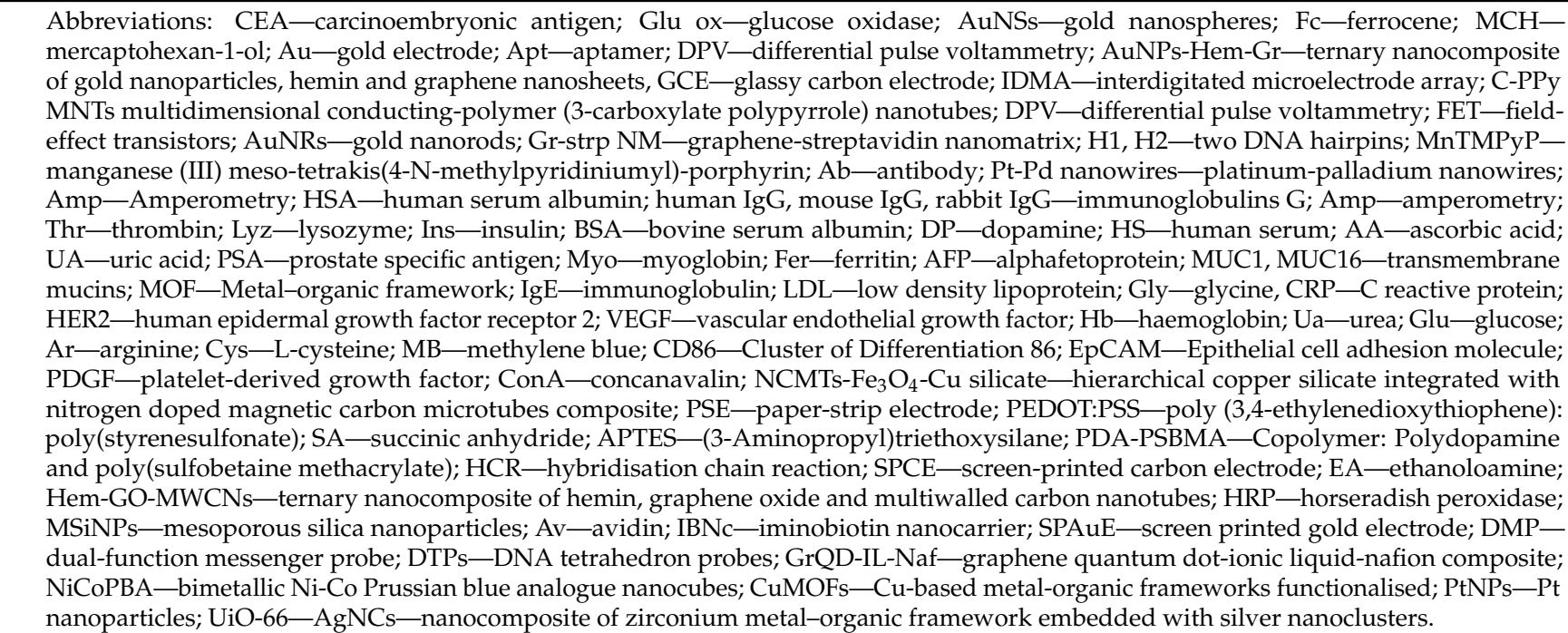 } \\
\hline
\end{tabular}

\section{Multiplex Electrochemical Aptasensor Platforms for Several Cancer Biomarker Detection}

Simultaneous detection of multiple biomarkers allows efficient screening, diagnosis, and monitoring of neoplastic diseases. Despite significant recent advances in the development of aptasensors, most research is still focused on single-analyte detection. However, clinical trials request the accurate and sensitive multianalyte detection, providing a much more detailed information on a range of biomarkers and cancer state.

To address the challenge of saving the time and cost of multiplex analysis, a voltammetric dual sensor for the parallel and continuous detection of MUC1 and CEA was constructed by using a thiolated SH-DNA probe attached to the MCH-blocked gold electrode surface [272]. The MB-labelled MUC1-specific and CEA-specific aptamer sequences were immobilised on the DNA-modified electrodes via their hybridisation with the SH-DNA probe in a way that $\mathrm{MB}$ was a signal-on probe for MUC1 binding and a signal-off probe for the CEA detection. The simultaneous analysis of two proteins showed the linear response to MUC1 within the $10 \mathrm{nM}$ to $100 \mathrm{nM}$ range (LOD of $0.6 \mathrm{nM}$ ) and from $30 \mathrm{ng} \mathrm{mL}^{-1}$ to $300 \mathrm{ng} \mathrm{mL}^{-1} \mathrm{CEA}$ (LOD of $2.75 \mathrm{ng} \mathrm{mL}^{-1}$ ). Inverse trends in the current signal changes were observed with the increasing concentrations of MUC1 and CEA, generating an increment and a decrement in the current response, respectively. Tumour necrosis factor- $\alpha$ (TNF- $\alpha$ ) and thrombin produced significantly lower responses. The aptasensor continuously monitored CEA (after the MUC1 binding) at LOD lowered then to $0.5 \mathrm{ng} \mathrm{mL}^{-1}$ [272]. Moreover, the aptasensor can be regenerated by rehybridisation of DNA2 or DNA3-MB after the parallel detection targets, or by introducing MUC1 and CEA and then rehybridising the MUC1 and CEA aptamers with linker DNA1 on the gold electrode. Therefore, it can be elucidated that this present strategy provides different protocols (parallel and continuous detection) to meet the requirements of analytical applications [272].

Another strategy is based on using multiple redox labels for simultaneous analysis of several proteins, such as an aptasensor exploiting two different integrated signalling probes (ISP) - two aptamers labelled with MB and Fc redox tags (sP1 and sP2) [273]. ISPs were immobilised onto the AuNP-modified GCE (blocked with MCH), and CEA and MUC1 binding resulted in a gradual decrease of both currents from MB and Fc detected 
by SWV. The linear range for the CEA detection was from $1 \mathrm{ng} \mathrm{mL}^{-1}$ to $1 \mu \mathrm{g} \mathrm{mL} \mathrm{L}^{-1}$ and for MUC1-from $5 \mathrm{nM}$ to $1 \mu \mathrm{M}$. LODs for individual analysis of CEA and MUC1 were $0.517 \mathrm{ng} \mathrm{mL}^{-1}$ and $1.06 \mathrm{nM}$, while for parallel analysis they were $0.5274 \mathrm{ng} \mathrm{mL}^{-1}$ and $1.82 \mathrm{nM}$, respectively. HSA and HIgG did not interfere with CEA and MUC1 analysis. Comparing with the conventional independent signal probes for the simultaneous multianalyte detection, the proposed ISP was more reproducible and accurate. This can be due to the fact that ISP in one DNA structure can ensure the completely identical modification condition and an equal stoichiometric ratio between sP1 and sP2, and, furthermore, the cross interference between $\mathrm{sP} 1$ and $\mathrm{sP} 2$ can be successfully prevented by regulating the complementary position of sP1 and sP2 [273].

Shell-encoded AuNPs: $\mathrm{Au} @ \mathrm{Cu}_{2} \mathrm{O}$ core-shell NPs and Au@Ag core-shell NPs were suggested as dual-analysis labels with redox potentials at $-0.08 \mathrm{~V}$ and $0.26 \mathrm{~V}$, correspondingly [274]. Two aminated DNA probes were immobilised via sulfamine bonds on the surface of GCE-containing sulfonic groups introduced by reductive electrolysis of 4-aminobenzenesulfonic acid, and AuNPs-Ag- and $\mathrm{AuNPs}_{-} \mathrm{Cu}_{2} \mathrm{O}$-conjugated AFP and CEA aptamers were hybridised to both. AFP- and CEA-aptamer complex formations removed the AuNPs-labelled aptamers from the electrode surface, which resulted in the decreasing DPV signals from the shell-encoded AuNPs. The non-interfering and amplified DPV responses enable shell-encoded Au NPs to be an alternative electrochemical signal amplifier for dual screening of CEA and AFP. The duo-sensor showed linearity of responses for both biomarkers in the ranges from $1 \mathrm{pg} \mathrm{mL}^{-1}$ to $10 \mathrm{ng} \mathrm{mL}^{-1}$ AFP and from $5 \mathrm{pg} \mathrm{mL}^{-1}$ to $10 \mathrm{ng} \mathrm{mL} \mathrm{m}^{-1} \mathrm{CEA}$, with LODs of $1.8 \mathrm{pg} \mathrm{mL}^{-1} \mathrm{CEA}$ and $0.3 \mathrm{pg} \mathrm{mL}^{-1}$ AFP. This aptasensor operated in blood samples and cellular extracts, with no interference from PSA, thrombin, IgG, L-cysteine, glutathione, arginine, histidine, valine, tryptophan and lysine. In comparison to the parallel single-analyte assays, shell-encoded Au NPs engineered electrochemical aptasensors offer multiplexing capability and show significant prospects in biomedical research and early diagnosis of diseases [274].

Simultaneous multiplexed detection of CEA and neuron specific enolase (NSE) was performed in a paper-based device produced by wax- and screen-printing, which enabled both the filtration and automatic injection of samples [275]. The device consisted of two integrated working carbon electrodes, which could simultaneously detect CEA and NSE in one sample by using two different redox modifications of the electrode. Each of the electrodes was modified either with amino-functionalised graphene-thionine-AuNPs or Prussian bluePEDOT-AuNPs nanocomposites, to which either a thiolated CEA aptamer or a thiolated NSE aptamers were attached through the Au-S chemistry. CEA and NSE binding by the aptamers resulted in the linear drop of the DPV signals, at $-0.25 \mathrm{~V}$ for thionine and at $-0.02 \mathrm{~V}$ for Prussian blue, within the 0.01 to $500 \mathrm{ng} \mathrm{mL}^{-1}$ CEA and $0.05-500 \mathrm{ng} \mathrm{mL}^{-1}$ NSE concentration ranges. LODs of $2 \mathrm{pg} \mathrm{mL}^{-1} \mathrm{CEA}$ and $10 \mathrm{pg} \mathrm{mL}^{-1} \mathrm{NSE}$ were orders of magnitude lower than the cut-off serum values for lung cancer: $5 \mathrm{ng} \mathrm{mL}^{-1} \mathrm{CEA}$ and $15 \mathrm{ng} \mathrm{mL} \mathrm{m}^{-1}$ NSE. A label-free electrochemical method was adopted, enabling a rapid simple point-of-care testing. The aptasensor device was used for clinical serum samples analysis, and BSA, uric and ascorbic acids, and Cyfra21-1 did not interfere [275].

Hyperbranched DNA-LaMnO 3 perovskite (DNA-LMO) nanobiocomposites loaded with three different metal ions were used as redox probes for simultaneous discrimination of three different biomarkers of cancer, AFP, CEA, and PSA (Figure 8, left panel) [276]. Three aptamers were attached to a gold stirring rod and hybridised to DNA-(LMO-M) encoded probes. The encoded probes were prepared stepwise: (1) Three DNA strands complementary to the CEA, AFP, and PSA aptamers were extended by the TdT enzyme to form a long adenine (A)-rich ssDNA; (2) $\mathrm{Pb}^{2+}, \mathrm{Cd}^{2+}$, and $\mathrm{Cu}^{2+}$ ions were loaded onto the LMO nanoparticles then labelled with thymine (T)-rich ssDNA; (3) A-rich ssDNA hybridised with multiple DNA labelled LMO-M to get a set of encoded signal labels corresponding to each biomarker assay DNA-(LMO-M $)_{n}$. After protein binding, the corresponding encoded labels were substituted by AFP, CEA, and PSA biomarkers, and SWV analysis of the supernatant detected the specific metal ion signals from each label 
encoding the particular protein in one run. The current response linearly increased with the protein concentrations in the range of 0.0001 to $100 \mathrm{ng} \mathrm{mL}^{-1}$, and LODs were $0.34 \mathrm{pg} \mathrm{mL}^{-1}$ AFP, $0.36 \mathrm{pg} \mathrm{mL}^{-1}$ CEA and $0.28 \mathrm{ng} \mathrm{mL}^{-1}$ PSA. Since the stirring rod can enrich many encoded probes containing many metal ions, multiplex signal amplification can be realised. Due to the enrichment and easy separation of the stirring rod, the signal-to-noise ratio was also obviously improved and thus to results in good sensitivity and accuracy. The results of electroanalysis of patients' sera samples were comparable with those of ELISA [276].
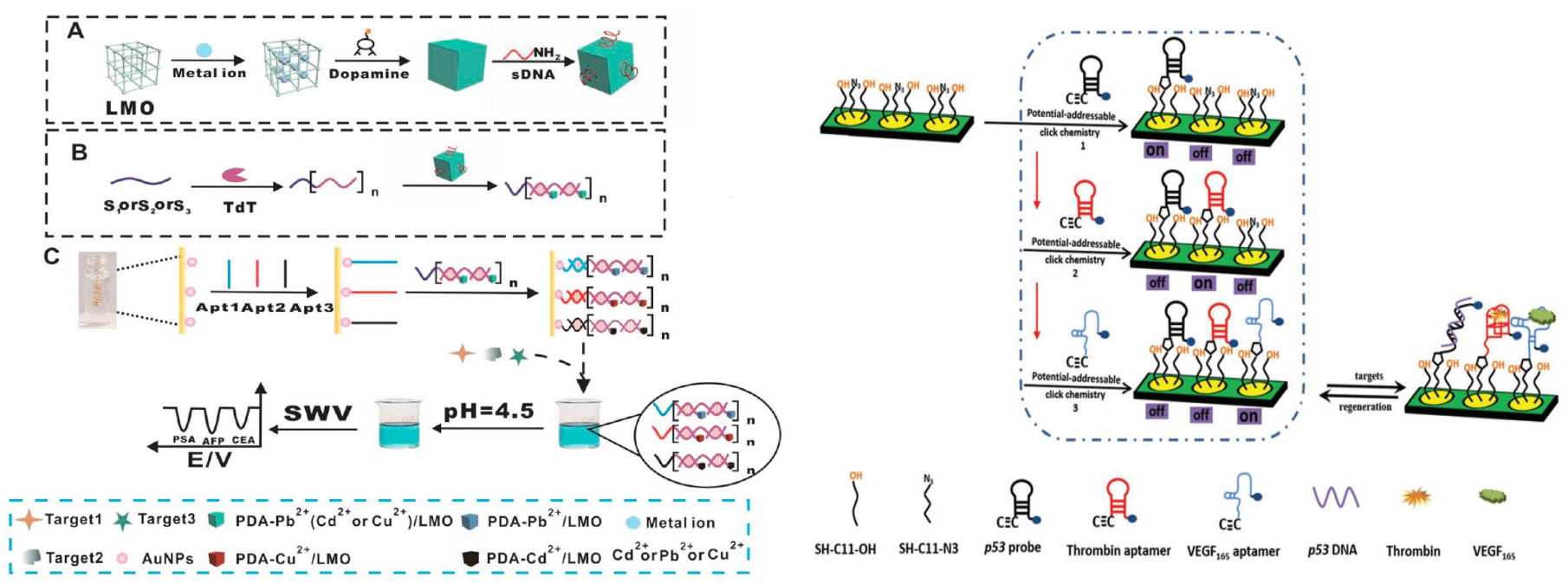

Figure 8. Aptasensors for multiplex detection of biomarkers (left panel) based on hyperbranched DNA-LaMnO $\mathrm{D}_{3}$ perovskite (DNA-LMO) nanobiocomposites probes loaded with metal ions [276], Copyright (2021) Elsevier, reprinted with permission, and (right panel) based on a three-channel carbon SPCE selectively modified with DNA probes specific for three different analytes, reproduced from ref. [277] with permission from The Royal Society of Chemistry.

Further, the possibility of a three-analyte detection-of p53 DNA, thrombin, and VEGF165-was shown with a three-channel carbon SPCE selectively modified with DNA probes specific for those analytes (Figure 8, right panel) [277]. SPCE were gold-plated and modified with a mixed SAM of azidoundecanthiol and mercaptoundecanol. Surface functionalisation with three different MB-labelled probes (p53 DNA- and protein-specific sequences) was performed by "click" chemistry assisted by electrocatalytically generated $\mathrm{Cu}(\mathrm{I})$. The reaction was carried out by sequential exposure of each azide-modified electrode to "click" solutions with a potential bias $(-0.4 \mathrm{~V})$ applied only to the selected electrode. The ACV responses of the electronic beacons formed on each of three working electrodes to their analytes linearly changed with the analyte concentrations, for $1.0 \mathrm{nM}$ to $128 \mathrm{nM}$ p53 DNA, $0.8 \mathrm{nM}$ to $40 \mathrm{nM}$ thrombin, and $0.1 \mathrm{nM}$ to $5.0 \mathrm{nM}$ VEGF165, respectively. LODs were $0.35 \mathrm{nM}$ p53 DNA, $0.22 \mathrm{nM}$ thrombin, and $0.014 \mathrm{nM}$ VEGF165, and the aptasensor operated in fetal bovine serum [277].

\section{Conclusions and Future Directions}

It is clear that recent advances in the construction of electrochemical aptasensors for protein cancer biomarkers allow considering them as robust tools for efficient and reliable analysis of these proteins in physiological fluids, operating often at concentration levels well below the clinically required limits. Compared both to the optical and electrochemical immunoassay approaches, using aptamers as biorecognition elements makes the aptasensor development much more versatile and more easily compatible with nanomaterials and DNA nanotechnologies, both at the level of chemical modifications of the aptamer sequences and their enzymatic treatments [16]. Current achievements in nanoscience and colloidal particles production, such as production of NPs of the controllable size and properties, allow further optimisation of analytical systems and obtaining detectable signals for trace amounts of proteins [278,279], with this improving the aptasensor performance to the 
required levels of sensitivity. Further, the possibility of easy miniaturisation of the electrochemical aptasensor devices, short analysis time, and relatively low cost (compared to the antibody-based assays) make the electrochemical aptamer-based assays most promising for clinical analytical applications.

However, despite numerous scientific reports on excellently in-lab performing electrochemical aptasensors overviewed here and their apparent analytical and technological advantages, the number of practical applications of aptamers in clinical trials, such as for validation of liquid biopsies for diagnosis of cancers or for routine clinical quantification of already established serum biomarkers of cancer, is scarce. That occurs both due to the current prevalence of the optical ELISA-based approaches impeding the wide acceptance of electrochemical biosensing schemes in clinical practice and due to often complicated or commercially un-attractive solutions for the aptamer-electrode modifications and assay protocols. Insufficient long-term stability of bioelectronics chips, such as those based on thiolated aptamer immobilisations on gold electrodes, which are complicated and have low compatibility with automatic production electrode modifications with multiple nanomaterials and cumbersome assay protocols make upscaling of most of the suggested technological solutions unfeasible, and they do not yet approach the level of commercial kits for research and development, not mentioning the clinically validated device level. Currently, the most successful electrochemical platform for analysis of blood-circulating proteins is Abbott's iStat Systems for acute disease monitoring and Roche cobas ${ }^{\circledR} 6000$ ECL analyser for tumour biomarkers, both exploiting the electrochemical ELISA, i.e., the immunoassay approach $[52,280]$. The next step may be the development of a similarly commercially attractive electrochemical aptamer-based platform for unambiguous analysis of protein signatures of the cancer type and cancer state.

Construction of practical aptasensors for multiplex POCT may be the right step to make electrochemical aptasensors commercially attractive. There were a number of strategies reported for the multiplex analysis (Section 5) based on either simultaneous use of several different aptamers in an array format or of several redox-active probes encoding each aptamer/protein binding, and their further adaptation to multichannel, multianalyte [281], electrode array [282], and label-free detection schemes [283] may further assist the market activation of electrochemical aptasensors for cancer diagnosis. Therewith, the limitations to overcome also include the on-chip reagent storage and decreasing the cost of the miniaturised aptasensors. For the latter, the cost per test is one of the significant value parameters in the POCT sensors development [284].

To sum up, the future development of integrated, portable, and automated electrochemical aptasensor devices for clinical diagnostics of cancer seems to be a realistic goal, and there are a critical number of excellent approaches reported in the scientific literature that may enable that. However, that would not happen without ultimate moving of the electrochemical aptasensors research from the purely electroanalytical to applied clinical applications, entering the translational medicine field.

Funding: This research was funded by the Novo Nordisk Foundation, grant reference number NNF20OC0065428.

Institutional Review Board Statement: Not applicable.

Informed Consent Statement: Not applicable.

Data Availability Statement: It is review and it used already publicaly accessible resources/data.

Conflicts of Interest: The authors declare no conflict of interest.

\section{References}

1. World Health Organization. WHO Report on Cancer. Setting Priorities, Investing Wisely and Providing Care for All; World Health Organization: Geneva, Switzerland, 2020; ISBN 978-92-4-000129-9.

2. Available online: http:/ / www.statcan.gc.ca / cgi-bin /imdb/p2SV.pl?Function=getSurvey\&SDDS=3207\&lang=en\&db=imdb\& $\mathrm{adm}=8 \&$ dis $=2$ (accessed on 3 December 2020). 
3. Available online: https://www.cancerresearchuk.org/ (accessed on 3 December 2020).

4. Raab, S.S.; Grzybicki, D.M. Quality in cancer diagnosis. Cancer J. Clin. 2010, 60, 139-165. [CrossRef] [PubMed]

5. Coleman, M.P.; Forman, D.; Bryant, H.; Butler, J.; Rachet, B.; Maringe, C.; Nur, U.; Tracey, E.; Coory, M.; Hatcher, J.; et al. Cancer survival in Australia, Canada, Denmark, Norway, Sweden, and the UK, 1995-2007 (the International Cancer Benchmarking Partnership): An analysis of population-based cancer registry data. Lancet 2011, 377, 127-138. [CrossRef]

6. Crew, B. Worth the cost? A closer look at the da Vinci robot's impact on prostate cancer surgery. Nature 2020, 580, S5-S7. [CrossRef]

7. Available online: https:/ / ourworldindata.org/cancer-death-rates-are-falling-five-year-survival-rates-are-rising (accessed on 2 December 2020).

8. Soda, N.; Rehm, B.H.A.; Sonar, P.; Nguyen, N.-T.; Shiddiky, M.J.A. Advanced liquid biopsy technologies for circulating biomarker detection. J. Mater. Chem. B 2019, 7, 6670-6704.

9. Hermann, T.; Patel, D.J. Adaptive recognition by nucleic acid aptamers. Science 2000, 287, 820-825. [CrossRef]

10. Colas, P.; Cohen, B.; Jessen, T.; Grishina, I.; McCoy, J.; Brent, R. Genetic selection of peptide aptamers that recognize and inhibit cyclin-dependent kinase 2. Nature 1996, 380, 548-550. [CrossRef]

11. Ellington, A.D.; Szostak, J.W. Selection in vitro of single-stranded DNA molecules that fold into specific ligand-binding structures. Nature 1992, 355, 850-852.

12. Ferapontova, E.E.; Gothelf, K.V. Recent advances in electrochemical aptamer-based sensor. Curr. Org. Chem. 2011, 15, 498-505. [CrossRef]

13. Díaz-Fernández, A.; Lorenzo-Gómez, R.; Miranda-Castro, R.; delos-Santos-Álvarez, N.; Lobo-Castañón, M.J. Electrochemical aptasensors for cancer diagnosis in biological fluids-A review. Anal. Chim. Acta 2020, 1124, 1-19.

14. Hasegawa, H.; Taira, K.-I.; Sode, K.; Ikebukuro, K. Improvement of aptamer affinity by dimerization. Sensors 2008, 8, 1090-1098. [CrossRef]

15. Riccardi, C.; Napolitano, E.; Musumeci, D.; Montesarchio, D. Dimeric and multimeric DNA aptamers for highly effective protein recognition. Molecules 2020, 25, 5227. [CrossRef] [PubMed]

16. Kjems, J.; Ferapontova, E.E.; Gothelf, K.V. Nucleic Acid Nanotechnology; Springer: Berlin/Heidelberg, Germany, $2014 ;$ Volume 29.

17. Kong, H.Y.; Byun, J. Nucleic acid aptamers: New methods for selection, stabilization, and application in biomedical science. Biomol. Ther. 2013, 21, 423-434. [CrossRef] [PubMed]

18. Available online: https:/ /www.rcsb.org/structure/2L5K (accessed on 2 December 2020).

19. Available online: https://www.rcsb.org/structure/2M53 (accessed on 2 December 2020).

20. Available online: https://www.rcsb.org/structure/4HQU (accessed on 2 December 2020).

21. Li, J.; Tan, S.; Chen, X.; Zhang, C.-Y.; Zhang, Y. Peptide aptamers with biological and therapeutic applications. Curr. Med. Chem. 2011, 18, 4215-4222. [CrossRef] [PubMed]

22. Mascini, M.; Palchetti, I.; Tombelli, S. Nucleic acid and peptide aptamers: Fundamentals and bioanalytical aspects. Angew. Chem. Int. Ed. 2012, 51, 1316-1332. [CrossRef] [PubMed]

23. Song, S.; Na, J.; Jang, M.H.; Lee, H.; Lee, H.-S.; Lim, Y.-B.; Choi, H.; Chae, Y. A CMOS VEGF sensor for cancer diagnosis using a peptide aptamer-based functionalized microneedle. IEEE Trans. Biomed. Circuits Syst. 2019, 13, 1288-1299. [CrossRef]

24. Zhang, Y.; Lai, B.S.; Juhas, M. Recent advances in aptamer discovery and applications. Molecules 2019, 24, 941. [CrossRef]

25. Dunn, M.; Jimenez, R.; Chaput, J. Analysis of aptamer discovery and technology. Nat. Rev. Chem. 2017, 1, 0076. [CrossRef]

26. Han, K.; Liang, Z.; Zhou, N. Design Strategies for Aptamer-Based Biosensors. Sensors 2010, 10, 4541-4557. [CrossRef]

27. Wang, H.Q.; Wu, Z.; Tang, L.J.; Yu, R.Q.; Jiang, J.H. Fluorescence protection assay: A novel homogeneous assay platform toward development of aptamer sensors for protein detection. Nucleic Acids Res. 2011, 39, e122. [CrossRef]

28. Cho, E.J.; Lee, J.W.; Ellington, A.D. Applications of aptamers as sensors. Annu. Rev. Anal. Chem. 2009, 2, 241-264. [CrossRef]

29. Zhang, X.; Yadavalli, V.K. Surface immobilization of DNA aptamers for biosensing and protein interaction analysis. Biosens. Bioelectron. 2011, 26, 3142-3147. [CrossRef] [PubMed]

30. Forouzanfar, S.; Alam, F.; Pala, N.; Wang, C. Review-A review of electrochemical aptasensors for label-free cancer diagnosis. J. Electrochem. Soc. 2020, 167, 067511. [CrossRef]

31. Vasilescu, A.; Marty, J.-L. Electrochemical aptasensors for the assessment of food quality and safety. TrAC Trends Anal. Chem. 2016, 79, 60-70. [CrossRef]

32. Labib, M.; Sargent, E.H.; Kelley, S.O. Electrochemical methods for the analysis of clinically relevant biomolecules. Chem. Rev. 2016, 116, 9001-9090. [CrossRef]

33. Scozzari, A. Electrochemical sensing methods: A brief review. In Algal Toxins: Nature, Occurrence, Effect and Detection; Evangelista, V., Ed.; Springer: Berlin/Heidelberg, Germany, 2008.

34. Salek-Maghsoudi, A.; Vakhshiteh, F.; Torabi, R. Recent advances in biosensor technology in assessment of early diabetes biomarkers. Biosens. Bioelectron. 2018, 99, 122-135. [CrossRef]

35. Karunakaran, C.; Bhargava, K.; Benjamin, R. (Eds.) Biosensors and Bioelectronics; Elsevier: Amsterdam, The Netherlands, 2015.

36. Bettazzi, F.; Marraza, G.; Minunii, M. Biosensors and related bioanalytical tools. Compr. Anal. Chem. 2017, 77, 1-33.

37. Caygill, R.L.; Blair, G.E.; Millner, P.A. A review on viral biosensors to detect human pathogens. Anal. Chim. Acta 2010, 681, 8-15. [CrossRef]

38. Ramaley, L.; Krause, M. Theory of square wave voltammetry. Anal. Chem. 1969, 41, 1362-1365. [CrossRef] 
39. Gupta, V.; Jain, R.; Radhapyari, K.; Jadon, N.; Agarwal, S. Voltammetric techniques for the assay of pharmaceuticals-A review. Anal. Biochem. 2011, 408, 179-196. [CrossRef]

40. Laborda, E.; Molina, A.; Martinez-Ortiz, F.; Compton, R. Electrode modification using porous layers. Maximising the analytical response by choosing the most suitable voltammetry: Differential pulse vs. square wave vs. linear sweep voltammetry. Electrochim. Acta 2012, 73, 3-9.

41. Chen, A.; Shah, B. Electrochemical sensing and biosensing based on square wave voltammetry. Anal. Methods 2013, 5, 2158-2173.

42. Yang, L.; Bashir, R. Electrical/electrochemical impedance for rapid detection of foodborne pathogenic bacteria. Biotechnol. Adv. 2008, 26, 135-150. [PubMed]

43. Vu, C.-A.; Chen, W.-Y. Field-effect transistor biosensors for biomedical applications: Recent advances and future prospects. Sensors 2019, 19, 4214.

44. Shui, B.; Tao, D.; Florea, A.; Cheng, J.; Zhao, Q.; Gu, Y.; Li, W.; Jaffrezic-Renault, N.; Mei, Y.; Guo, Z. Biosensors for Alzheimer's disease biomarker detection: A review. Biochimie 2018, 147, 13-24. [PubMed]

45. Radecki, J.; Radecka, H.; Cieśla, J.; Tudek, B. Chemical sensors and biosensors in genetically modified food control. BioTechnologia 2006, 3, 67-78.

46. Kwak, B.S.; Kim, H.O.; Kim, J.H.; Lee, S.; Jung, H.-I. Quantitative analysis of sialic acid on erythrocyte membranes using a photothermal biosensor. Biosens. Bioelectron. 2012, 35, 484-488.

47. Fogel, R.; Limson, J.; Seshia, A.A. Acoustic biosensors. Essays Biochem. 2016, 60, 101-110.

48. Zangar, R.C.; Daly, D.S.; White, A.M. ELISA microarray technology as a high-throughput system for cancer biomarker validation. Expert Rev. Proteom. 2006, 3, 37-44.

49. Arya, S.K.; Estrela, P. Recent advances in enhancement strategies for electrochemical ELISA-based immunoassays for cancer biomarker detection. Sensors 2018, 18, 2010.

50. Celine, I.L.; Duarte, J.A.C.; Rocha-Santos, T.A.P. Detection of ErbB2: Nanotechnological solutions for clinical diagnostics; in a book I send: Immunosensors in Clinical Laboratory Diagnostics. RSC Adv. 2014, 4, 3422.

51. Cooper, M. Optical biosensors in drug discovery. Nat. Rev. Drug Discov. 2002, 1, 515-528. [CrossRef] [PubMed]

52. Kulasingam, V.; Jung, B.P.; Blasutig, I.M.; Baradaran, S.; Chan, M.K.; Aytekin, M.; Colantonio, D.A.; Adeli, K. Pediatric reference intervals for 28 chemistries and immunoassays on the Roche cobas ${ }^{\circledR} 6000$ analyzer-A CALIPER pilot study. Clin. Biochem. 2010, 43, 1045-1050. [CrossRef] [PubMed]

53. Wang, J. Analytical Electrochemistry, 3rd ed.; John Wiley \& Sons, Inc.: Hoboken, NJ, USA, 2006.

54. Rusling, J.F.; Kumar, C.V.; Gutkind, J.S.; Patel, V. Measurement of biomarker proteins for point-of-care early detection and monitoring of cancer. Analyst 2010, 135, 2496. [CrossRef] [PubMed]

55. Baird, G.S. Where are all the aptamers? Am. J. Clin. Pathol. 2010, 134, 529. [CrossRef] [PubMed]

56. Binte Jamal, R.; Shipovskov, S.; Ferapontova, E.E. Electrochemical immuno- and aptamer-based assays for bacteria: Pros and cons over traditional detection schemes. Sensors 2020, 20, 5561. [CrossRef]

57. Alvarez-Martos, I.; Campos, R.; Ferapontova, E.E. Surface state of the dopamine RNA aptamer affects specific recognition and binding of dopamine by the aptamer-modified electrodes. Analyst 2015, 140, 4089-4096. [CrossRef]

58. Bogomolova, A.; Komarova, E.; Reber, K.; Gerasimov, T.; Yavuz, O.; Bhatt, S.; Aldissi, M. Changes in electrochemical impedance spectroscopy in protein biosensing. Anal. Chem. 2009, 81, 3944-3949. [CrossRef]

59. Pividori, M.I.; Merkoci, A.; Alegret, S. Electrochemical genosensor design: Immobilisation of oligonucleotides onto transducer surfaces and detection methods. Biosens. Bioelectron. 2000, 15, 291-303. [CrossRef]

60. Ferapontova, E.E. DNA electrochemistry and electrochemical sensors for nucleic acids. Annu. Rev. Anal. Chem. 2018, 11, 197-218. [CrossRef]

61. Ferapontova, E.E. Hybridization biosensors relying on electrical properties of nucleic acids. Electroanalysis 2017, 29, 6-13. [CrossRef]

62. Farjami, E.; Campos, R.; Nielsen, J.; Gothelf, K.; Kjems, J.; Ferapontova, E.E. RNA aptamer-based electrochemical biosensor for selective and label-free analysis of dopamine. Anal. Chem. 2013, 85, 121-128. [CrossRef]

63. Álvarez-Martos, I.; Ferapontova, E.E. Electrochemical label-free aptasensor for specific analysis of dopamine in serum in the presence of structurally related neurotransmitters. Anal. Chem. 2016, 88, 3608-3616. [CrossRef]

64. Oberhaus, F.V.; Frense, D.; Beckmann, D. Immobilization techniques for aptamers on gold electrodes for the electrochemical detection of proteins: A Review. Biosensors 2020, 10, 45. [CrossRef] [PubMed]

65. Zamay, G.S.; Zamay, T.N.; Kolovskii, V.A.; Shabanov, A.V.; Glazyrin, Y.E.; Veprintsev, D.V.; Krat, A.V.; Zamay, S.S.; Kolovskaya, O.S.; Gargaun, A.; et al. Electrochemical aptasensor for lung cancer-related protein detection in crude blood plasma samples. Sci. Rep. 2016, 6, 34350. [CrossRef] [PubMed]

66. Mazaafrianto, D.N.; Ishida, A.; Maeki, M.; Tani, H.; Tokeshi, M. Label-free electrochemical sensor for ochratoxin a using a microfabricated electrode with immobilized aptamer. ACS Omega 2018, 3, 16823-16830. [CrossRef]

67. Ding, S.; Mosher, C.; Lee, X.Y.; Das, S.R.; Cargill, A.A.; Tang, X.; Chen, B.; McLamore, E.S.; Gomes, C.L.; Hostetter, J.M.; et al. Rapid and label-free detection of interferon gamma via an electrochemical aptasensor comprised of a ternary surface monolayer on a gold interdigitated electrode array. ACS Sens. 2017, 2, 210-217. [CrossRef] [PubMed]

68. Su, Z.; Xu, H.; Xu, X.; Zhang, Y.; Ma, Y.; Li, C.; Xi, Q. Effective covalent immobilization of quinone and aptamer onto a gold electrode via thiol addition for sensitive and selective protein biosensing. Talanta 2017, 164, 244-248. [CrossRef] [PubMed] 
69. Jolly, P.; Formisano, N.; Tkáč, J.; Kasák, P.; Frost, C.G.; Estrela, P. Label-free impedimetric aptasensor with antifouling surface chemistry: A prostate specific antigen case study. Sens. Actuators B Chem. 2015, 209, 306-312. [CrossRef]

70. Liu, N.; Song, J.; Lu, Y.; Davis, J.J.; Gao, F.; Luo, X. Electrochemical aptasensor for ultralow fouling cancer cell quantification in complex biological media based on designed branched peptides. Anal. Chem. 2019, 91, 8334-8340. [CrossRef]

71. Jain, A.; Cheng, K. The principles and applications of avidin-based nanoparticles in drug delivery and diagnosis. J. Control. Release 2017, 245, 27-40. [CrossRef]

72. Pandey, A.K.; Rajput, Y.S.; Sharma, R.; Singh, D. Immobilized aptamer on gold electrode senses trace amount of aflatoxin M1. Appl. Nanosci. 2017, 7, 893-903. [PubMed]

73. Karapetis, S.; Nikolelis, D.; Hianik, T. Label-free and redox markers-based electrochemical aptasensors for Aflatoxin M1 detection. Sensors 2018, 18, 4218.

74. Tahiri-Alaoui, A.; Frigotto, L.; Manville, N.; Ibrahim, J.; Romby, P.; James, W. High affinity nucleic acid aptamers for streptavidin incorporated into bi-specific capture ligands. Nucleic Acids Res. 2002, 30, 10.

75. Li, Y.; Lu, Y. Functional Nucleic Acids for Analytical Applications, 3rd ed.; Springer: New York, NY, USA, 2009 ; pp. $179-199$.

76. De-los-Santos-Álvarez, P.; Lobo-Castañón, M.J.; Miranda-Ordieres, A.J.; Tuñón-Blanco, P. Current strategies for electrochemical detection of DNA with solid electrodes. Anal. Bioanal. Chem. 2004, 378, 104-118. [PubMed]

77. Jolly, P.; Batistuti, M.R.; Ustuner, S.; Mulato, M.; Arya, S.K.; Estrela, P. Chapter 9 Nucleic acid-based aptasensors for cancer diagnostics: An insight into immobilisation strategies. In Next Generation Point-of-Care Biomedical Sensors Technologies for Cancer Diagnosis; Chandra, P., Tan, Y.N., Singh, S.P., Eds.; Springer: Singapore, 2017; pp. 205-231.

78. Gan, X.; Zhao, H. Understanding signal amplification strategies of nanostructured electrochemical sensors for environmental pollutants. Curr. Opin. Electrochem. 2019, 17, 56-64.

79. Liu, J.; Morris, M.D.; Macazo, F.C.; Schoukroun-Barnes, L.R.; White, R.J. The current and future role of aptamers in electroanalysis. J. Electrochem. Soc. 2014, 161, H301-H313.

80. Wang, Z.; Yu, J.; Gui, R.; Jin, H.; Xia, Y. Carbon nanomaterials-based electrochemical aptasensors. Biosens. Bioelectron. 2016, 79, 136-149.

81. George, J.M.; Antony, A.; Mathew, B. Metal oxide nanoparticles in electrochemical sensing and biosensing: A review. Microchim. Acta 2018, 185, 358.

82. Gui, R.; Jin, H.; Guo, H.; Wang, Z. Recent advances and future prospects in molecularly imprinted polymers-based electrochemical biosensors. Biosens. Bioelectron. 2018, 100, 56-70.

83. Maduraiveeran, G.; Sasidharan, M.; Ganesan, V. Electrochemical sensor and biosensor platforms based on advanced nanomaterials for biological and biomedical applications. Biosens. Bioelectron. 2018, 103, 113-129.

84. Walcarius, A. Silica-based electrochemical sensors and biosensors: Recent trends. Curr. Opin. Electrochem. 2018, 10, 88-97. [CrossRef]

85. Pietrantonio, F.D.; Cannatà, D.; Benetti, M. Biosensor technologies based on nanomaterials. In Functional Nanostructured Interfaces for Environmental and Biomedical Applications, Micro and Nano Technologies, 3rd ed.; Dca, V., Suchea, M.P., Eds.; Elsevier: Oxford, UK, 2009; pp. 181-242.

86. Cho, I.H.; Kim, D.H.; Park, S. Electrochemical biosensors: Perspective on functional nanomaterials for on-site analysis. Biomater. Res. 2020, 24, 6. [CrossRef] [PubMed]

87. Idris, A.O.; Mamba, B.; Feleni, U. Poly (propylene imine) dendrimer: A potential nanomaterial for electrochemical application. Mater. Chem. Phys. 2020, 244, 122641. [CrossRef]

88. Negahdary, M. Electrochemical aptasensors based on the gold nanostructures. Talanta 2020, 216, 120999. [CrossRef]

89. Pan, M.; Yang, J.; Liu, K.; Yin, Z.; Ma, T.; Liu, S.; Xu, L.; Wang, S. Noble Metal Nanostructured Materials for Chemical and Biosensing Systems. Nanomaterials 2020, 10, 209. [CrossRef]

90. Nawaz, M.A.H.; Rauf, S.; Catanante, G.; Nawaz, M.H.; Nunes, G.; Marty, J.L.; Hayat, A. One step assembly of thin films of carbon nanotubes on screen printed interface for electrochemical aptasensing of breast cancer biomarker. Sensors 2016, $16,1651$. [CrossRef]

91. Dauphin-Ducharme, P.; Yang, K.; Arroyo-Curras, N.; Ploense, K.L.; Zhang, Y.; Gerson, J.; Kurnik, M.; Kippin, T.E.; Stojanovic, M.N.; Plaxco, K.W. Electrochemical aptamer-based sensors for improved therapeutic drug monitoring and high-precision, feedback-controlled drug delivery. ACS Sens. 2019, 4, 2832-2837. [CrossRef]

92. Zhang, X.; Duan, Y.F.S.; Su, L.; Zhang, J.; He, F. Mycobacterium tuberculosis strain H37Rv electrochemical sensor mediated by aptamer and AuNPs-DNA. ACS Sens. 2019, 4, 849-855. [CrossRef]

93. Amor-Gutiérrez, O.; Selvolini, G.; Fernández-Abedul, M.T.; Escosura-Muñiz, A.; Marrazza, G. Folding-based electrochemical aptasensor for the determination of $\beta$-lactoglobulin on poly-L-lysine modified graphite electrodes. Sensors 2020, $20,2349$. [CrossRef]

94. Villalonga, A.; Pérez-Calabuig, A.M.; Villalonga, R. Electrochemical biosensors based on nucleic acid aptamers. Anal. Bioanal. Chem. 2020, 412, 55-72. [CrossRef]

95. Song, S.; Wang, L.; Li, J.; Fan, C.; Zhao, J. Aptamer-based biosensors. Trends Anal. Chem. 2008, 27, 108-117. [CrossRef]

96. Plaxco, K.W.; Soh, H.T. Switch-based biosensors: A new approach towards real-time, in vivo molecular detection. Trends. Biotechnol. 2011, 29, 1-5. [CrossRef] [PubMed] 
97. Kaur, H.; Bruno, J.G.; Kumar, A.; Sharma, T.K. Aptamers in the therapeutics and diagnostics pipelines. Theranostics 2018, 8, 4016-4032. [CrossRef] [PubMed]

98. National Cancer Institute at the National Institutes of Health, NCI Dictionary of Cancer Terms. Available online: https: //www.cancer.gov/publications / dictionaries/cancer-terms/def/biomarker (accessed on 2 December 2020).

99. Duffy, M.J. Tumor Markers in Clinical Practice: A Review Focusing on Common Solid Cancers. Med. Princ. Pract. 2013, $22,4-11$. [CrossRef]

100. Yarden, S.; Sliwkowski, M.X. Untangling the ErbB signalling network. Nat. Rev. Mol. Cell Biol. 2001, 2, 127-137. [CrossRef]

101. Perez, E.A.; Cortés, J.; Gonzalez-Angulo, A.M.; Bartlett, J.M.S. HER2 testing: Current status and future directions. Cancer Treat. Rev. 2014, 40, 276-284. [CrossRef]

102. Ross, J.S.; Slodkowska, E.A.; Symmans, W.F.; Pusztai, L.; Ravdin, P.M.; Hortobagyi, G.N. The HER-2 receptor and breast cancer: Ten years of targeted anti-HER-2 therapy and personalized medicine. Oncologist 2009, 14, 320-368. [CrossRef]

103. Salimian, R.; Kékedy-Nagy, L.; Ferapontova, E.E. Specific picomolar detection of a breast cancer biomarker HER-2/neu protein in serum: Electrocatalytically amplified electroanalysis by the aptamer/PEG-modified electrode. ChemElectroChem 2017, 4, 872-879. [CrossRef]

104. Emami, M.; Shamsipur, M.; Saber, R.; Irajirad, R. An electrochemical immunosensor for detection of a breast cancer biomarker based on antiHER2-iron oxide nanoparticle bioconjugates. Analyst 2014, 139, 2858-2866. [CrossRef]

105. Zhu, Y.; Chandra, P.; Shim, Y.B. Ultrasensitive and selective electrochemical diagnosis of breast cancer based on a hydrazine-Au nanoparticle-aptamer bioconjugate. Anal. Chem. 2013, 85, 1058-1064. [CrossRef]

106. Al-Khafaji, Q.A.M.; Harris, M.; Tombelli, S.; Laschi, S.; Turner, A.P.F.; Mascini, M.; Marrazza, G. An electrochemical immunoassay for HER2 detection. Electroanalysis 2012, 24, 735-742. [CrossRef]

107. Malecka, K.; Pankratov, D.; Ferapontova, E.E. Femtomolar electroanalysis of a breast cancer biomarker HER-2/neu protein in human serum. Anal. Chim. Acta 2019, 1077, 140-149. [CrossRef] [PubMed]

108. Biliran, H.; Sheng, S. Pleiotrophic inhibition of pericellular urokinase-type plasminogen activator system by endogenous tumor suppressive maspin. Cancer Res. 2001, 61, 8676-8682. [PubMed]

109. Andreasen, P.A.; Egelund, R.; Petersen, H.H. The plasminogen activation system in tumor growth, invasion, and metastasis. Cell. Mol. Life Sci. 2000, 57, 25-40. [CrossRef] [PubMed]

110. Danø, K.; Behrendt, N.; Høyer-Hansen, G.; Johnsen, M.; Lund, L.R.; Ploug, M.; Rømer, J. Plasminogen activation and cancer. Thromb. Haemost. 2005, 93, 676-681.

111. Lang, D.S.; Heilenkötter, U.; Schumm, W.; Behrens, O.; Simon, R.; Vollmer, E.; Goldmann, T. Optimized immunohistochemistry in combination with image analysis: A reliable alternative to quantitative ELISA determination of uPA and PAI-1 for routine risk group discrimination in breast cancer. Breast 2013, 22, 736-743. [CrossRef]

112. Fowler, C.B.; Man, Y.G.; Mason, J.T. An Ultra-sensitive immunoassay for quantifying biomarkers in breast tumor Tissue. J. Cancer 2014, 5, 115-124. [CrossRef]

113. Hofmann, R.; Lehmer, A.; Hartung, R.; Robrecht, C.; Buresch, M.; Grothe, F. Prognostic value of urokinase plasminogen activator and plasminogen activator inhibitor-1 in renal cell cancer. J. Urol. 1996, 155, 858-862. [CrossRef]

114. Jarczewska, M.; Kekedy-Nagy, L.; Nielsen, J.S.; Campos, R.; Kjems, J.; Malinowska, E.; Ferapontova, E.E. Electroanalysis of pM-levels of urokinase plasminogen activator in serum by phosphorothioated RNA aptamer. Analyst 2015, 140, $3794-3802$. [CrossRef]

115. Campos, R.; Kotlyar, A.; Ferapontova, E.E. DNA-mediated electron transfer in DNA duplexes tethered to gold electrodes via phosphorothioated dA tags. Langmuir 2014, 30, 11853-11857. [CrossRef]

116. Ferapontova, E.E.; Gothelf, K.V. Effect of serum on an RNA aptamer-based electrochemical sensor for theophylline. Langmuir 2009, 25, 4279-4283. [CrossRef] [PubMed]

117. Hao, C.; Cui, Y.; Owen, S.; Li, W.; Cheng, S.; Jiang, W.G. Human osteopontin: Potential clinical applications in cancer. Int. J. Mol. Med. 2017, 39, 1327-1337. [CrossRef]

118. Wei, R.; Wong, J.P.C.; Kwok, H.F. Osteopontin-A promising biomarker for cancer therapy. J. Cancer 2017, 8, 2173-2183. [CrossRef] [PubMed]

119. Anborgh, P.H.; Lee, D.J.; Stam, P.F.; Tuck, A.B.; Chambers, A.F. Role of osteopontin as a predictive biomarker for anti-EGFR therapy in triple-negative breast cancer. Expert Opin. Ther. Targets 2018, 22, 727-734. [CrossRef] [PubMed]

120. Lan, Z.; Fu, D.; Yu, X.; Xi, M. Diagnostic values of osteopontin combined with CA125 for ovarian cancer: A meta-analysis. Fam. Cancer 2016, 15, 221-230. [CrossRef]

121. Wiśniewski, T.; Żyromska, A.; Makarewicz, R.; Żekanowska, E. Osteopontin and angiogenic factors as new biomarkers of prostate cancer. Urol. J. 2018, 16, 134-140.

122. Chakraborty, D.; Viveka, T.S.; Arvind, K.; Shyamsundar, V.; Kanchan, M.; Alex, S.A.; Chandrasekaran, N.; Vijayalakshmi, R.; Mukherjee, A. A facile gold nanoparticle-based ELISA system for detection of osteopontin in saliva: Towards oral cancer diagnostics. Clin. Chim. Acta 2018, 477, 166-172. [CrossRef]

123. Yan, C.H.; Lv, M.; Li, H.; Song, X.; Yan, F.; Cao, S.; Ren, X. Osteopontin is a novel prognostic biomarker in early-stage non-small cell lung cancer after surgical resection. J. Cancer Res. Clin. Oncol. 2015, 141, 1371-1378. [CrossRef]

124. Bruha, R.; Vitek, L.; Smid, V. Osteopontin-A potential biomarker of advanced liver disease. Ann. Hepatol. 2020, 19, 344-352. [CrossRef] 
125. Gu, X.; Gao, X.S.; Ma, M.; Qin, S.; Qi, X.; Li, X.; Sun, S.; Yu, H.; Wang, W.; Zhou, D. Prognostic significance of osteopontin expression in gastric cancer: A meta-analysis. Oncotarget 2016, 7, 69666-69673. [CrossRef]

126. Rychlíkováa, J.; Veckaa, M.; Jáchymováb, M.; Macášeka, J.; Hrabáka, P.; Zemana, M.; Vávrováa, L.; Šoupalc, J.; Krechlera, T.; Žák, A. Osteopontin as a discriminating marker for pancreatic cancer and chronic pancreatitis. Cancer Biomark. 2016, 17, 55-65.

127. Assidi, M.; Gomaa, W.; Jafri, M.; Hanbazazh, M.; Al-Ahwal, M.; Pushparaj, P.; Al-Harbi, A.; Al-Qahtani, M.; Buhmeida, A.; Al-Maghrabi, J. Prognostic value of Osteopontin (SPP1) in colorectal carcinoma requires a personalized molecular approach. Tumor Biol. 2019, 41, 1-11.

128. Zhao, M.; Xu, H.; Liang, F.; He, J.; Zhang, J. Association of osteopontin expression with the prognosis of glioma patient: A meta-analysis. Tumor Biol. 2015, 36, 429-436.

129. Guarino, V.; Faviana, P.; Salvatore, G.; Castellone, M.D.; Cirafici, A.M.; De Falco, V.; Celetti, A.; Giannini, R.; Basolo, F.; Melillo, R.M.; et al. Osteopontin Is Overexpressed in Human Papillary Thyroid Carcinomas and Enhances Thyroid Carcinoma Cell Invasiveness. J. Clin. Endocrinol. Metab. 2005, 90, 5270-5278. [PubMed]

130. Kiss, T.; Ecsedi, S.; Vizkeleti, L.; Koroknai, V.; Emri, G.; Kovács, N.; Adany, R.; Balazs, M. The role of osteopontin expression in melanoma progression. Tumor Biol. 2015, 36, 7841-7847.

131. Primasari, M.; Soehartati, A.; Gondhowiardjo, A.; Handjari, D.R.; Matondang, S.; Kantaatmadja, A.B. Osteopontin level correlates negatively with tumor shrinkage in neoadjuvant chemoradiation of locally advanced rectal cancer. Adv. Mod. Oncol. Res. 2015, 1, $56-61$.

132. Cao, Y.; Chen, D.; Chen, W.; Yu, J.; Chen, Z.; Li, G. Aptamer-based homogeneous protein detection using cucurbit[7]uril functionalized electrode. Anal. Chim. Acta 2014, 812, 45-49.

133. Meirinho, S.G.; Dias, L.G.; Peres, A.M.; Rodrigues, L.R. Development of an electrochemical RNA-aptasensor to detect human osteopontin. Biosens. Bioelectron. 2015, 71, 332-341.

134. Meirinho, S.G.; Dias, L.G.; Peres, A.M.; Rodrigues, L.R. Electrochemical aptasensor for human osteopontin detection using a DNA aptamer selected by SELEX. Anal. Chim. Acta 2017, 987, 25-37.

135. Zhou, S.; Gu, C.; Li, Z.; Yang, L.; He, L.; Wang, M.; Huang, X.; Zhou, N.; Zhang, Z. Ti3C2Tx MXene and polyoxometalate nanohybrid embedded with polypyrrole: Ultra-sensitive platform for the detection of osteopontin. Appl. Surf. Sci. 2019, 498, 143889.

136. Zhou, S.; Hu, M.; Huang, X.; Zhou, N.; Zhang, Z.; Wang, M.; Liu, Y.; He, L. Electrospun zirconium oxide embedded in graphenelike nanofiber for aptamer-based impedimetric bioassay toward osteopontin determination. Microchim. Acta 2020, $187,219$. [CrossRef] [PubMed]

137. Li, X.; Xu, Y.; Zhang, L. Serum CA153 as biomarker for cancer and noncancer diseases. Prog. Mol. Biol. Transl. Sci. 2019, 162, 265-276. [PubMed]

138. Nath, S.; Mukherjee, P. MUC1: A multifaceted oncoprotein with a key role in cancer progression. Trends Mol. Med. 2014, 20, 332-342. [CrossRef] [PubMed]

139. Kufe, D.W. Mucins in cancer: Function, prognosis and therapy. Nat. Rev. Cancer 2009, 9, 874-885. [CrossRef] [PubMed]

140. Bastu, E.; Mutlu, M.F.; Yasa, C.; Dural, O.; Nehir, A.A.; Celik, C.; Buyru, F.; Yeh, J. Role of Mucin 1 and Glycodelin A in recurrent implantation failure. Fertil. Steril. 2015, 103, 1059-1064. [CrossRef] [PubMed]

141. Chen, X.; Zhang, Q.; Qian, C.; Hao, N.; Xu, L.; Yao, C. Electrochemical aptasensors for mucin1 based on dual signal amplification of poly(o-phenylenediamine) carrier and functionalized carbon nanotubes tracing tag. Biosens. Bioelectron. 2015, 64, 485-492. [CrossRef]

142. Liu, X.; Qin, Y.; Deng, C.; Xiang, J.; Li, Y. A simple and sensitive impedimetric aptasensors for the detection of tumor markers based on gold nanoparticles signal amplification. Talanta 2015, 132, 150-154. [CrossRef]

143. Wang, H.; Sun, J.; Lu, L.; Yang, X.; Xia, J.; Zhang, F.; Wang, Z. Competitive electrochemical aptasensor based on a cDNAferrocene/MXene probe for detection of breast cancer marker Mucin1. Anal. Chim. Acta 2020, 1094, 18-25. [CrossRef]

144. Gupta, P.; Bharti, A.; Kaur, N.; Singh, S.; Prabhakar, N. An electrochemical aptasensor based on gold nanoparticles and graphene oxide doped poly(3,4-ethylenedioxythiophene) nanocomposite for detection of MUC1. J. Electroanal. Chem. 2018, 813, 102-108. [CrossRef]

145. Karpik, A.E.; Crulhas, B.P.; Rodrigues, C.B.; Castro, G.R.; Pedrosa, V.A. Aptamer-based biosensor developed to monitor MUC1 released by prostate cancer cells. Electroanalysis 2017, 29, 2246-2253. [CrossRef]

146. Florea, A.; Ravalli, A.; Cristea, C.; Săndulescu, R.; Marrazza, G. An optimized bioassay for Mucin1 detection in serum samples. Electroanalysis 2015, 27, 1594-1601. [CrossRef]

147. Wen, W.; Hu, R.; Bao, T.; Zhang, X.; Wang, S. An insertion approach electrochemical aptasensor for mucin 1 detection based on exonuclease-assisted target recycling. Biosens. Bioelectron. 2015, 71, 13-17. [CrossRef] [PubMed]

148. Farzin, L.; Sadjadi, S.; Shamsipur, M.; Chabok, A.; Sheibani, S. A sandwich-type electrochemical aptasensor for determination of MUC 1 tumor marker based on PSMA-capped PFBT dots platform and high conductive rGO-N'(1), $\mathrm{N}^{\prime}(3)-$ dihydroxymalonimidamide/thionine nanocomposite as a signal tag. J. Electroanal. Chem. 2017, 807, 108-118. [CrossRef]

149. Song, J.; Zhou, Y.; Chen, B.; Lou, W.; Gu, J. Development of electrochemical aptamer biosensor for tumor marker MUC1 determination. Int. J. Electrochem. Sci. 2017, 12, 5618-5627. [CrossRef] 
150. Wang, M.; Hu, B.; Ji, H.; Song, Y.; Liu, J.; Peng, D.; He, L.; Zhang, Z. Aptasensor based on hierarchical core-shell nanocomposites of zirconium hexacyanoferrate nanoparticles and mesoporous $\mathrm{mFe}_{3} \mathrm{O}_{4} @ \mathrm{mC}$ : Electrochemical quantitation of epithelial tumor marker Mucin-1. ACS Omega 2017, 2, 6809-6818. [CrossRef]

151. Lin, C.; Zheng, H.; Huang, Y.; Chen, Z.; Luo, F.; Wang, J.; Guo, L.; Qiu, B.; Lin, Z.; Yang, H. Homogeneous electrochemical aptasensor for mucin 1 detection based on exonuclease I-assisted target recycling amplification strategy. Biosens. Bioelectron. 2018, 117, 474-479. [CrossRef]

152. Ma, C.; Liu, H.; Zhang, L.; Li, H.; Yan, M.; Song, X.; Yu, J. Multiplexed aptasensor for simultaneous detection of carcinoembryonic antigen and mucin- 1 based on metal ion electrochemical labels and $\mathrm{Ru}\left(\mathrm{NH}_{3}\right)_{6}{ }^{3+}$ electronic wires. Biosens. Bioelectron. 2018, 99, 8-13. [CrossRef]

153. Zheng, J.; Peng, X.; Wang, Y.; Bao, T.; Wen, W.; Zhang, X.; Wang, S. An exonuclease-assisted triple-amplified electrochemical aptasensor for mucin 1 detection based on strand displacement reaction and enzyme catalytic strategy. Anal. Chim. Acta 2019, 1086, 75-81. [CrossRef] [PubMed]

154. Aithal, A.; Rauth, S.; Kshirsagar, P.; Shah, A.; Lakshmanan, I.; Junker, W.M.; Jain, M.; Ponnusamy, M.P.; Batra, S.K. MUC16 as a novel target for cancer therapy. Expert Opin. Ther. Targets 2018, 22, 675-686. [CrossRef]

155. Suh, H.; Valle, S.; Morris, D.L. Targeting MUC16 in cancer therapy. Chemother. Open Access 2017, 6, 235. [CrossRef]

156. Milman, S.; Whitney, K.D.; Fleischer, N. Metastatic medullary thyroid cancer presenting with elevated levels of CA 19-9 and CA 125. Thyroid 2011, 21, 913-916. [CrossRef]

157. Bast Jr, R.C.; Feeney, M.; Lazarus, H.; Nadler, L.M.; Colvin, R.B.; Knapp, R.C. Reactivity of a monoclonal antibody with human ovarian carcinoma. J. Clin. Investig. 1981, 68, 1331-1337. [CrossRef] [PubMed]

158. Chen, F.; Shen, J.; Wang, J.; Cai, P.; Huang, Y. Clinical analysis of four serum tumor markers in 458 patients with ovarian tumors: Diagnostic value of the combined use of HE4, CA125, CA19-9, and CEA in ovarian tumors. Cancer Manag. Res. 2018, 10, 1313-1318. [CrossRef] [PubMed]

159. Majd, S.M.; Salimi, A. Ultrasensitive flexible FET-type aptasensor for CA 125 cancer marker detection based on carboxylated multiwalled carbon nanotubes immobilized onto reduced graphene oxide film. Anal. Chim. Acta 2018, 1000, 273-282. [CrossRef] [PubMed]

160. Chen, J.; Hu, W.; Wei, J.; Yu, F.; Wu, L.; Wang, C.; Wang, W.; Zuo, S.; Shang, B.; Chen, Q. An electrochemical aptasensing platform for carbohydrate antigen 125 based on the use of flower-like gold nanostructures and target-triggered strand displacement amplification. Microchim. Acta 2019, 186, 388. [CrossRef] [PubMed]

161. Farzin, L.; Sadjadi, S.; Shamsipur, M.; Sheibani, S.; Mousazadeh, M.H. Employing AgNPs doped amidoxime-modified polyacrylonitrile (PANoxime) nanofibers for target induced strand displacement-based electrochemical aptasensing of CA125 in ovarian cancer patients. Mater. Sci. Eng. C 2019, 97, 679-687. [CrossRef] [PubMed]

162. Wang, M.; Hu, M.; Li, Z.; He, L.; Song, Y.; Jia, Q.; Zhang, Z.; Du, M. Construction of Tb-MOF-on-Fe-MOF conjugate as a novel platform for ultrasensitive detection of carbohydrate antigen 125 and living cancer cells. Biosens. Bioelectron. 2019, 142, 111536. [CrossRef] [PubMed]

163. Lu, L.; Liu, B.; Leng, J.; Ma, X.; Peng, H. Electrochemical mixed aptamer-antibody sandwich assay for mucin protein 16 detection through hybridization chain reaction amplification. Anal. Bioanal. Chem. 2020, 412, 7169-7178. [CrossRef]

164. Sadasivam, M.; Sakthivel, A.; Nagesh, N.; Hansda, S.; Veerapandian, M.; Alwarappan, S.; Manickam, P. Magnetic bead-amplified voltammetric detection for carbohydrate antigen 125 with enzyme labels using aptamer-antigen-antibody sandwiched assay. Sens. Actuators B Chem. 2020, 312, 127985. [CrossRef]

165. Niu, G.; Chen, X. Vascular endothelial growth factor as an anti-angiogenic target for cancer therapy. Curr. Drug Targets 2010, 11, 1000-1017. [CrossRef]

166. Goel, H.L.; Mercurio, A.M. VEGF targets the tumour cell. Nat. Rev. Cancer 2013, 13, 871-882. [CrossRef] [PubMed]

167. Razy, N.H.M.P.; Rahman, W.F.W.A.; Win, T.T. Expression of Vascular Endothelial Growth Factor and Its Receptors in Thyroid Nodular Hyperplasia and Papillary Thyroid Carcinoma: A Tertiary Health Care Centre Based Study. Asian Pac. J. Cancer Prev. 2019, 20, 277-282. [CrossRef] [PubMed]

168. Ławicki, S.; Będkowska, G.E.; Gacuta-Szumarska, E.; Szmitkowski, M. The plasma concentration of VEGF, HE4 and CA125 as a new biomarkers panel in different stages and sub-types of epithelial ovarian tumors. J. Ovarian Res. 2013, 6, 45. [CrossRef] [PubMed]

169. Shamsipur, M.; Farzin, L.; Tabrizi, M.A.; Molaabasi, F. Highly sensitive label free electrochemical detection of VGEF165 tumor marker based on "signal off" and "signal on" strategies using an anti-VEGF165 aptamer immobilized BSA-gold nanoclusters/ionic liquid/ glassy carbon electrode. Biosens. Bioelectron. 2015, 74, 369-375. [CrossRef]

170. Dehghani, S.; Nosrati, R.; Yousefi, M.; Nezami, A.; Soltani, F.; Taghdisi, S.M.; Abnous, K.; Alibolandi, M.; Ramezani, M. Aptamerbased biosensors and nanosensors for the detection of vascular endothelial growth factor (VEGF): A review. Biosens. Bioelectron. 2018, 110, 23-37. [CrossRef]

171. Wei, T.; Dong, T.; Xing, H.; Liu, Y.; Dai, Z. Cucurbituril and azide co-functionalized graphene oxide for ultrasensitive electro-click biosensing. Anal. Chem. 2017, 89, 12237-12243. [CrossRef]

172. Ye, H.; Qin, B.; Sun, Y.; Li, J. Electrochemical detection of VEGF165 lung cancer marker based on Au-Pd alloy assisted aptasensor. Int. J. Electrochem. Sci. 2017, 12, 818-1828. 
173. Hongxia, C.; Zaijun, L.; Ruiyi, L.; Guangli, W.; Zhiguo, G. Molecular machine and gold/graphene quantum dot hybrid based dual amplification strategy for voltammetric detection of VEGF165. Microchim. Acta 2019, 186, 242. [CrossRef]

174. Wang, H.; Ma, Y.; Guo, C.; Yang, Y.; Peng, Z.; Liu, Z.; Zhang, Z. Templated seed-mediated derived Au nanoarchitectures embedded with nanochitosan: Sensitive electrochemical aptasensor for vascular endothelial growth factor and living MCF-7 cell detection. Appl. Surf. Sci. 2019, 481, 505-514. [CrossRef]

175. Ni, S.; Qiao, L.; Shen, Z.; Gao, Y.; Liu, G. Physical absorption vs covalent binding of graphene oxide on glassy carbon electrode towards a robust aptasensor for ratiometric electrochemical detection of vascular endothelial growth factor (VEGF) in serum. Electrochim. Acta 2020, 331, 135321. [CrossRef]

176. Ni, S.; Shen, Z.; Zhang, P.; Liu, G. Enhanced performance of an electrochemical aptasensor for real-time detection of vascular endothelial growth factor (VEGF) by nanofabrication and ratiometric measurement. Anal. Chim. Acta 2020, 1121, 74-82. [CrossRef] [PubMed]

177. Lee, J.; Tatsumi, A.; Tsukakoshi, K.; Wilson, E.D.; Abe, K.; Sode, K.; Ikebukuro, K. Application of a glucose dehydrogenase-fused with zinc finger protein to label DNA aptamers for the electrochemical detection of VEGF. Sensors 2020, 20, 3878. [CrossRef]

178. Feng, Y.; Xiao, S.; Xiong, X.; Wang, H.; Kong, F.; Li, Y.; Zhang, Y.; Chen, L. An impedimetric aptasensor based on a novel line-pad-line electrode for the determination of VEGF165. Electroanalysis 2020, 32, 1843-1849. [CrossRef]

179. Qureshi, A.; Gurbuz, Y.; Niazi, J.H. Capacitive aptamer-antibody based sandwich assay for the detection of VEGF cancer biomarker in serum. Sens. Actuators B Chem. 2015, 209, 645-651. [CrossRef]

180. Ravalli, A.; Rivas, L.; De la Escosura-Muñiz, A.; Pons, J.; Merkoçi, A.; Marrazza, G. A DNA aptasensor for electrochemical detection of vascular endothelial growth factor. J. Nanosci. Nanotechnol. 2015, 15, 3411-3416. [CrossRef]

181. Tabrizi, M.A.; Shamsipur, M.; Farzin, L. A high sensitive electrochemical aptasensor for the determination of VEGF165 in serum of lung cancer patient. Biosens. Bioelectron. 2015, 74, 764-769. [CrossRef]

182. Feng, L.; Lyu, Z.; Offenhäusser, A.; Mayer, D. Electrochemically triggered aptamer immobilization via click reaction for vascular endothelial growth factor detection. Eng. Life Sci. 2016, 16, 550-559. [CrossRef]

183. Fu, X.-M.; Liu, Z.-J.; Cai, S.-X.; Zhao, Y.-P.; Wu, D.-Z.; Li, C.-Y.; Chen, J.-H. Electrochemical aptasensor for the detection of vascular endothelial growth factor (VEGF) based on DNA-templated Ag/Pt bimetallic nanoclusters. Chin. Chem. Lett. 2016, 27, 920-926. [CrossRef]

184. Crulhas, B.P.; Karpik, A.E.; Delella, F.K.; Castro, G.R.; Pedrosa, V.A. Electrochemical aptamer-based biosensor developed to monitor PSA and VEGF released by prostate cancer cells. Anal. Bioanal. Chem. 2017, 409, 6771-6780. [CrossRef]

185. Tabrizi, M.A.; Shamsipur, M.; Saber, R.; Sarkar, S. Simultaneous determination of CYC and VEGF165 tumor markers based on immobilization of flavin adenine dinucleotide and thionine as probes on reduced graphene oxide-poly(amidoamine)/gold nanocomposite modified dual working screen-printed electrode. Sens. Actuators B Chem. 2017, 240, 1174-1181. [CrossRef]

186. Rawla, P. Epidemiology of prostate cancer. World J. Oncol. 2019, 10, 63-89. [CrossRef]

187. Diamandis, E.P. Prostate-specific antigen: A cancer fighter and a valuable messenger? Clin. Chem. 2000, 46, 896-900. [CrossRef]

188. Ankerst, D.P.; Thompson, I.M. Sensitivity and specificity of prostate-specific antigen for prostate cancer detection with high rates of biopsy verification. Arch. Ital. Urol. Androl. 2006, 78, 125-129.

189. Healy, D.A.; Hayes, C.J.; Leonard, P.; McKenna, L.; O’Kennedy, R. Biosensor developments: Application to prostate-specific antigen detection. Trends Biotechnol 2007, 25, 125-131. [CrossRef] [PubMed]

190. Moradi, A.; Srinivasan, S.; Clements, J.; Batra, J. Beyond the biomarker role: Prostate-specific antigen (PSA) in the prostate cancer microenvironment. Cancer Metastasis Rev. 2019, 38, 333-346. [CrossRef] [PubMed]

191. Duffy, M.J. Biomarkers for prostate cancer: Prostate-specific antigen and beyond. Clin. Chem. Lab. Med. 2020, 58, 326-339. [CrossRef]

192. Jolly, P.; Formisano, N.; Estrela, P. DNA aptamer-based detection of prostate cancer. Chem. Pap. 2015, 69, 77-89. [CrossRef]

193. Damborska, D.; Bertok, T.; Dosekova, E.; Holazova, A.; Lorencova, L.; Kasak, P.; Tkac, J. Nanomaterial-based biosensors for detection of prostate specific antigen. Microchim. Acta 2017, 184, 3049-3067. [CrossRef] [PubMed]

194. Najeeb, M.A.; Ahmad, Z.; Shakoor, R.A.; Mohamed, A.M.A.; Kahraman, R. A novel classification of prostate specific antigen (PSA) biosensors based on transducing elements. Talanta 2017, 168, 52-61. [CrossRef]

195. Chang, Y.; Wang, M.; Wang, L.; Xia, N. Recent Progress in electrochemical biosensors for detection of prostate-specific antigen. Int. J. Electrochem. Sci. 2018, 13, 4071-4084. [CrossRef]

196. Xu, L.; Wen, Y.; Pandit, S.; Mokkapati, V.R.S.S.; Mijakovic, I.; Li, Y.; Ding, M.; Ren, S.; Li, W.; Liu, G. Graphene-based biosensors for the detection of prostate cancer protein biomarkers: A review. BMC Chem. 2019, 13, 112. [CrossRef]

197. Negahdary, M.; Sattarahmady, N.; Heli, H. Advances in prostate specific antigen biosensors-impact of nanotechnology. Clin. Chim. Acta 2020, 504, 43-55. [CrossRef] [PubMed]

198. Perry, G.; Cortezon-Tamarit, F.; Pascu, S.I. Detection and monitoring prostate specific antigen using nanotechnology approaches to biosensing. Front. Chem. Sci. Eng. 2020, 14, 4-18. [CrossRef]

199. Traynor, S.M.; Pandey, R.; Maclachlan, R.; Hosseini, A.; Didar, T.F.; Li, F.; Soleymani, L. Review-Recent advances in electrochemical detection of Prostate Specific Antigen (PSA) in clinically-relevant samples. J. Electrochem. Soc. 2020, $167,037551$. [CrossRef]

200. Zhang, G.; Liu, Z.; Fan, L.; Guo, Y. Electrochemical prostate specific antigen aptasensor based on hemin functionalized grapheneconjugated palladium nanocomposites. Microchim. Acta 2018, 185, 159. [CrossRef] 
201. Jalalvand, A.R. Fabrication of a novel and ultrasensitive label-free electrochemical aptasensor for detection of biomarker prostate specific antigen. Int. J. Biol. Macromol. 2019, 126, 1065-1073. [CrossRef] [PubMed]

202. Hassani, S.; Maghsoudi, A.S.; Akmal, M.R.; Rahmani, S.; Sarihi, P.; Ganjali, M.R.; Norouzi, P.; Abdollahi, M. A sensitive aptamerbased biosensor for electrochemical quantification of PSA as a specific diagnostic marker of prostate cancer. J. Pharm. Pharm. Sci. 2020, 23, 243-258. [CrossRef] [PubMed]

203. Soleimani, S.; Arkan, E.; Jalalvand, A.R.; Goicoechea, H.C. Fabrication of a novel electrochemical aptasensor assisted by a novel computerized monitoring system for real-time determination of the prostate specific antigen: A computerized experimental method brought elegancy. Microchem. J. 2020, 157, 104898. [CrossRef]

204. Zhao, Y.; Liu, H.; Shi, L.; Zheng, W.; Jing, X. Electroactive $\mathrm{Cu}_{2} \mathrm{O}$ nanoparticles and Ag nanoparticles driven ratiometric electrochemical aptasensor for prostate specific antigen detection. Sens. Actuators B Chem. 2020, 315, 128155. [CrossRef]

205. Raica, M.; Cimpean, A.M. Platelet-Derived Growth Factor (PDGF)/PDGF receptors (PDGFR) axis as target for antitumor and antiangiogenic therapy. Pharmaceuticals 2010, 3, 572-599. [CrossRef] [PubMed]

206. Aryal, B.; Yamakuchi, M.; Shimizu, T.; Kadono, J.; Furoi, A.; Gejima, K.; Komokata, T.; Koriyama, C.; Hashiguchi, T.; Imoto, Y Predictive value of diminished serum PDGF-BB after curative resection of hepatocellular cancer. J. Oncol. 2019, 6, 1-8. [CrossRef] [PubMed]

207. Razmi, N.; Baradaran, B.; Hejazi, M.; Hasanzadeh, M.; Mosafer, J.; Mokhtarzadeh, A.; De la Guardia, M. Recent advances on aptamer-based biosensors to detection of platelet derived growth factor. Biosens. Bioelectron. 2018, 113, 58-71. [CrossRef] [PubMed]

208. Fang, L.X.; Huang, K.J.; Liu, Y. Novel electrochemical dual-aptamer-based sandwich biosensor using molybdenum disulfide/carbon aerogel composites and Au nanoparticles for signal amplification. Biosens. Bioelectron. 2015, 71, 171-178. [CrossRef]

209. Lee, J.S.; Kim, W.; Cho, S.; Jun, J.; Cho, K.H.; Jang, J. Multidimensional hybrid conductive nanoplate-based aptasensor for platelet-derived growth factor detection. J. Mater. Chem. B 2016, 4, 4447-4454. [CrossRef] [PubMed]

210. Zhang, Z.; Guo, C.; Zhang, S.; He, L.; Wang, M.; Peng, D.; Tian, J.; Fang, S. Carbon based nanocomposites with aptamer-templated silver nanoclusters for the highly sensitive and selective detection of platelet-derived growth factor. Biosens. Bioelectron. 2017, 89, 735-742. [CrossRef]

211. Degefa, T.H.; Kwak, J. Label-free aptasensor for platelet-derived growth factor (PDGF) protein. Anal. Chim. Acta 2008, 613, 163-168. [CrossRef]

212. Lai, R.Y.; Plaxco, K.W.; Heeger, A.J. Aptamer-based electrochemical detection of picomolar platelet-derived growth factor directly in blood serum. Anal. Chem. 2007, 79, 229-233. [CrossRef]

213. Wang, Y.-H.; Chen, Y.-X.; Wu, X.; Huang, K.-J. Electrochemical biosensor based on Se-doped MWCNTs-graphene and Y shaped DNA-aided target-triggered amplification strategy. Colloids Surf. B 2018, 172, 407-413. [CrossRef]

214. Kim, W.; Lee, J.S.; Jang, J. Aptamer-functionalized three-dimensional carbon nanowebs for ultrasensitive and free-standing PDGF biosensor. ACS Appl. Mater. Interfaces 2020, 12, 20882-20890. [CrossRef]

215. Hu, X.; Zhang, S.B.; Lu, J.L.; Zheng, L.Y.; Geng, H.E.; Qiu, Y.Q.; Huang, Y.Y.; Qiu, L.P.; Chen, Y.D. Structure-switching hairpin probe based electrochemical aptasensor for highly sensitive detection of protein. In 5th International Conference on Advanced Design and Manufacturing Engineering; Jiang, Z., Ed.; Atlantis Press: Zhengzhou, China, 2015.

216. Huang, K.-J.; Liu, Y.-J.; Zhai, Q.-F. Ultrasensitive biosensing platform based on layered vanadium disulfide-graphene composites coupling with tetrahedron-structured DNA probes and exonuclease III assisted signal amplification. J. Mater. Chem. B 2015, 3, 8180-8187. [CrossRef]

217. Liu, X.; Shuai, H.-L.; Huang, K.-J. A label-free electrochemical aptasensor based on leaf-like vanadium disulfide-Au nanoparticles for the sensitive and selective detection of platelet-derived growth factor BB. Anal. Methods 2015, 7, 8277-8284. [CrossRef]

218. Zhang, S.; Hu, X.; Yang, X.; Sun, Q.; Xu, X.; Liu, X.; Shen, G.; Lu, J.; Shen, G.; Yu, R. Background eliminated signal-on electrochemical aptasensing platform for highly sensitive detection of protein. Biosens. Bioelectron. 2015, 66, 363-369. [CrossRef] [PubMed]

219. Fang, S.; Dong, X.; Liu, S.; Penng, D.; He, L.; Wang, M.; Fu, G.; Feng, X.; Zhang, Z. A label-free multi-functionalized electrochemical aptasensor based on $\mathrm{Fe}_{3} \mathrm{O}_{4} @ 3 \mathrm{D}-\mathrm{rGO} @$ plasma-polymerized (4-vinyl pyridine) nanocomposite for the sensitive detection of proteins in whole blood. Electrochim. Acta 2016, 212, 1-9. [CrossRef]

220. He, L.; Zhang, S.; Ji, H.; Wang, M.; Peng, D.; Yan, F.; Fang, S.; Zhang, H.; Jia, C.; Zhang, Z. Protein-templated cobaltous phosphate nanocomposites for the highly sensitive and selective detection of platelet-derived growth factor-BB. Biosens. Bioelectron. 2016, 79, 553-560. [CrossRef] [PubMed]

221. Huang, K.-J.; Shuai, H.-L.; Zhang, J.-Z. Ultrasensitive sensing platform for platelet-derived growth factor BB detection based on layered molybdenum selenide-graphene composites and Exonuclease III assisted signal amplification. Biosens. Bioelectron. 2016, 77, 69-75. [CrossRef]

222. Lin, M.-Y.; Hsu, W.-Y.; Yang, Y.-S.; Huang, J.-W.; Chung, Y.-L.; Chen, H. Immobilized rolling circle amplification on extended-gate field-effect transistors with integrated readout circuits for early detection of platelet-derived growth factor. Anal. Bioanal. Chem. 2016, 408, 4785-4797. [CrossRef] [PubMed]

223. Jiang, W.; Tian, D.; Zhang, L.; Guo, Q.; Cui, Y.; Yang, M. Dual signal amplification strategy for amperometric aptasensing using hydroxyapatite nanoparticles. Application to the sensitive detection of the cancer biomarker platelet-derived. Microchim. Acta 2017, 184, 4375-4381. [CrossRef] 
224. Xie, B.; Zhou, N.; Ding, R.; Zhao, Y.; Zhang, B.; Li, T.; Yang, M. Dual signal amplification strategy for electrochemical detection of platelet-derived growth factor BB. Anal. Methods 2017, 9, 6569-6573. [CrossRef]

225. Yu, Y.; Su, G.; Zhu, H.; Zhu, Q.; Chen, Y.; Xu, B.; Li, Y.; Zhang, W. Proximity hybridization-mediated isothermal exponential amplification for ultrasensitive electrochemical protein detection. Int. J. Nanomed. 2017, 12, 5903-5914. [CrossRef]

226. Zhao, C.-L.; Hua, M.; Yang, C.-Y.; Yang, Y.-H. A novel aptasensor based on 3D inorganic hybrid composite as immobilized substrate for sensitive detection of platelet-derived growth factor. Chin. Chem. Lett. 2017, 28, 1417-1423. [CrossRef]

227. Hasanzadeh, M.; Razmi, N.; Mokhtarzadeh, A.; Shadjou, N.; Mahboob, S. Aptamer based assay of plated-derived grow factor in unprocessed human plasma sample and MCF-7 breast cancer cell lysates using gold nanoparticle supported $\alpha$-cyclodextrin. Int. J. Biol. Macromol. 2018, 108, 69-80. [CrossRef] [PubMed]

228. Naz, Z.; Usman, S.; Saleem, K.; Ahmed, S.; Bashir, H.; Bilal, M.; Sumrin, A. Alpha-fetoprotein: A fabulous biomarker in hepatocellular, gastric and rectal cancer diagnosis. Biomed. Res. 2018, 29, 2478-2483. [CrossRef]

229. Liu, Y.; Deng, Y.; Li, T.; Chen, Z.; Chen, H.; Li, S.; Liu, H. Aptamer-Based Electrochemical Biosensor for Mercury Ions Detection Using AuNPs-Modified Glass Carbon Electrode. J. Biomed. Nanotechnol. 2018, 14, 2156-2161. [CrossRef] [PubMed]

230. Sauzay, C.; Petit, A.; Bourgeois, A.; Barbare, J.; Chauffert, B.; Galmiche, A.; Houessinon, A. Alpha-foetoprotein (AFP): A multi-purpose marker in hepatocellular carcinoma. Clin. Chim. Acta 2016, 463, 39-44. [CrossRef]

231. Mohammadinejad, A.; Oskuee, R.K.; Eivazzadeh-Keihan, R.; Rezayi, M.; Baradaran, B.; Maleki, A.; Hashemzaei, M.; Mokhtarzadeh, A.; De la Guardia, M. Development of biosensors for detection of alpha-fetoprotein: As a major biomarker for hepatocellular carcinoma. Tractrends Anal. Chem. 2020, 130, 115961. [CrossRef]

232. Li, G.; Li, S.; Wang, Z.; Xue, Y.; Dong, C.; Zeng, J.; Huang, Y.; Liang, J.; Zhou, Z. Label-free electrochemical aptasensor for detection G. of alpha-fetoprotein based on AFP-aptamer and thionin/reduced graphene oxide/gold nanoparticles. Anal. Biochem. 2018, 547, 37-44. [CrossRef]

233. Yang, S.; Zhang, F.; Wang, Z.; Liang, Q. A graphene oxide-based label-free electrochemical aptasensor for the detection of alpha-fetoprotein. Biosens. Bioelectron. 2018, 112, 186-192. [CrossRef]

234. Zhang, B.; Ding, H.; Chen, Q.; Wang, T.; Zhang, K. Prussian blue nanoparticle-labeled aptasensing platform on graphene oxide for voltammetric detection of $\alpha$-fetoprotein in hepatocellular carcinoma with target recycling. Analyst 2019, 144, 4858-4864 [CrossRef] [PubMed]

235. Heiat, M.; Negahdary, M. Sensitive diagnosis of alpha-fetoprotein by a label free nanoaptasensor designed by modified Au electrode with spindle-shaped gold nanostructure. Microchem. J. 2019, 148, 456-466. [CrossRef]

236. Huang, X.; Cui, B.; Ma, Y.; Yan, X.; Xia, L.; Zhou, N.; Wang, M.; He, L.; Zhang, Z. Three-dimensional nitrogen-doped mesoporous carbon nanomaterials derived from plant biomass: Cost-effective construction of label-free electrochemical aptasensor for sensitively detecting alpha-fetoprotein. Anal. Chim. Acta 2019, 1078, 125-134. [CrossRef]

237. Li, J.; Wei, H.; Peng, Y.; Geng, L.; Zhu, L.; Cao, X.-Y.; Liu, C.-S.; Pang, H. A multifunctional self-healing G-PyB/KCl hydrogel: Smart conductive, rapid room-temperature phase-selective gelation, and ultrasensitive detection of alpha-fetoprotein. Chem. Commun. 2019, 55, 7922. [CrossRef] [PubMed]

238. Gu, C.; Peng, Y.; Li, J.; Liu, C.-S.; Pang, H. Controllable synthesis of copper ion guided MIL-96 octadecahedron: Highly sensitive aptasensor toward alpha-fetoprotein. Appl. Mater. Today 2020, 20, 100745. [CrossRef]

239. Abi, A.; Ferapontova, E.E. Electroanalysis of single nucleotide polymorphism by hairpin DNA architectures. Anal. Bioanal. Chem. 2013, 405, 3693-3703. [CrossRef]

240. Gao, T.; Zhi, J.; Mu, C.; Gu, S.; Xiao, J.; Yang, J.; Wang, Z.; Xiang, Y. One-step detection for two serological biomarker species to improve the diagnostic accuracy of hepatocellular carcinoma. Talanta 2018, 178, 89-93. [CrossRef]

241. Yang, X.; Zhao, C.; Zhang, C.; Wen, K.; Zhu, Y. Bi-directionally amplified ratiometric electrochemical aptasensor for the ultrasensitive detection of alpha-fetoprotein. Sens. Actuators B Chem. 2020, 323, 128666. [CrossRef]

242. Han, B.; Dong, L.; Li, L.; Sha, L.; Cao, Y.; Zhao, J. Mild reduction-promoted sandwich aptasensing for simple and versatile detection of protein biomarkers. Sens. Actuators B Chem. 2020, 325, 128762. [CrossRef]

243. Cui, M.; Wang, Y.; Jiao, M.; Jayachandran, S.; Wu, Y.; Fan, X.; Luo, X. Mixed self-assembled aptamer and newly designed zwitterionic peptide as antifouling biosensing interface for electrochemical detection of alpha-fetoprotein. ACS Sens. 2017, 2, 490-494. [CrossRef]

244. Dasgupta, A.; Wahed, A. Clinical Chemistry, Immunology and Laboratory Quality Control; Elsevier Inc.: Amsterdam, The Netherlands, 2014; pp. 229-247.

245. Asad-Ur-Rahman, F.; Saif, M.W. Elevated level of serum carcinoembryonic antigen (CEA) and search for a malignancy: A case report. Cureus 2016, 8, e648. [CrossRef] [PubMed]

246. Fakih, M.G.; Padmanabhan, A. CEA Monitoring in colorectal cancer. What you should know. Oncology 2006, $20,579-587$. [PubMed]

247. Liu, Z.; Wang, Y.; Guo, Y.; Dong, C. Label-free electrochemical aptasensor for carcinoembryonic antigen based on ternary nanocomposite of gold nanoparticles, hemin and graphene. Electroanalysis 2016, 28, 1023-1028. [CrossRef]

248. Wen, W.; Huang, J.-Y.; Bao, T.; Zhou, J.; Xia, H.-X.; Zhang, X.-H.; Wang, S.-F.; Zhao, Y.-D. Increased electrocatalyzed performance through hairpin oligonucleotide aptamer-functionalized gold nanorods labels and graphene-streptavidin nanomatrix: Highly selective and sensitive electrochemical biosensor of carcinoembryonic antigen. Biosens. Bioelectron. 2016, 83, 142-148. [CrossRef] [PubMed] 
249. He, B. Differential pulse voltammetric assay for the carcinoembryonic antigen using a glassy carbon electrode modified with layered molybdenum selenide, graphene, and gold nanoparticles. Microchim. Acta 2017, 184, 229-235. [CrossRef]

250. Si, Z.; Xie, B.; Chen, Z.; Tang, C.; Li, T.; Yang, M. Electrochemical aptasensor for the cancer biomarker CEA based on aptamer induced current due to formation of molybdophosphate. Microchim. Acta 2017, 184, 3215-3221. [CrossRef]

251. Zhou, X.; Guo, S.; Gao, J.; Zhao, J.; Xue, S.; Xu, W. Glucose oxidase-initiated cascade catalysis for sensitive impedimetric aptasensor based on metal-organic frameworks functionalized with $\mathrm{Pt}$ nanoparticles and hemin/G-quadruplex as mimicking peroxidases. Biosens. Bioelectron. 2017, 98, 83-90. [CrossRef]

252. Huang, J.-Y.; Zhao, L.; Lei, W.; Wen, W.; Wang, Y.-J.; Bao, T.; Xiong, H.-Y.; Zhang, X.-H.; Wang, S.-F. A high-sensitivity electrochemical aptasensor of carcinoembryonic antigen based on graphene quantum dots-ionic liquid-nafion nanomatrix and DNAzyme-assisted signal amplification strategy. Biosens. Bioelectron. 2018, 99, 28-33. [CrossRef]

253. Mazloum-Ardakani, M.; Tavakolian-Ardakani, Z.; Sahraei, N.; Moshtaghioun, S.M. Fabrication of an ultrasensitive and selective electrochemical aptasensor to detect carcinoembryonic antigen by using a new nanocomposite. Biosens. Bioelectron. 2019, 129, 1-6. [CrossRef] [PubMed]

254. Hong, F.; Wang, Q.; Wang, W.; Chen, X.; Cao, Y.; Dong, Y.; Gan, N.; Wu, D.; Hu, F. Background signal-free and highly sensitive electrochemical aptasensor for rapid detecting tumor markers with Pb-MOF functionalized dendritic DNA probes. J. Electroanal. Chem. 2020, 861, 113956. [CrossRef]

255. Xu, L.; Zou, L.; Guo, J.; Cao, Y.; Feng, C.; Ye, B. simple "signal-off" electrochemical aptasensor based on aptamer-Cu $\left(\mathrm{PO}_{4}\right)_{2}$ hybrid nanoflowers/graphene oxide for carcinoembryonic antigen detection. ChemElectroChem 2020, 7, 1660-1665. [CrossRef]

256. Yen, Y.-K.; Chao, C.-H.; Yeh, Y.-S. A graphene-PEDOT: PSS modified paper-based aptasensor for electrochemical impedance spectroscopy detection of tumor marker. Sensors 2020, 20, 1372. [CrossRef] [PubMed]

257. Guo, C.; Su, F.; Song, Y.; Hu, B.; Wang, M.; He, L.; Peng, D.; Zhang, Z. Aptamer-templated silver nanoclusters embedded in zirconium metal-organic framework for bifunctional electrochemical and SPR aptasensors toward carcinoembryonic antigen. ACS Appl. Mater. Interfaces 2017, 9, 41188-41199. [CrossRef]

258. Jimenez-Falcao, S.; Parra-Nieto, J.; Pérez-Cuadrado, H.; Martínez-Máñez, R.; Martínez-Ruiz, P.; Villalonga, R. Avidin-gated mesoporous silica nanoparticles for signal amplification in electrochemical biosensor. Electrochem. Commun. 2019, 108, 106556. [CrossRef]

259. Zheng, J.; Wang, J.; Song, D.; Xu, J.; Zhang, M. Electrochemical aptasensor of carcinoembryonic antigen based on concanavalin A-functionalized magnetic copper silicate carbon microtubes and gold-nanocluster-assisted signal amplification. ACS Appl. Nano Mater. 2020, 3, 3449-3458. [CrossRef]

260. Xu, Z.; Han, R.; Liu, N.; Gao, F.; Luo, X. Electrochemical biosensors for the detection of carcinoembryonic antigen with low fouling and high sensitivity based on copolymerized polydopamine and zwitterionic polymer. Sens. Actuators B Chem. 2020, 319, 128253. [CrossRef]

261. Zhang, R.; Liu, L.; Mao, D.; Luo, D.; Cao, F.; Chen, Q.; Chen, J. Construction of electrochemical aptasensor of carcinoembryonic antigen based on toehold-aided DNA recycling signal amplification. Bioelectrochemistry 2020, 133, 107492. [CrossRef]

262. Cheng, H.; Xu, L.; Zhang, H.; Yu, A.; Lai, G. Enzymatically catalytic signal tracing by a glucose oxidase and ferrocene dually functionalized nanoporous gold nanoprobe for ultrasensitive electrochemical measurement of a tumor biomarker. Analyst 2016, 141, 4381-4387. [CrossRef]

263. Park, J.W.; Na, W.; Jang, J. One-pot synthesis of multidimensional conducting polymer nanotubes for superior performance field-effect transistor-type carcinoembryonic antigen biosensors. RSC Adv. 2016, 6, 14335-14343. [CrossRef]

264. Wang, P.; Wan, Y.; Deng, S.; Yang, S.; Su, Y.; Fan, C.; Aldalbahi, A.; Zuo, X. Aptamer-initiated on-particle template-independent enzymatic polymerization (aptamer-OTEP) for electrochemical analysis of tumor biomarkers. Biosens. Bioelectron. 2016, 86, 536-541. [CrossRef]

265. Zhou, X.; Xue, S.; Jing, P.; Xu, W. A sensitive impedimetric platform biosensing protein: Insoluble precipitates based on the biocatalysis of manganese (III) meso-tetrakis (4-N-methylpyridiniumyl)-porphyrinin in HCR-assisted dsDNA. Biosens. Bioelectron. 2016, 86, 656-663. [CrossRef]

266. Taghdisi, S.M.; Danesh, N.M.; Ramezani, M.; Emrani, A.S.; Abnous, K. A novel electrochemical aptasensor for carcinoembryonic antigen detection based on target-induced bridge assembly. Electroanalysis 2018, 30, 1734-1739. [CrossRef]

267. Wang, Q.-L.; Cui, H.-F.; Song, X.; Fan, S.-F.; Chen, L.-L.; Li, M.-M.; Li, Z.-Y. A label-free and lectin-based sandwich aptasensor for detection of carcinoembryonic antigen. Sens. Actuators B Chem. 2018, 260, 48-54. [CrossRef]

268. He, L.; Li, Z.; Guo, C.; Hu, B.; Wang, M.; Zhang, Z.; Du, M. Bifunctional bioplatform based on NiCo Prussian blue analogue: Label-free impedimetric aptasensor for the early detection of carcino-embryonic, antigen and living cancer cells. Sens. Actuators $B$ Chem. 2019, 298, 126852. [CrossRef]

269. Liu, Z.; Lei, S.; Zou, L.; Li, G.; Xu, L.; Ye, B. A label-free and double recognition-amplification novel strategy for sensitive and accurate carcinoembryonic antigen assay. Biosens. Bioelectron. 2019, 131, 113-118. [CrossRef] [PubMed]

270. Paniagua, G.; Villalonga, A.; Eguílaz, M.; Vegas, B.; Parrado, C.; Rivas, G.; Díez, P.; Villalonga, R. Amperometric aptasensor for carcinoembryonic antigen based on the use of bifunctionalized Janus nanoparticles as biorecognition signaling element. Anal. Chim. Acta 2019, 1061, 84-91. [CrossRef] [PubMed] 
271. Xu, L.; Liu, Z.; Lei, S.; Huang, D.; Zou, L.; Ye, B. A sandwich-type electrochemical aptasensor for the carcinoembryonic antigen via biocatalytic precipitation amplification and by using gold nanoparticle composites. Microchim. Acta 2019, 186, 473. [CrossRef] [PubMed]

272. Liu, C.; Liu, X.; Qin, Y.; Deng, C.; Xiang, J. A simple regenerable electrochemical aptasensor for the parallel and continuous detection of biomarkers. RSC Adv. 2016, 6, 58469-58476. [CrossRef]

273. Xiang, J.; Pi, X.; Chen, X.; Xiang, L.; Yang, M.; Ren, H.; Shen, X.; Qi, N.; Deng, C. Integrated signal probe based aptasensor for dual-analyte detection. Biosens. Bioelectron. 2017, 96, 268-274. [CrossRef] [PubMed]

274. Zhao, Y.; Yang, Y.; Sun, Y.; Cui, L.; Zheng, F.; Zhang, J.; Song, Q.; Xu, C. Shell-encoded Au nanoparticles with tunable electroactivity for specific dual disease biomarkers detection. Biosens. Bioelectron. 2018, 99, 193-200. [CrossRef]

275. Wang, Y.; Luo, J.; Liu, J.; Sun, S.; Xiong, Y.; Ma, Y.; Yan, S.; Yang, Y.; Yin, H.; Cai, X. Label-free microfluidic paper-based electrochemical aptasensor for ultrasensitive and simultaneous multiplexed detection of cancer biomarkers. Biosens. Bioelectron. 2019, 136, 84-90. [CrossRef]

276. Wang, W.; Wang, Q.; Xie, H.; Wu, D.; Gan, N. A universal assay strategy for sensitive and simultaneous quantitation of multiplex tumor markers based on the stirring rod-immobilized $\mathrm{DNA}-\mathrm{LaMnO} 3$ perovskite-metal ions encoded probes. Talanta 2021, 222, 121456. [CrossRef]

277. Fan, J.; Tang, Y.; Yang, W.; Yu, Y. Disposable multiplexed electrochemical sensors based on electro-triggered selective immobilization of probes for simultaneous detection of DNA and proteins. J. Mater. Chem. B 2020, 8, 7501-7510. [CrossRef]

278. Marko, N.F.; Weil, R.J.; Toms, S.A. Nanotechnology in proteomics. Expert Rev. Proteom. 2007, 4, 617-626. [CrossRef] [PubMed]

279. Ehdaie, B. Application of nanotechnology in cancer research: Review of progress in the National Cancer Institute's Alliance for nanotechnology. Int. J. Biol. Sci. 2007, 3, 108-110. [CrossRef] [PubMed]

280. Available online: https://www.pointofcare.abbott/int/en/offerings/istat (accessed on 2 December 2020).

281. Zhang, Y.; Figueroa-Miranda, G.; Wu, C.; Willbold, D.; Offenhäusser, A.; Mayer, D. Electrochemical dual-aptamer biosensors based on nanostructured multielectrode arrays for the detection of neuronal biomarkers. Nanoscale 2020, 12, 16501-16513. [CrossRef] [PubMed]

282. Malhotra, R.; Patel, V.; Chikkaveeraiah, B.V.; Munge, B.S.; Cheong, S.C.; Zain, R.B.; Abraham, M.T.; Dey, D.K.; Gutkind, J.S.; Rusling, J.F. Ultrasensitive detection of cancer biomarkers in the clinic by use of a nanostructured microfluidic array. Anal. Chem. 2012, 84, 6249-6255. [CrossRef]

283. Ilyas, A.; Asghar, W.; Allen, P.B.; Duhon, H.; Ellington, A.D.; Iqbal, S.M. Electrical detection of cancer biomarker using aptamers with nanogap break-junctions. Nanotechnology 2012, 23, 275502. [CrossRef]

284. Liu, D.; Wang, J.; Wu, L.; Huang, Y.; Zhang, Y.; Zhu, M.; Wang, Y.; Zhu, Z.; Yang, C. Trends in miniaturized biosensors for point-of-care testing. Tractrends Anal. Chem. 2020, 122, 115701. [CrossRef] 